\title{
13. ISOTOPIC EVIDENCE FOR THE ORIGIN OF BONINITES AND RELATED ROCKS DRILLED IN THE IZU-BONIN (OGASAWARA) FOREARC, LEG $125^{1}$
}

\author{
Julian A. Pearce, ${ }^{2}$ Matthew F. Thirlwall, ${ }^{3}$ Gerry Ingram, ${ }^{3}$ Bramley J. Murton, ${ }^{2,4}$ Richard J. Arculus, ${ }^{5}$ \\ and Sieger R. van der Laan ${ }^{6}$
}

\begin{abstract}
Twenty-six samples representing the wide range of lithologies (low- and intermediate-Ca boninites and bronzite andesites, high-Ca boninites, basaltic andesites-rhyolites) drilled during Leg 125 at Sites 782 and 786 on the Izu-Bonin outer-arc high have been analyzed for $\mathrm{Sr}, \mathrm{Nd}$, and $\mathrm{Pb}$ isotopes. $\mathrm{Nd}-\mathrm{Sr}$ isotope covariations show that most samples follow a trend parallel to a line from Pacific MORB mantle (PMM) to Pacific Volcanogenic sediment (PVS) but displaced slightly toward more radiogenic Sr. $\mathrm{Pb}$ isotope covariations show that all the Eocene-Oligocene samples plot along the Northern Hemisphere Reference Line, indicating little or no $\mathrm{Pb}$ derived from subducted pelagic sediment in their source. Two young basaltic andesite clasts within sediment do have a pelagic sediment signature but this may have been gained by alteration rather than subduction. In all isotopic projections, the samples form consistent groupings: the tholeiites from Site 782 and Hole 786A plot closest to PMM, the boninites and related rocks from Sites 786B plot closest to PVS, and the boninite lavas from Hole 786A and late boninitic dikes from Hole 786B occupy an intermediate position. Isotope-trace element covariations indicate that these isotopic variations can be explained by a three-component mixing model. One component (A) has the isotopic signature of PMM but is depleted in the more incompatible elements. It is interpreted as representing suboceanic mantle lithosphere. A second component (B) is relatively radiogenic $\left(\varepsilon \mathrm{Nd}=\mathrm{ca} 4-6 ;{ }^{206} \mathrm{~Pb} /{ }^{204} \mathrm{~Pb}=\mathrm{ca} 19.0-19.3 ; \varepsilon \mathrm{Sr}=\mathrm{ca}-10\right.$ to -6$)$ ). Its trace element pattern has, among other characteristics, a high $\mathrm{Zr} / \mathrm{Sm}$ ratio, which distinguishes it from the "normal" fluid components associated with subduction and hotspot activity. There are insufficient data at present to tie down its origin: probably it was either derived from subducted lithosphere or volcanogenic sediment fused in amphibolite facies; or it represents an asthenospheric melt component that has been fractionated by interaction with amphibole-bearing mantle. The third component (C) is characterized by high contents of $\mathrm{Sr}$ and high $\varepsilon \mathrm{Sr}$ values and is interpreted as a subducted fluid component. The mixing line on a diagram of $\mathrm{Zr} / \mathrm{Sr}$ against $\varepsilon \mathrm{Sr}$ suggests that component $\mathrm{C}$ may have enriched the lithosphere (component $\mathrm{A}$ ) before component $\mathrm{B}$. These components may also be present on a regional basis but, if so, may not have had uniform compositions. Only the boninitic series from nearby Chichijima would require an additional, pelagic sediment component. In general, these results are consistent with models of subduction of ridges and young lithosphere during the change from a ridge-transform to subduction geometry at the initiation of subduction in the Western Pacific.
\end{abstract}

\section{INTRODUCTION}

During Ocean Drilling Program Leg 125, scientists drilled two sites (782 and 786) on the Izu-Bonin (Ogasawara) outer-arc high (Fig. 1). Site 782 was originally designated as the main site for deep basement drilling. Two adjacent holes were drilled. Hole $782 \mathrm{~A}$ was drilled to $476.8 \mathrm{mbsf}$ (meters below seafloor), recovering $409.2 \mathrm{~m}$ of sediments and $67.6 \mathrm{~m}$ of basement. Hole 782B recovered just $9.6 \mathrm{~m}$ of basement between 459.3 and $468.9 \mathrm{mbsf}$. The second site, Site 786, provided a deep, forearc crustal section. Two adjacent holes also were drilled at this site. Hole 786A was drilled to $167 \mathrm{mbsf}$ with an extended core barrel (XCB), recovering $125 \mathrm{~m}$ of forearc sediment and about $42 \mathrm{~m}$ of basement. Hole 786B was drilled with a rotary core barrel (RCB), recovering a further $666 \mathrm{~m}$ of basement between 162.5 and $828.6 \mathrm{mbsf}$.

The rocks recovered from these sites have been studied in terms of their stratigraphy and major element contents (Arculus et al., this

\footnotetext{
${ }^{1}$ Fryer, P., Pearce, J. A., Stokking, L., et al., 1991. Proc. ODP, Sci. Results, 125 : College Station, TX (Ocean Drilling Program).

2 Department of Geological Sciences, University of Durham, Durham DH1 3LE, United Kingdom.

${ }^{3}$ Department of Geology, RHBNC, Egham Hill, Egham, Surrey, TW20 OEX, United Kingdom.

${ }^{4}$ Institute of Oceanographic Sciences, Wormley, Godalming, Surrey GU8 SUB, United Kingdom.

${ }_{5}^{5}$ Department of Geology, University of New England, Armidale, N.S.W. 2351, Australia.

${ }^{6}$ Department of Geology and Geophysics, University of Hawaii, Honolulu, Hawaii 96822, USA.
}

volume), their structure (Lagabrielle et al., this volume), their age (Mitchell et al., this volume), their petrography and phase relations (van der Laan et al., this volume) and their trace element characteristics (Murton et al., this volume). Site 782 yielded a small number of clasts of tholeiitic andesites, dacites, and rhyolites which have been grouped as a single lithostratigraphic unit. At Site 786, however, drilling penetrated a complex boninitic volcanic edifice with a welldefined stratigraphy (Fig. 2). The top of the edifice, a volcanic breccia, was drilled at Hole 786A. The remainder of the edifice was drilled at Hole 786B. In its upper and middle parts, the edifice comprises a series of lavas, dikes, breccias, and pyroclastic flows of intermediate$\mathrm{Ca}$ boninite, intermediate-Ca bronzite andesite, and andesite-rhyolite composition. These overlie a series of low-Ca boninite pillow lavas and hyaloclastite breccias which in turn overlie a swarm of low-Ca bronzite andesite dikes. This basal sequence is cut by feeder dikes to the main part of the edifice. This volcanic structure subsequently was intruded by a series of dikes and/or sills of intermediate- to high-Ca boninite composition. The edifice has been subdivided into 35 lithostratigraphic units (Unit IV-0 in Hole 786A and Units IV1-IV34 in Hole 786B).

$\mathrm{K}-\mathrm{Ar}$ isochrons suggest an age of $41.3 \pm 0.5 \mathrm{Ma}$ (middle-late Eocene) for the main constructional phase of the edifice and an age of $34.6 \pm 0.7 \mathrm{Ma}$ (earliest Oligocene) for the later intrusive phase (Mitchell et al., this volume). A number of ages between 17 and $9 \mathrm{Ma}$ may be evidence for one or more subsequent intrusive episodes or may indicate that alteration of the basement continued for a long period after its formation. The tholeiitic lavas at Site 782 gave no consistent age, although the oldest age of $36 \mathrm{Ma}$ suggests that these were broadly contemporaneous with the boninite series volcanics drilled at Site 786. 


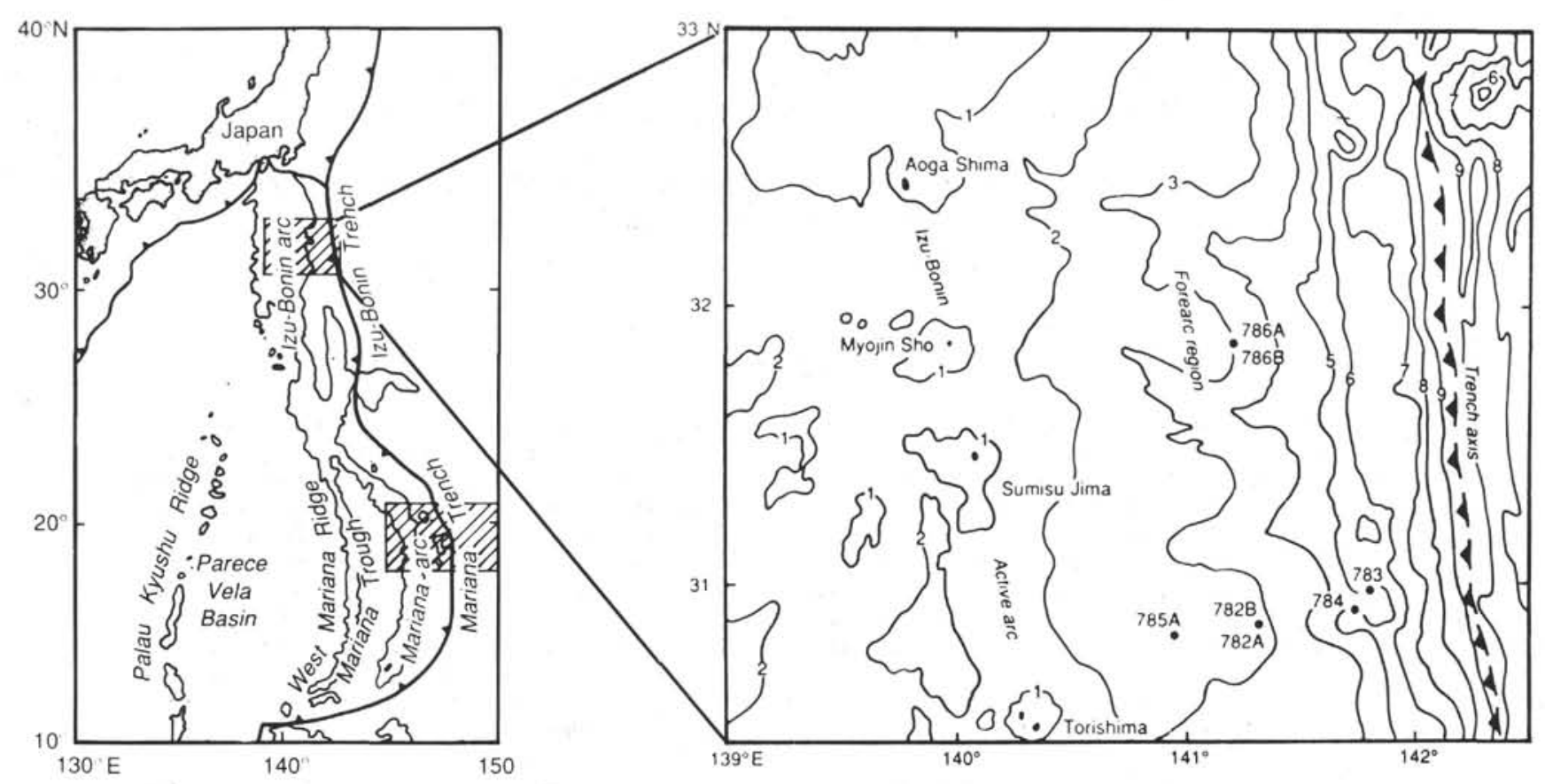

Figure 1. Regional setting of the Izu-Bonin (Ogasawara) and Mariana forearc terranes and location of ODPLeg 125 outer-arc high Sites 782 and 786. Contours are in kilometers below sea level.

The aims of this study are to use isotopic data to characterize the sources of the igneous rocks recovered at these two sites and to examine the results in the light of published isotope data from the Izu-Bonin-Mariana forearc terrane.

\section{SAMPLE SELECTION}

Twenty-six samples from the various lithostratigraphic units in Sites 782 and 786 were analyzed for $\mathrm{Sr}, \mathrm{Nd}$, and $\mathrm{Pb}$ isotopes. Sample selection was carried out mainly during the leg from the most homogeneous and apparently least altered of the rock types recovered. The pervasive alteration meant, however, that no truly fresh rocks could be sampled. Classification of the samples chosen was carried out on the basis of the $\mathrm{MgO}-\mathrm{SiO}_{2}$ and $\mathrm{CaO}-\mathrm{SiO}_{2}$ covariation diagrams described in Arculus et al. (this volume) and reproduced in Figure 3. This figure also demonstrates that the samples selected for isotope analysis are representative of the range of compositions encountered at the two sites. For convenience of presentation, the samples have been clustered into seven groups in this and subsequent diagrams on the basis of rock type, location and age. These groups are as follows:

1. low-Ca boninites and low-Ca bronzite andesites from the base of the $41 \mathrm{Ma}$ edifice in Hole 786B (the 786B-LCB group);

2 . intermediate- $\mathrm{Ca}$ boninites and intermediate-Ca bronzite andesites from the lower/middle to upper part of the 41 Ma edifice in Hole 786B (the 786B-ICB group);

3. andesites, dacites, and rhyolites from the middle-upper part of the $41 \mathrm{Ma}$ edifice in Hole 786B (the 786B-ADR group);

4. intermediate- and high-Ca boninites forming the late (34-35 Ma) dikes or sills in Hole 786B (the 786B-late dike group);

5. intermediate-Ca boninites from the basement in Hole 786A (the 786A-ICB group);

6. basaltic andesites from intra-sediment clasts in Hole 786A (the 786A-BA group);
7. tholeiitic andesites and dacites from the basement in Holes 786A and 786B (the 782-ThAD group).

The mineralogies and ages of the samples are relevant to the treatment of the isotopic data, and thus are described briefly below.

1. 786B-LCB group. Samples of low-Ca boninite pillow lavas were taken from Cores 57R-4 and 62R-3 for isotopic analysis. Both samples contain $5 \%-10 \%$ of phenocrysts, the sample from Core $57 \mathrm{R}-4$ containing olivine and orthopyroxene, that from Core 62R-3 containing orthopyroxene only. Both have a cryptocrystalline to glassy groundmass. Both rocks are very altered, in common with all samples from this group. Orthopyroxenes and glass are largely replaced by brown clay, olivine is replaced by serpentine, oxide, and calcite, and vesicles and small fractures contain zeolite and brown clay. $\mathrm{K}-\mathrm{Ar}$ dating gave an age of $38.4 \pm 2.3$ $\mathrm{Ma}$ for $57 \mathrm{R}-4$, close to the $41 \mathrm{Ma}$ isochron taken as the edifice age.

The bronzite andesite dike, taken from Core 70R-1, has abundant phenocrysts of orthopyroxene, clinopyroxene, and, less commonly, plagioclase in a fine-grained groundmass of plagioclase laths, clinopyroxene, and opaque minerals. Orthopyroxene and most of the groundmass are replaced by chlorite, clay minerals, and carbonate. $\mathrm{K}$-Ar dating gave an age of $38.7 \pm 0.8$, close to the $41 \mathrm{Ma}$ isochron.

2. 786B-ICB group. Intermediate-Ca boninites were sampled from Core 51R-1, in a breccia unit just above the low-Ca boninite basement, and from Core 11R-1, in a polymict breccia near the top of the sequence. Both rocks carry abundant phenocrysts of plagioclase, orthopyroxene, and clinopyroxene in a groundmass of plagioclase, pyroxenes, an opaque phase, and interstitial glass and contain about $15 \%$ of unfilled vesicles. The orthopyroxene phenocrysts and the matrix glass are replaced by brown clays. Both samples are vesicular, the vesicles from the sample in Core 11R-1 having a green chloritic lining. The $\mathrm{K}-\mathrm{Ar}$ age of the sample from $51 \mathrm{R}-1$ is $33.6 \pm 0.6 \mathrm{Ma}$, interpreted as having been reset from a $41 \mathrm{Ma}$ age by the $34-35 \mathrm{Ma}$ dike intrusion episode. The age of the sample from Core 11R-1 is 25.7 $\pm 1.2 \mathrm{Ma}$, again a reset age. 
Intermediate-Ca bronzite andesites are taken from breccia units in Cores IR-1 and 30R-1. They are both highly plagioclase-clinopyroxeneorthopyroxene phyric with rare olivine in the former. Groundmasses are dominated by plagioclase microliths and pyroxenes with interstitial glass. The glass, and many orthopyroxene crystals, have been replaced by clay minerals. A sample close to that from Core $1 \mathrm{R}-1$ and the sample from Core 30R-1 gave ages of $41.0 \pm 1.1$ and $39.8 \pm 1.3$ Ma respectively.

3. 786B-ADR group. Andesites were sampled at four localities in the top to middle part of Hole 786B, in Cores 8R-1, 19R-1, 21R-1, and 49R-4. All rocks contained abundant phenocrysts of plagioclase and clinopyroxene and rare orthopyroxene, in groundmasses dominated by plagioclase and opaque phases with interstitial glass. The latter is now altered to clay minerals, totally in the samples from Cores 8R-1 and 21R-1 (129-131 cm) and partially in samples from Cores 19R-1 and 49R-4. The sample from Core 49R-4 also contains rare, replaced olivine phenocrysts and more clinopyroxene in the groundmass. K-Ar dating gave reset ages of $9.2 \pm 0.4$ and $16.7 \pm$ $0.4 \mathrm{Ma}$ for the samples from Cores $8 \mathrm{R}-1$ and $21 \mathrm{R}-1$ respectively.

Dacites and rhyolites were sampled from lavas in the upper part of the Hole 786B (from Cores 21R-1 and 35R-1) and from dikes within the low-Ca boninite series basement (from Cores 63R-2 and 66R-1). The lava samples are highly vesicular and contain phenocrysts of plagioclase and clinopyroxene in a matrix similar to that of the andesites. The dikes may have had a similar mineralogy but have been intensely altered to an assemblage dominated by clay minerals and chlorite. K-Ar dating of a dike in Core 66R-2 gave an age of $41.3 \pm 0.8 \mathrm{Ma}$.

4. 786B-late dike group. Samples of four late dikes have been taken from Hole 786B, from Cores 5R-2, 21R-2, 40R-2, and 67R-1. Two samples (from Cores 21R-2 and 67R-1) classify as intermediate-Ca boninite. They are olivine-orthopyroxene-clinopyroxene phyric in a fine-grained groundmass of plagioclase, clinopyroxene, an opaque phase, and cryptocrystalline-glassy groundmass. The other two samples (from Cores $5 \mathrm{R}-2$ and 40R-2) classify as high-Ca boninites. They are olivine-orthopyroxene and olivine-orthopyroxene-clinopyroxene phyric, respectively, in a groundmass similar to that of the intermediate-Ca boninites. All samples contain a small proportion of unfilled vesicles. Variable clay mineral alteration of the glassy groundmass and of many olivine and orthopyroxene phenocrysts is common to all samples. Olivine phenocrysts in the sample from Core 21R-2 have been replaced by carbonate, resulting in loss of $\mathrm{Mg}$ and gain in $\mathrm{Ca}$. The $\mathrm{MgO}$ and $\mathrm{CaO}$ values in Table 1 have been adjusted to show the pre-carbonation composition.

All four samples have been dated by the K-Ar method. Those from Cores 21R-2 and 40R-2 both plot on the $34-5 \mathrm{Ma}$ isochron. Core $67 \mathrm{R}-1$ gave an older age of $41 \pm 1.0 \mathrm{Ma}$ and would have been classified with the 786B-ICB group were it not for its isotope and trace element composition (see later). A sample in the same unit as Core 5R-2 gave an age of $17.3 \pm 0.9 \mathrm{Ma}$. It is not clear at present whether this unit represents a separate intrusive phase or whether it had an older (34-35 Ma) age that has been reset.

5.786A-ICB group. The intermediate-Ca boninite samples were taken from near the base of Hole 786A, from Cores 16X-1 and 17X-1. They are both moderately vesicular and contain phenocrysts of olivine, orthopyroxene, clinopyroxene, and rare plagioclase in a matrix of plagio-clase, clinopyroxene, opaque minerals, and altered glass. The sample from Core $16 \mathrm{X}-1$ gave a $\mathrm{K}-\mathrm{Ar}$ age of $15.3 \pm 1.0$, taken as reset in view of its Eocene biostratigraphic age. In the absence of more definitive data, ages of 35 Ma have been assumed for these samples.

6. $786 A-B A$ group. Sample $12 \mathrm{X}-1$ and $6 \mathrm{X}-5$ represent the basaltic andesite clasts recovered from Units I and III of the sediments overlying the basement at Site 786A. Both contain clinopyroxene and plagioclase microliths in an altered glassy matrix. The sample from Core $12 \mathrm{X}-1$ gave a $\mathrm{K}-\mathrm{Ar}$ age of $9.3 \pm 0.4 \mathrm{Ma}$. This could be a true age if the sample is from a dike or sill rather than a lava or if the enclosing late Eocene sediments have been reworked. More probably, however, the age has been reset. An arbitrary age of $17 \mathrm{Ma}$ is taken for the isotope calculations. The sample from Core $6 \mathrm{X}-5$ has not been dated but must be equal to or less than its stratigraphic age of upper Middle Miocene (Fryer, Pearce, Stokking, et al., 1990). An age of 10 Ma has been assumed for this sample.

7. Site 782-ThAD group. Three samples were analyzed from Hole 782A, andesites from Cores 49X-CC and 50X and a dacite from Core $45 \mathrm{X}-1$. These samples are all highly vesicular and contain plagioclase and clinopyroxene phenocrysts in an altered (clay-rich) glassy matrix. The samples from Cores $45 \mathrm{X}-1$ and $50 \mathrm{X}-1$ have been dated, giving ages of $18.1 \pm 0.6$ and $30.7 \pm 1.3$ Ma respectively. Another sample from Site 782 gave an age of $36 \pm 1.1 \mathrm{Ma}$, probably closer to the real age of the basement at this site.

\section{ANALYTICAL TECHNIQUES}

All samples chosen for isotope analysis have been analyzed for major elements and 32 trace elements, including those relevant to the isotope systems (Table 1). The major element data are taken from Arculus et al. (this volume). Trace element analyses were carried out by ICP-MS at the University of Durham, using duplicate preparations to improve the quality of the data. Because the samples were prepared on board the JOIDES Resolution using a tungsten carbide tema mill, they have experienced $\mathrm{Ta}, \mathrm{Nb}$, and $\mathrm{Hf}$ contamination. The concentrations of these elements have therefore been obtained by analyses of adjacent samples crushed using an agate tema mill. These analyses were carried out both by INAA and ICP-MS. The data obtained for this paper are also incorporated into the full trace element data set in Murton et al. (this volume), to which the reader is referred for details of the analytical techniques. Note that there may be slight discrepancies between Table 1 and the equivalent table in Murton et al. (this volume) because of small differences in weighting duplicate analyses. Any differences should be within analytical error, which is shown as error bars on all diagrams that use trace elements. Many of the same samples have been dated by the $\mathrm{K}-\mathrm{Ar}$ method. These dates have been summarized above and are discussed further in Mitchell et al. (this volume).

The isotopic analyses were carried out at Royal Holloway and Bedford New College (RHBNC), London, using a VG354 fivecollector mass-spectrometer. Multidynamic data collection was used for $\mathrm{Sr}$ and $\mathrm{Nd}$ and static data collection for $\mathrm{Pb}$. Most $\mathrm{Nd}$ analyses were determined as $\mathrm{NdO}^{+}$on single $\mathrm{Re}$ filaments using the technique of Thirlwall (1991a). Conventional ion exchange methods were used to effect element separations. The data are presented in Table 2.

${ }^{87} \mathrm{Sr}{ }^{\beta 6} \mathrm{Sr}$ ratios were normalized by exponential law to ${ }^{86} \mathrm{Sr} /{ }^{88} \mathrm{Sr}=$ 0.1194. SRM987 gave a mean value of $0.710244 \pm 23(2$ s.d., $\mathrm{N}=48$ ) over the period of analysis. Because of alteration, all except the freshest and most acidic samples were subjected to heavy leaching in $6 \mathrm{~N} \mathrm{HCl}$ for several hours at $180^{\circ} \mathrm{C}$ followed by careful rinsing with pure water. ${ }^{143} \mathrm{Nd} /{ }^{144} \mathrm{Nd}$ ratios were normalized to ${ }^{146} \mathrm{Nd} /{ }^{144} \mathrm{Nd}=0.7219$. Values of $0.511420 \pm 9(2$ s.d., $N=23)$ were obtained for a laboratory standard over the period of analysis, equivalent to a value for the La Jolla standard of 0.511857 (Thirlwall, 1991a,b). $\mathrm{Pb}$ isotope ratios were corrected for mass fractionation by ca $0.11 \% / \mathrm{amu}$ by normalization to SRM981. Internal errors are estimated at better than $0.005 \% / a m u(2$ s.e. $)$ and reproducibility at better than $0.05 \%$ /amu ( 2 s.d.).

Sr isotope measured ratios for the leached samples were treated as equivalent to initial values, following optical examination which showed that the residue from leaching was dominated by clinopyroxene. Unleached samples were corrected using $\mathrm{Rb}$ and $\mathrm{Sr}$ analyses from Table 1 assuming that alteration did not post-date significantly the eruption age. Nd analyses were converted to initial ratios using $\mathrm{Sm}$ and $\mathrm{Nd}$ analyses from Table 1, again assuming that alteration and eruption ages were similar. Epsilon-values for both elements, also given in Table 1, are used as the basis for isotope comparisons. They are based on present-day bulk earth compositions of ${ }^{143} \mathrm{Nd} /{ }^{144} \mathrm{Nd}=0.512637,{ }^{147} \mathrm{Sm} /{ }^{144} \mathrm{Nd}=0.1967,{ }^{87} \mathrm{Sr} /{ }^{\beta 6} \mathrm{Sr}=0.7047$, and ${ }^{87} \mathrm{Rb} /{ }^{86} \mathrm{Sr}=0.0847$ (Hawkesworth and Norry, 1983).

Lead isotopes have been reported as both measured and initial ratios in Table 2 . Because of the need to compare lead isotopes with 
Table 1. Major and trace element analyses of samples chosen for isotopic analysis. For details, see the text.

\begin{tabular}{|c|c|c|c|c|c|c|c|c|c|c|c|c|c|c|}
\hline Hole & $786 \mathrm{~B}$ & $786 \mathrm{~B}$ & $786 \mathrm{~B}$ & $786 \mathrm{~B}$ & $768 \mathrm{~B}$ & $786 \mathrm{~B}$ & $786 \mathrm{~B}$ & $786 \mathrm{~B}$ & $786 \mathrm{~B}$ & $786 B$ & $786 \mathrm{~B}$ & $786 \mathrm{~B}$ & $786 \mathrm{~B}$ & $786 \mathrm{~B}$ \\
\hline Core & $57 \mathrm{R}-4$ & $62 R-3$ & $70 \mathrm{R}-1$ & 51R-1 & $11 \mathrm{R}-1$ & $30 \mathrm{R}-1$ & 1R-1 & $8 \mathrm{R}-1$ & $19 \mathrm{R}-1$ & $49 \mathrm{R}-4$ & $21 \mathrm{R}-1$ & $35 \mathrm{R}-1$ & 21R-1 & $66 \mathrm{R}-1$ \\
\hline Interval $(\mathrm{cm})$ & $69-77$ & $40-42$ & $68-73$ & $51-55$ & $122-126$ & $29-31$ & $61-64$ & $45-47$ & $91-94$ & $32-37$ & $26-30$ & $73-76$ & $129-131$ & $88-90$ \\
\hline Unit & IV -27 & IV -27 & IV-33 & IV-26 & IV-4 & IV-13 & IV-I & IV-3 & IV-6 & IV-24 & IV-6 & IV-20 & IV-8 & IV-29 \\
\hline Magma type & LCB & LCB & LCBrzA & $\mathrm{ICB}^{\mathrm{a}}$ & ICB & ICBrzA & ICBrzA & $\mathrm{A}^{\mathrm{a}}$ & A & A & $\mathrm{A}^{\mathrm{a}}$ & D & $\mathrm{R}$ & $\mathbf{R}$ \\
\hline $\mathrm{SiO}_{2}$ & 50.28 & 53.47 & 58.44 & 53.25 & 53.64 & 56.03 & 60.11 & 54.37 & 58.13 & 58.34 & 56.85 & 64.80 & 66.90 & 68.95 \\
\hline $\mathrm{TiO}_{2}$ & 0.21 & 0.20 & 0.23 & 0.22 & 0.22 & 0.21 & 0.21 & 0.31 & 0.29 & 0.31 & 0.36 & 0.28 & 0.28 & 0.26 \\
\hline $\mathrm{Al}_{2} \mathrm{O}_{3}$ & 10.90 & 12.05 & 11.43 & 12.74 & 12.89 & 12.20 & 12.39 & 17.48 & 16.25 & 15.03 & 16.95 & 14.72 & 12.62 & 13.41 \\
\hline $\mathrm{Fe}_{2} \mathrm{O}_{3}$ & 7.39 & 8.47 & 6.15 & 8.49 & 7.62 & 6.98 & 7.03 & 7.76 & 7.49 & 7.00 & 7.70 & 5.39 & 3.49 & 4.07 \\
\hline $\mathrm{MnO}$ & 0.13 & 0.13 & 0.13 & 0.16 & 0.14 & 0.09 & 0.11 & 0.12 & 0.12 & 0.13 & 0.10 & 0.04 & 0.07 & 0.08 \\
\hline $\mathrm{MgO}$ & 12.19 & 13.04 & 7.40 & 12.36 & 10.88 & 6.52 & 7.80 & 3.98 & 3.57 & 3.62 & 1.85 & 2.36 & 0.31 & 0.82 \\
\hline $\mathrm{CaO}$ & 4.90 & 5.27 & 4.95 & 7.78 & 6.50 & 9.83 & 6.09 & 7.69 & 7.14 & 7.29 & 6.56 & 5.00 & 2.30 & 2.26 \\
\hline $\mathrm{Na}_{2} \mathrm{O}$ & 2.88 & 3.19 & 3.23 & 2.69 & 2.73 & 2.59 & 3.06 & 3.61 & 3.13 & 3.10 & 3.90 & 3.82 & 3.99 & 3.70 \\
\hline $\mathrm{K}_{2} \mathrm{O}$ & 0.48 & 0.67 & 0.20 & 0.26 & 0.42 & 0.87 & 0.51 & 0.65 & 0.71 & 0.73 & 0.85 & 0,69 & 2.05 & 3.12 \\
\hline $\mathrm{P}_{2} \mathrm{O}_{5}$ & 0.01 & 0.03 & 0.04 & 0.24 & 0.01 & 0.02 & 0.02 & 0.05 & 0.04 & 0.04 & 0.31 & 0.08 & 0.07 & 0.08 \\
\hline LOI & 10.50 & 4.33 & 4.66 & 2.01 & 2.80 & 4.23 & 2.19 & 2.71 & 2.34 & 2.89 & 2.91 & 1.23 & 6.50 & 2.36 \\
\hline Total & 99.87 & 100.85 & 96.86 & 100.20 & 97.85 & 99.57 & 99.52 & 98.73 & 99.21 & 98.48 & 98.34 & 98.41 & 98.58 & 99.11 \\
\hline Sc & 30.7 & 29.0 & 27.6 & 28.7 & 29.2 & 31.0 & 24.9 & 25.0 & 20.8 & 25.0 & 21.8 & 20.4 & 11.4 & 11.8 \\
\hline $\mathrm{Cr}$ & 1113 & 1036 & 670 & 764 & 543 & 374 & 384 & 12 & 12 & 113 & 11 & 51 & 4 & 33 \\
\hline V & 134 & 166 & 148 & 220 & 171 & 132 & 177 & 236 & 226 & 244 & 190 & 152 & 24 & 31 \\
\hline $\mathrm{Ni}$ & 281 & 306 & 202 & 196 & 157 & 126 & 115 & 41 & 22 & 39 & 17 & 26 & 6 & 9 \\
\hline Co & 41.6 & 45.0 & 32.0 & 36.5 & 36.3 & 30.9 & 29.1 & 24.5 & 19.1 & 22.4 & 11.3 & 13.9 & 7.9 & 5.6 \\
\hline $\mathrm{Cu}$ & 18 & 60 & 70 & 42 & 40 & 29 & 66 & 68 & 83 & 89 & 80 & 34 & 68 & 50 \\
\hline $\mathrm{Zn}$ & 61 & 63 & 77 & 69 & 71 & 51 & 55 & 73 & 72 & 58 & 72 & 48 & 49 & 92 \\
\hline $\mathrm{Rb}$ & 7.0 & 6.4 & 1.5 & 4.3 & 5.7 & 20.3 & 5.8 & 8.5 & 7.7 & 10.7 & 11.0 & 9.1 & 34.2 & 29.0 \\
\hline $\mathrm{Sr}$ & 115 & 107 & 144 & 156 & 165 & 193 & 166 & 220 & 215 & 186 & 238 & 222 & 151 & 104 \\
\hline $\mathrm{Y}$ & 7.4 & 7.2 & 8.9 & 16.9 & 5.1 & 5.1 & 6.7 & 13.1 & 9.2 & 9.7 & 20.7 & 10.1 & 11.8 & 10.7 \\
\hline $\mathrm{Zr}$ & 36 & 35 & 45 & 37 & 40 & 36 & 45 & 50 & 49 & 46 & 58 & 62 & 83 & 81 \\
\hline $\mathrm{Nb}$ & 0.70 & 0.53 & 0.65 & 0.62 & 0.62 & 0.52 & 0.70 & 0.77 & 0.74 & 0.72 & 0.90 & 1.03 & 1.08 & 0.98 \\
\hline $\mathrm{Ba}$ & 23 & 47 & 50 & 19 & 19 & 44 & 36 & 0.7 & 31 & 56 & 44 & 62 & 54 & 388 \\
\hline $\mathrm{La}$ & 1.67 & 1.81 & 2.62 & 5.47 & 1.31 & 1.70 & 1.77 & 3.02 & 2.55 & 2.60 & 7.46 & 3.02 & 3.35 & 3.60 \\
\hline $\mathrm{Ce}$ & 3.94 & 3.86 & 5.52 & 12.64 & 3.37 & 3.27 & 3.90 & 6.98 & 5.25 & 4.87 & 15.77 & 6.46 & 7.11 & 8.10 \\
\hline Pr & 0.64 & 0.59 & 0.80 & 1.32 & 0.48 & 0.46 & 0.57 & 1.48 & 0.82 & 0.82 & 1.81 & 0.96 & 1.08 & 1.41 \\
\hline Nd & 3.05 & 2.84 & 3.65 & 5.98 & 2.32 & 2.20 & 2.62 & 7.15 & 3.90 & 3.99 & 7.85 & 4.64 & 5.08 & 5.90 \\
\hline $\mathrm{Sm}$ & 0.81 & 0.81 & 0.97 & 1.48 & 0.61 & 0.63 & 0.79 & 2.24 & 1.14 & 1.18 & 1.82 & 1.24 & 1.40 & 1.39 \\
\hline $\mathrm{Eu}$ & 0.28 & 0.27 & 0.34 & 0.43 & 0.24 & 0.22 & 0.26 & 0.76 & 0.38 & 0.40 & 0.56 & 0.39 & 0.37 & 0.46 \\
\hline Gd & 0.94 & 0.97 & 1.20 & 1.71 & 0.78 & 0.79 & 0.88 & 2.29 & 1.38 & 1.30 & 1.84 & 1.59 & 1.56 & 2.16 \\
\hline $\mathrm{Tb}$ & 0.16 & 0.16 & 0.21 & 0.30 & 0.14 & 0.14 & 0.15 & 0.38 & 0.24 & 0.25 & 0.37 & 0.24 & 0.30 & 0.26 \\
\hline Dy & 1.09 & 1.05 & 1.21 & 1.84 & 0.84 & 0.80 & 0.95 & 2.52 & 1.61 & 1.70 & 2.46 & 1.49 & 1.90 & 1.82 \\
\hline Ho & 0.24 & 0.23 & 0.27 & 0.44 & 0.17 & 0.18 & 0.20 & 0.53 & 0.29 & 0.37 & 0.57 & 0.32 & 0.39 & 0.38 \\
\hline $\mathrm{Er}$ & 0.70 & 0.69 & 0.77 & 1.38 & 0.56 & 0.49 & 0.64 & 1.35 & 0.98 & 1.02 & 1.90 & 1.03 & 1.15 & 1.21 \\
\hline $\mathrm{Tm}$ & 0.11 & 0.11 & 0.14 & 0.25 & 0.10 & 0.08 & 0.11 & 0.21 & 0.14 & 0.17 & 0.33 & 0.16 & 0.20 & 0.18 \\
\hline $\mathrm{Yb}$ & 0.72 & 0.80 & 0.92 & 1.40 & 0.70 & 0.54 & 0.70 & 1.30 & 0.99 & 1.07 & 2.14 & 1.04 & 1.22 & 1.17 \\
\hline $\mathrm{Lu}$ & 0.12 & 0.14 & 0.15 & 0.25 & 0.11 & 0.09 & 0.12 & 0.21 & 0.16 & 0.16 & 0.33 & 0.15 & 0.21 & 0.19 \\
\hline $\mathrm{Hf}$ & 0.96 & 0.90 & 1.15 & 1.00 & 1.02 & 0.86 & 1.16 & 1.37 & 1.29 & 1.23 & 1.62 & 1.67 & 2.19 & 2.10 \\
\hline $\mathrm{Ta}$ & 0.04 & 0.03 & 0.05 & 0.05 & 0.03 & 0.04 & 0.05 & 0.06 & 0.04 & 0.05 & 0.06 & 0.06 & 0.08 & 0.08 \\
\hline $\mathrm{Pb}$ & 1.57 & 1.50 & 4.66 & 2.00 & 2.37 & 1.73 & 1.78 & 2.29 & 1.79 & 2.30 & 2.30 & 2.24 & 2.80 & 3.19 \\
\hline Th & 0.27 & 0.27 & 0.31 & 0.27 & 0.34 & 0.32 & 0.34 & 0.37 & 0.46 & 0.35 & 0.58 & 0.55 & 0.72 & 0.67 \\
\hline$U$ & 0.14 & 0.18 & 0.26 & 0.14 & 0.13 & 0.23 & 0.18 & 0.11 & 0.19 & 0.27 & 0.40 & 0.27 & 0.44 & 0.37 \\
\hline
\end{tabular}

Chondrite normalized

\begin{tabular}{|c|c|c|c|c|c|c|c|c|c|c|c|c|c|c|}
\hline $\mathrm{La}$ & 5.39 & 5.84 & 8.45 & 17.65 & 4.23 & 5.48 & 5.71 & 9.74 & 8.23 & 8.39 & 24.06 & 9.74 & 10.81 & 11.61 \\
\hline $\mathrm{Ce}$ & 4.88 & 4.78 & 6.83 & 15.64 & 4.17 & 4.05 & 4.83 & 8.64 & 6.50 & 6.03 & 19.52 & 8.00 & 8.80 & 10.02 \\
\hline $\operatorname{Pr}$ & 5.25 & 4.84 & 6.56 & 10.82 & 3.93 & 3.77 & 4.67 & 12.13 & 6.72 & 6.72 & 14.84 & 7.87 & 8.85 & 11.56 \\
\hline $\mathrm{Nd}$ & 5.08 & 4.73 & 6.08 & 9.97 & 3.87 & 3.67 & 4.37 & 11.92 & 6.50 & 6.65 & 13.08 & 7.73 & 8.47 & 9.83 \\
\hline $\mathrm{Sm}$ & 4.15 & 4.15 & 4.97 & 7.59 & 3.13 & 3.23 & 4.05 & 11.49 & 5.85 & 6.05 & 9.33 & 6.36 & 7.18 & 7.13 \\
\hline $\mathrm{Eu}$ & 3.81 & 3.67 & 4.63 & 5.85 & 3.27 & 2.99 & 3.54 & 10.34 & 5.17 & 5.37 & 7.62 & 5.31 & 5.03 & 6.26 \\
\hline Gd & 3.63 & 3.75 & 4.63 & 6.60 & 3.01 & 3.05 & 3.40 & 8.84 & 5.33 & 5.02 & 7.10 & 6.14 & 6.02 & 8.34 \\
\hline $\mathrm{Tb}$ & 3.38 & 3.38 & 4.43 & 6.33 & 2.95 & 2.95 & 3.16 & 8.02 & 5.06 & 5.27 & 7.81 & 5.06 & 6.33 & 5.49 \\
\hline Dy & 3.39 & 3.26 & 3.76 & 5.71 & 2.61 & 2.48 & 2.95 & 7.83 & 5.00 & 5.28 & 7.64 & 4.63 & 5.90 & 5.65 \\
\hline Ho & 3.34 & 3.20 & 3.76 & 6.13 & 2.37 & 2.44 & 2.79 & 7.38 & 4.04 & 5.15 & 7.94 & 4.46 & 5.43 & 5.29 \\
\hline $\mathrm{Er}$ & 3.33 & 3.29 & 3.67 & 6.57 & 2.67 & 2.33 & 3.05 & 6.43 & 4.67 & 4.86 & 9.05 & 4.90 & 5.48 & 5.76 \\
\hline $\mathrm{Tm}$ & 3.40 & 3.40 & 4.32 & 7.72 & 3.09 & 2.47 & 3.40 & 6.48 & 4.32 & 5.25 & 10.19 & 4.94 & 6.17 & 5.56 \\
\hline $\mathrm{Yb}$ & 3.44 & 3.83 & 4.40 & 6.70 & 3.35 & 2.58 & 3.35 & 6.22 & 4.74 & 5.12 & 10.24 & 4.98 & 5.84 & 5.60 \\
\hline $\mathrm{Lu}$ & 3.57 & 4.35 & 4.66 & 7.76 & 3.42 & 2.70 & 3.73 & 6.52 & 4.97 & 4.97 & 10.25 & 4.66 & 6.52 & 5.90 \\
\hline
\end{tabular}

Note: Missing values not analyzed. Magma types: $\mathrm{LCB}=$ low-Ca boninite, $\mathrm{LCBrzA}=$ low-Ca bronzite andesite, ICB $=$ intermediate-Ca boninite, ICBrzA $=$ intermediate-Ca bronzite andesite, $\mathrm{A}=$ andesite, $\mathrm{D}=$ dacite, $\mathrm{R}=$ rhyolite, $\mathrm{HCB}=$ high-Ca boninite, $\mathrm{BA}=$ basaltic andesite, Th $\mathrm{A}=$ tholeiitic andesite, ThD = tholeiitic dacite.

"Exhibits extreme secondary REE enrichment. 
Table 1 (continued).

\begin{tabular}{|c|c|c|c|c|c|c|c|c|c|c|c|}
\hline $786 \mathrm{~B}$ & $786 \mathrm{~B}$ & $786 \mathrm{~B}$ & $786 \mathrm{~B}$ & $786 \mathrm{~A}$ & $786 \mathrm{~A}$ & $786 \mathrm{~A}$ & $786 \mathrm{~A}$ & $786 \mathrm{~A}$ & $782 \mathrm{~A}$ & $782 \mathrm{~A}$ & $782 \mathrm{~A}$ \\
\hline $63 R-2$ & $21 \mathrm{R}-2$ & $67 R-1$ & $40 \mathrm{R}-2$ & $5 R-2$ & $17 \mathrm{X}-\mathrm{CC}$ & $16 \mathrm{X}-\mathrm{CC}$ & $12 X-1$ & $6 X-5$ & $50 \times-1$ & $49 X-C C$ & $50 \times-1$ \\
\hline $72-74$ & $72-76$ & $56-59$ & $54-57$ & $70-72$ & $4-6$ & $25-28$ & $140-142$ & $24-27$ & $37-42$ & $31-34$ & $32-35$ \\
\hline IV-29 & IV-9 & IV-32 & IV-23 & IV -2 & IV-0 & IV-0 & II & II & II & II & II \\
\hline $\mathrm{R}$ & ICB & ICB & HCB & НCB & ICB & ICB & BA & BA & ThA & ThA & $\mathrm{ThD}$ \\
\hline 74.29 & 50.62 & 53.00 & 47.23 & 50.23 & 48.68 & 51.00 & 51.43 & 52.27 & 56.10 & 56.00 & 66.97 \\
\hline 0.24 & 0.23 & 0.25 & 0.31 & 0.37 & 0.20 & 0.24 & 0.40 & 0.82 & 0.78 & 0.75 & 0.45 \\
\hline 12.41 & 11.80 & 12.46 & 12.06 & 14.40 & 11.43 & 14.62 & 17.27 & 16.12 & 14.96 & 14.60 & 14.25 \\
\hline 1.92 & 8.14 & 7.54 & 8.05 & 8.55 & 9.23 & 7.81 & 8.34 & 12.23 & 10.92 & 10.18 & 4.05 \\
\hline 0.01 & 0.14 & 0.14 & 0.14 & 0.11 & 0.12 & 0.13 & 0.09 & 0.20 & 0.15 & 0.14 & 0.10 \\
\hline 0.00 & 13.07 & 13.08 & 11.40 & 7.67 & 14.38 & 11.53 & 5.34 & 4.10 & 3.59 & 2.85 & 0.68 \\
\hline 0.45 & 5.90 & 6.70 & 11.90 & 10.89 & 6.58 & 8.06 & 8.20 & 9.65 & 7.85 & 6.87 & 3.37 \\
\hline 4.85 & 2.38 & 2.76 & 2.12 & 2.56 & 2.71 & 3.03 & 2.82 & 1.59 & 3.35 & 3.88 & 3.95 \\
\hline 4.98 & 0.39 & 0.21 & 0.26 & 1.25 & 0.70 & 0.32 & 1.38 & 0.34 & 0.51 & 0.53 & 1.08 \\
\hline 0.08 & 0.07 & 0.04 & 0.04 & 0.10 & 0.01 & 0.01 & 0.02 & 0.01 & 0.07 & 0.05 & 0.07 \\
\hline 0.27 & 5.75 & 2.56 & 5.46 & 3.40 & 6.16 & 2.41 & 2.92 & 0.84 & 1.56 & 2.18 & 3.49 \\
\hline 99.50 & 98.49 & 98.74 & 98.97 & 99.53 & 100.20 & 99.16 & 98.21 & 98.17 & 99.84 & 98.03 & 98.46 \\
\hline 8.2 & 26.1 & 33.7 & 27.1 & 30.3 & 24.8 & 29.3 & 31.1 & 41.2 & 13.9 & & 12.7 \\
\hline 1 & 889 & 786 & 762 & 404 & 608 & 557 & 320 & 23 & 13 & & \\
\hline 22 & 185 & 202 & 193 & 237 & 194 & 226 & 330 & 428 & 286 & 459 & 32 \\
\hline 1 & 223 & 296 & 374 & 170 & 25 & 190 & 85 & 18 & 14 & 8 & 3 \\
\hline 1.0 & 39.9 & 38.5 & 44.6 & 40.7 & 41.4 & 40.2 & 26.2 & & 21.0 & & 4.0 \\
\hline 63 & 40 & 56 & 27 & 63 & 160 & 37 & 40 & 166 & 60 & 115 & 11 \\
\hline 41 & 54 & 58 & 57 & 63 & 73 & 68 & 62 & 113 & 75 & 90 & 104 \\
\hline 44.0 & 6.8 & 3.1 & 7.6 & 5.8 & 9.5 & 3.1 & 14.0 & 6.1 & 8.3 & 6.1 & 17.6 \\
\hline 44 & 145 & 136 & 139 & 147 & 93 & 143 & 171 & 180 & 188.4 & 175 & 160 \\
\hline 11.7 & 7.6 & 6.5 & 8.2 & 10.6 & 6.0 & 6.2 & 6.1 & 22.0 & 16.1 & 16.5 & 19.8 \\
\hline 85 & 28 & 27 & 26 & 33 & 25 & 28 & 46 & 40 & 61 & 57 & 100 \\
\hline 1.00 & 0.54 & 0.44 & 0.53 & 0.39 & 0.42 & 0.39 & 0.66 & 0.25 & 0.51 & 0.50 & 0.78 \\
\hline 578 & 18 & 7.6 & 15 & 17 & 7.8 & 27 & 18 & 77 & 21 & 25 & 35 \\
\hline 4.83 & 1.47 & 1.15 & 1.50 & 2.22 & 0.52 & 1.12 & 0.72 & 1.24 & 2.01 & 2.97 & 4.47 \\
\hline 9.12 & 2.88 & 2.57 & 3.05 & 4.13 & 1.43 & 2.60 & 3.88 & 4.23 & 5.83 & 6.43 & 10.7 \\
\hline 1.30 & 0.46 & 0.37 & 0.50 & 0.78 & 0.21 & 0.44 & 0.32 & 0.80 & 0.97 & 1.02 & 1.92 \\
\hline 6.20 & 2.19 & 1.97 & 2.61 & 3.80 & 1.11 & 2.17 & 1.95 & 4.54 & 5.30 & 5.25 & 9.66 \\
\hline 1.87 & 0.63 & 0.61 & 0.80 & 1.07 & 0.38 & 0.61 & 0.56 & 1.63 & 1.72 & 1.56 & 2.56 \\
\hline 0.37 & 0.23 & 0.22 & 0.31 & 0.40 & 0.14 & 0.23 & 0.29 & 0.63 & 0.64 & 0.55 & 0.74 \\
\hline 1.77 & 0.89 & 0.81 & 1.06 & 1.41 & 0.51 & 0.77 & 0.81 & 2.31 & 2.21 & 2.03 & 3.03 \\
\hline 0.31 & 0.16 & 0.15 & 0.20 & 0.26 & 0.09 & 0.14 & 0.14 & 0.41 & 0.34 & 0.35 & 0.54 \\
\hline 1.93 & 1.09 & 1.00 & 1.30 & 1.70 & 0.69 & 1.03 & 0.99 & 2.94 & 2.50 & 2.55 & 3.44 \\
\hline 0.48 & 0.27 & 0.21 & 0.30 & 0.37 & 0.15 & 0.21 & 0.21 & 0.63 & 0.47 & 0.53 & 0.68 \\
\hline 1.27 & 0.74 & 0.72 & 0.84 & 1.10 & 0.41 & 0.64 & 0.58 & 1.90 & 1.53 & 1.64 & 2.07 \\
\hline 0.20 & 0.12 & 0.12 & 0.14 & 0.17 & 0.08 & 0.11 & 0.1 & 0.28 & 0.24 & 0.29 & 0.31 \\
\hline 1.24 & 0.76 & 0.75 & 0.87 & 1.14 & 0.56 & 0.77 & 0.63 & 2.03 & 1.59 & 1.81 & 2.08 \\
\hline 0.21 & 0.11 & 0.11 & 0.13 & 0.17 & 0.08 & 0.12 & 0.09 & 0.38 & 0.27 & 0.30 & 0.30 \\
\hline 2.41 & 0.78 & 0.70 & 0.70 & 0.89 & 0.72 & 0.83 & 1.24 & 1.14 & 1.68 & 1.66 & 2.80 \\
\hline 0.07 & 0.03 & 0.03 & 0.02 & 0.02 & 0.02 & 0.02 & 0.04 & 0.02 & 0.05 & 0.04 & 0.07 \\
\hline 2.84 & 0.79 & 0.72 & 0.84 & 0.70 & 0.68 & 1.41 & 4.80 & 3.14 & 1.74 & 1.48 & 2.76 \\
\hline 0.65 & 0.19 & 0.17 & 0.18 & 0.18 & 0.12 & 0.17 & 0.25 & 0.06 & 0.20 & 0.17 & 0.40 \\
\hline 0.47 & 0.16 & 0.12 & 0.14 & 0.20 & 0.29 & 0.12 & 0.22 & 0.07 & 0.20 & 0.11 & 0.21 \\
\hline 15.58 & 4.74 & 3.71 & 4.84 & 7.16 & 1.68 & 3.61 & 2.32 & 4.00 & 6.48 & 9.58 & 14.42 \\
\hline 11.29 & 3.56 & 3.18 & 3.77 & 5.11 & 1.77 & 3.22 & 4.80 & 5.24 & 7.22 & 7.96 & 13.24 \\
\hline 10.66 & 3.77 & 3.03 & 4.10 & 6.39 & 1.72 & 3.61 & 2.62 & 6.56 & 7.95 & 8.36 & 15.74 \\
\hline 10.33 & 3.65 & 3.28 & 4.35 & 6.33 & 1.85 & 3.62 & 3.25 & 7.57 & 8.83 & 8.75 & 16.10 \\
\hline 9.59 & 3.23 & 3.13 & 4.10 & 5.49 & 1.95 & 3.13 & 2.87 & 8.36 & 8.82 & 8.00 & 13.13 \\
\hline 5.03 & 3.13 & 2.99 & 4.22 & 5.44 & 1.90 & 3.13 & 3.95 & 8.57 & 8.71 & 7.48 & 10.07 \\
\hline 6.83 & 3.44 & 3.13 & 4.09 & 5.44 & 1.97 & 2.97 & 3.13 & 8.92 & 8.53 & 7.84 & 11.70 \\
\hline 6.54 & 3.38 & 3.16 & 4.22 & 5.49 & 1.90 & 2.95 & 2.95 & 8.65 & 7.17 & 7.38 & 11.39 \\
\hline 5.99 & 3.39 & 3.11 & 4.04 & 5.28 & 2.14 & 3.20 & 3.07 & 9.13 & 7.76 & 7.92 & 10.68 \\
\hline 6.69 & 3.76 & 2.92 & 4.18 & 5.15 & 2.09 & 2.92 & 2.92 & 8.77 & 6.55 & 7.38 & 9.47 \\
\hline 6.05 & 3.52 & 3.43 & 4.00 & 5.24 & 1.95 & 3.05 & 2.76 & 9.05 & 7.29 & 7.81 & 9.86 \\
\hline 6.17 & 3.70 & 3.70 & 4.32 & 5.25 & 2.47 & 3.40 & 3.09 & 8.64 & 7.41 & 8.95 & 9.57 \\
\hline 5.93 & 3.64 & 3.59 & 4.16 & 5.45 & 2.68 & 3.68 & 3.01 & 9.71 & 7.61 & 8.66 & 9.95 \\
\hline 6.52 & 3.42 & 3.42 & 4.04 & 5.28 & 2.48 & 3.73 & 2.80 & 11.80 & 8.39 & 9.32 & 9.32 \\
\hline
\end{tabular}




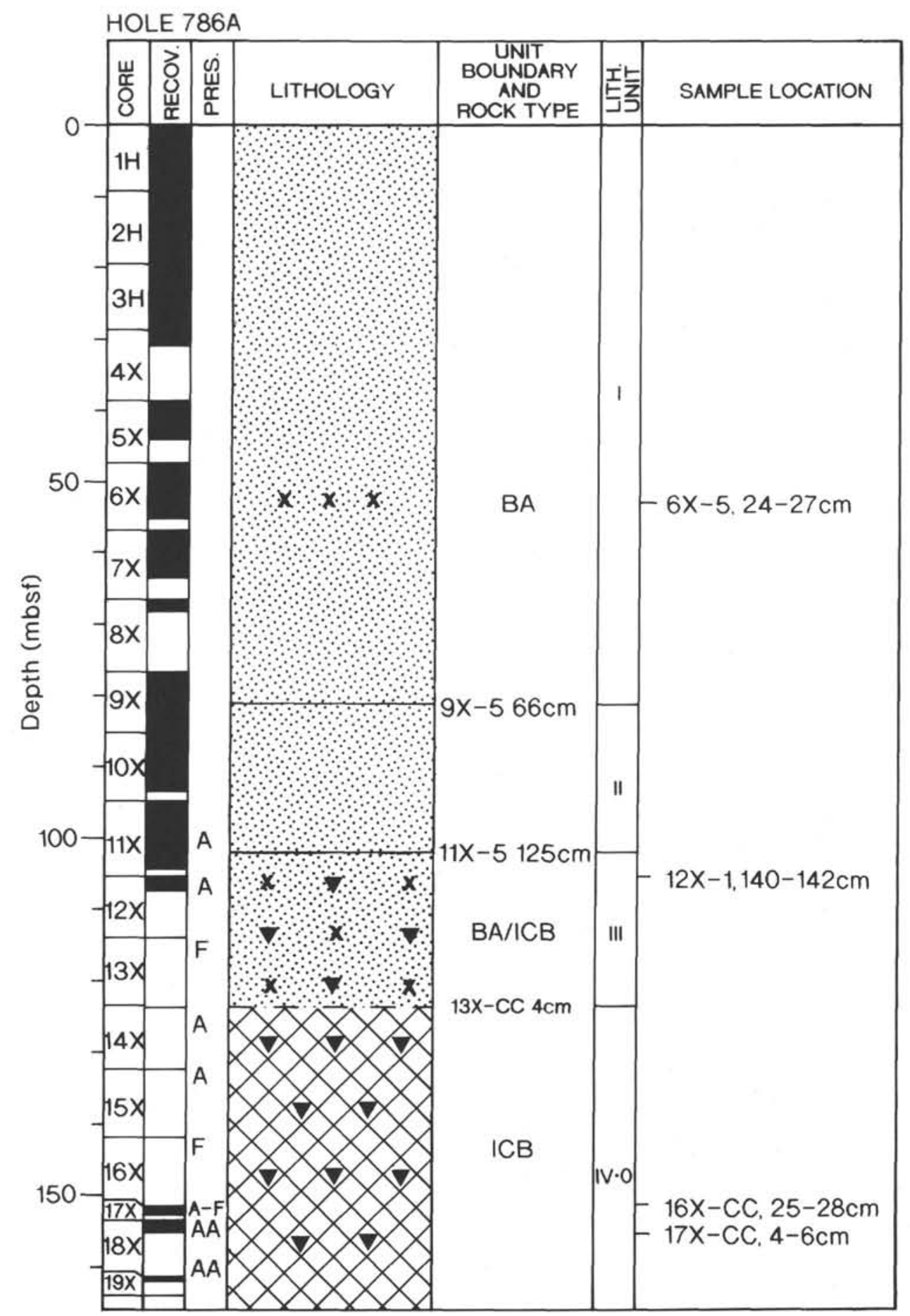

Figure 2. Stratigraphic section for Site 786 (Arculus et al., this volume) showing locations of samples chosen for isotope analysis.

recent samples, we decided to use present-day values for regional comparisons. However, the mobility of $\mathrm{U}$ and $\mathrm{Pb}$ (see next section) has caused many of the present-day $\mathrm{Pb}$ isotope ratios to have evolved from their initial ratios along alteration vectors. The high present-day ${ }^{238} \mathrm{U} /{ }^{235} \mathrm{U}$ ratio means that ${ }^{206} \mathrm{~Pb}$ is more affected by alteration than ${ }^{207} \mathrm{~Pb}$. Although alteration-induced variations in ${ }^{206} \mathrm{~Pb}$ are small in absolute terms, they are significant compared with analytical errors and can distort intra-sample variations. The lead isotope values have therefore been alteration-corrected in three stages: (1) by extrapola- tion back to the assumed age of alteration using present-day $\mathrm{U} / \mathrm{Pb}$ and $\mathrm{Th} / \mathrm{Pb}$ ratios; (2) further extrapolation back to the age of eruption along inferred primary ratios; and (3) projection from the initial ratios to present-day values using the calculated ratios of their mantle sources. Ages of metamorphism and eruption or intrusion are inferred in part from $\mathrm{K}-\mathrm{Ar}$ ages discussed in the previous section and the alteration corrections are discussed in the next section. The corrected values are given in Table 3 with the subscript "r." Although this method makes a number of assumptions, the result is a slightly more 
HOLE 786B

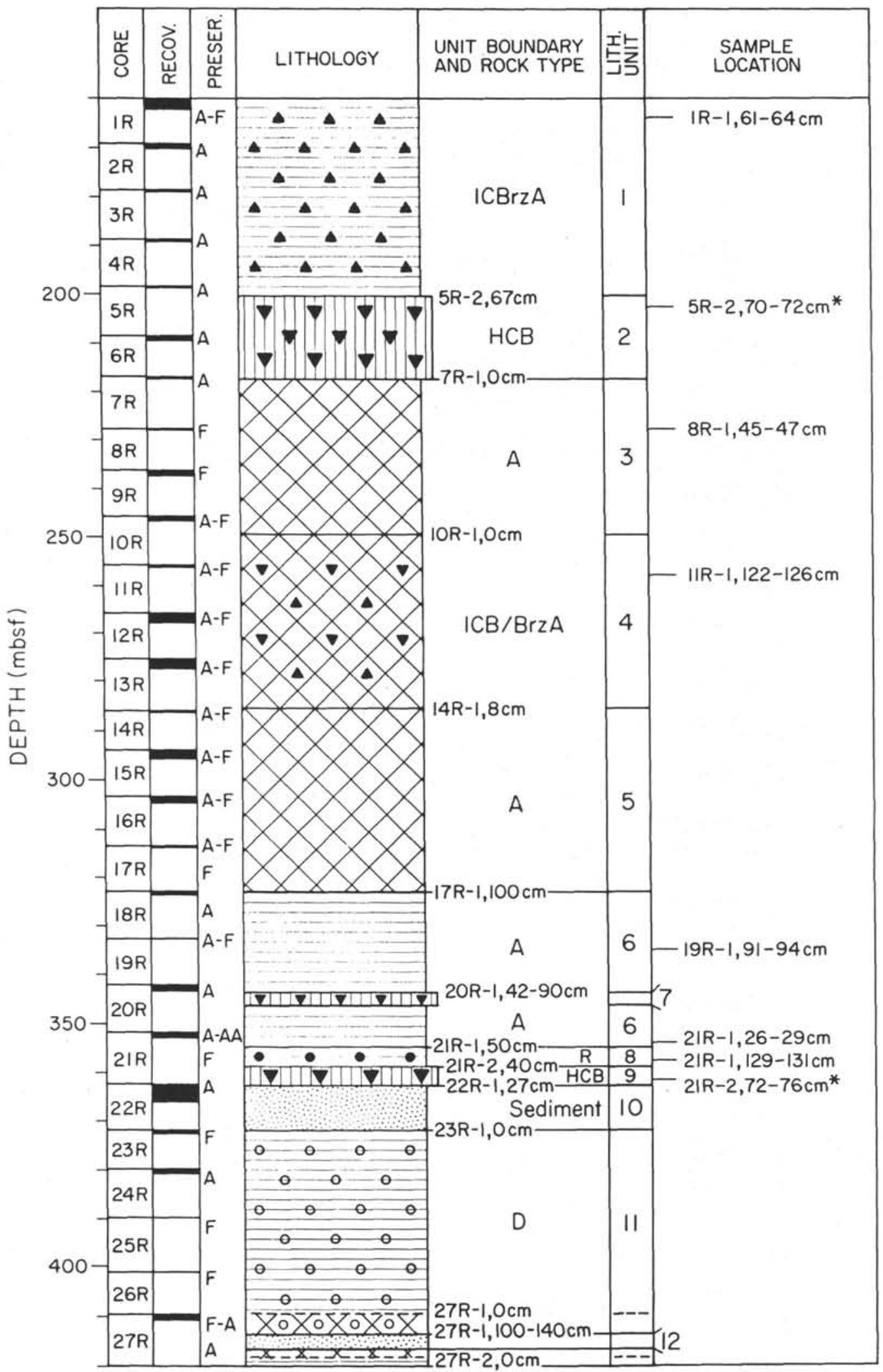

Figure 2 (continued). 


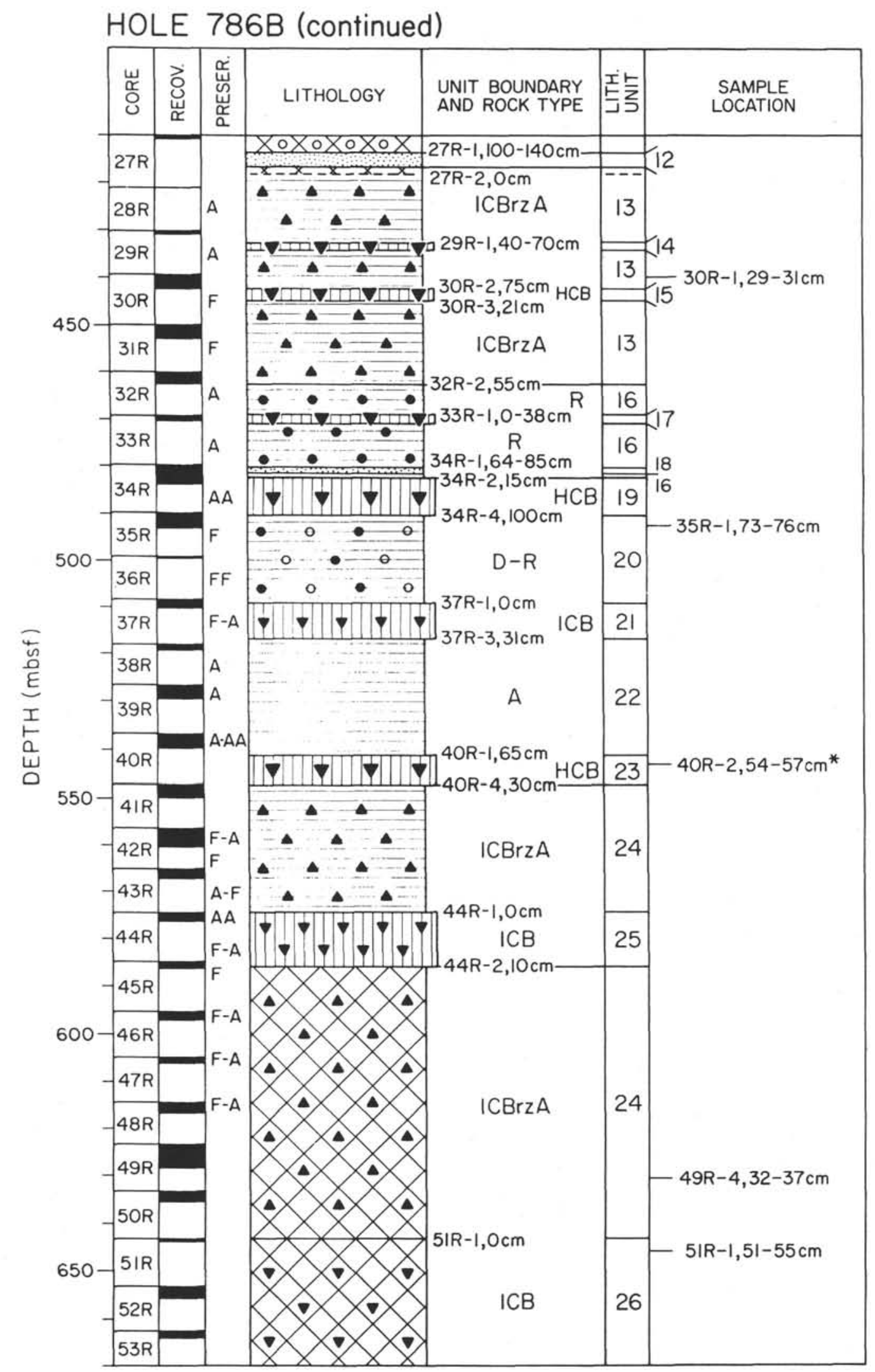

Figure 2 (continued). 


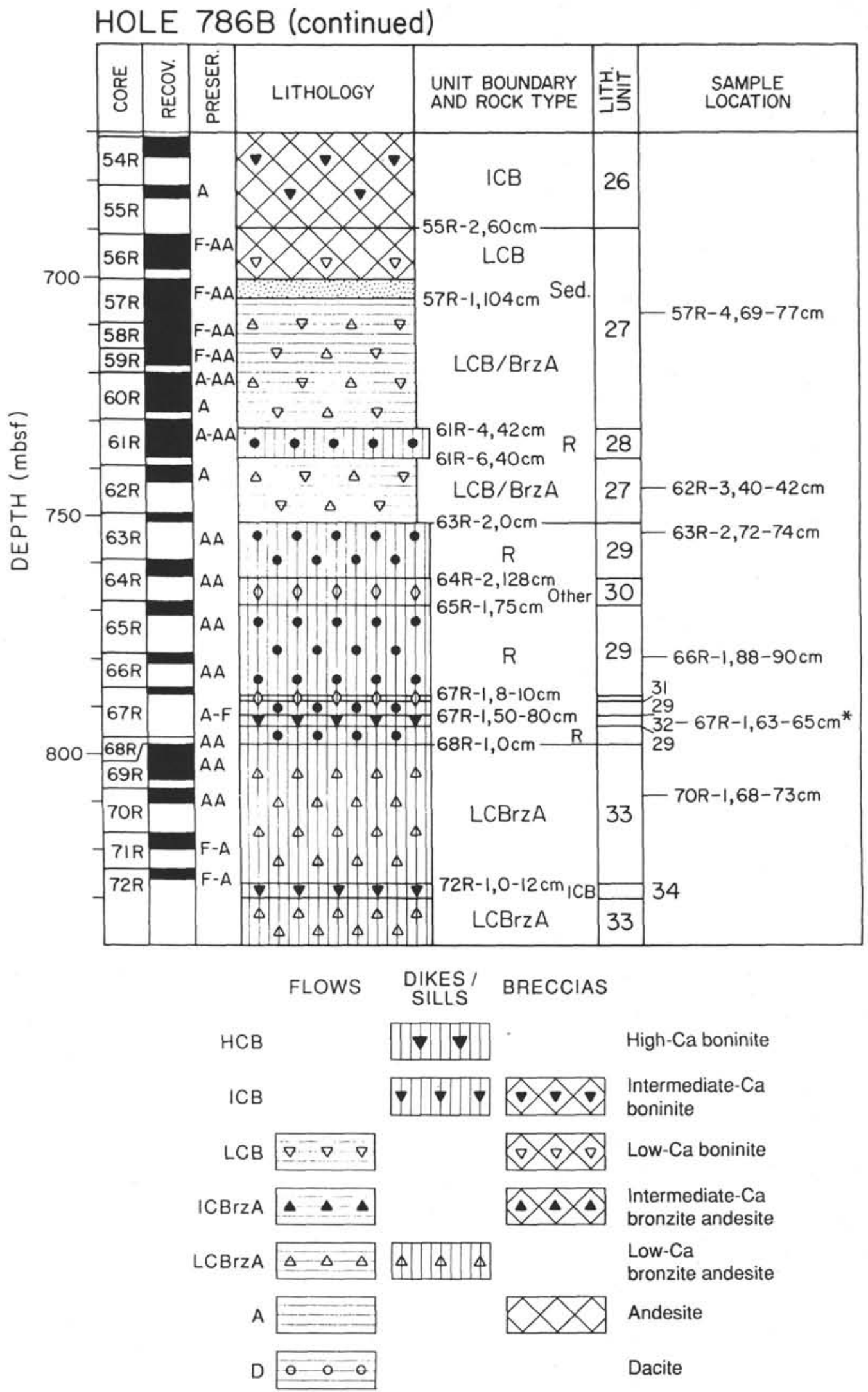

Figure 2 (continued). 
Table 2. Isotopic analyses and initial isotopic ratios of samples from Leg 125. For analytical details, see the text.

\begin{tabular}{|c|c|c|c|c|c|c|c|c|}
\hline $\begin{array}{l}\text { Hole, Core, } \\
\text { Interval }(\mathrm{cm})\end{array}$ & $\begin{array}{l}\text { Rock } \\
\text { type }\end{array}$ & $\begin{array}{l}\text { Age } \\
\text { (Ma) }\end{array}$ & ${ }^{87} \mathrm{Sr} /{ }^{86} \mathrm{Sr}$ & $\left({ }^{87} \mathrm{Sr} /{ }^{86} \mathrm{Sr}\right)_{0}$ & $\varepsilon \mathrm{Sr}$ & ${ }^{143} \mathrm{Nd} /{ }^{144} \mathrm{Nd}$ & $\left({ }^{143} \mathrm{Nd} / /^{144} \mathrm{Nd}\right)_{0}$ & $\varepsilon N d$ \\
\hline $786 \mathrm{~B}-57 \mathrm{R}-4,69-77$ & LCB & 41 & $0.703836 \pm 9$ & 0.703836 & -11.56 & $0.512948 \pm 4$ & 0.512904 & 6.23 \\
\hline $786 \mathrm{~B}-62 \mathrm{R}-3,40-42$ & LCB & 41 & $0.703740 \pm 12$ & 0.703740 & -12.92 & $0.512973 \pm 6$ & 0.512926 & 6.65 \\
\hline 786B-70R-1, 68-73 & LCBrzA & 41 & $0.703721 \pm 9$ & 0.703721 & -13.19 & $0.512976 \pm 4$ & 0.512932 & 6.77 \\
\hline 786B-51R-1, 51-55 & ICB & 41 & $0.703598 \pm 9$ & 0.703598 & -14.94 & $0.512982 \pm 4$ & 0.512942 & 6.95 \\
\hline $786 \mathrm{~B}-11 \mathrm{R}-1,122-126$ & ICB & 41 & $0.703588 \pm 9$ & 0.703530 & -15.90 & $0.512987 \pm 5$ & 0.512945 & 7.02 \\
\hline 786B-30R-1, 29-31 & ICBrzA & 41 & $0.703584 \pm 10$ & 0.703584 & -15.15 & $0.512989 \pm 6$ & 0.512942 & 6.96 \\
\hline 786B-1R-1, 61-64 & ICBrzA & 41 & $0.703542 \pm 7$ & 0.703542 & -15.75 & $0.512988 \pm 14$ & 0.512940 & 6.91 \\
\hline $786 \mathrm{~B}-8 \mathrm{R}-1,45-47$ & A & 41 & $0.703514 \pm 11$ & 0.703514 & -16.13 & $0.512987 \pm 4$ & 0.512937 & 6.86 \\
\hline 786B-19R-1,91-94 & A & 41 & $0.703577 \pm 11$ & 0.703517 & -16.09 & $0.512983 \pm 7$ & 0.512936 & 6.85 \\
\hline $786 \mathrm{~B}-49 \mathrm{R}-4,32-37$ & A & 41 & $0.703692 \pm 8$ & 0.703595 & -14.98 & $0.512980 \pm 5$ & 0.512932 & 6.76 \\
\hline $786 \mathrm{~B}-21 \mathrm{R}-1,26-29$ & A & 41 & $0.703533 \pm 12$ & 0.703533 & -15.86 & $0.512978 \pm 7$ & 0.512941 & 6.94 \\
\hline 786B-35R-1, 73-76 & D & 41 & $0.703547 \pm 12$ & 0.703547 & -15.66 & & & \\
\hline $786 \mathrm{~B}-21 \mathrm{R}-1,129-131$ & $\mathrm{R}$ & 41 & $0.704698 \pm 15$ & 0.704318 & -4.72 & $0.512988 \pm 5$ & 0.512943 & 6.98 \\
\hline $786 \mathrm{~B}-66 \mathrm{R}-1,88-90$ & $\mathrm{R}$ & 41 & $0.704673 \pm 12$ & 0.704203 & -6.35 & $0.512996 \pm 6$ & 0.512957 & 7.26 \\
\hline $786 \mathrm{~B}-63 \mathrm{R}-2,72-74$ & $\mathbf{R}$ & 41 & $0.706079 \pm 10$ & 0.704390 & -3.70 & & & \\
\hline 786B-21R-2, 72-76 & ICB & 35 & $0.703404 \pm 10$ & 0.703404 & -17.71 & $0.513020 \pm 5$ & 0.512980 & 7.55 \\
\hline 786B-67R-1, 63-65 & ICB & 35 & $0.703422 \pm 14$ & 0.703389 & -18.01 & $0.513024 \pm 6$ & 0.512981 & 7.58 \\
\hline $786 \mathrm{~B}-40 \mathrm{R}-2,54-57$ & $\mathrm{HCB}$ & 35 & $0.703331 \pm 12$ & 0.703331 & -18.75 & $0.513042 \pm 3$ & 0.513014 & 7.79 \\
\hline $786 \mathrm{~B}-5 \mathrm{R}-2,70-72$ & НСВ & 17 & $0.703301 \pm 9$ & 0.703301 & -19.25 & $0.513034 \pm 5$ & 0.513015 & 7.85 \\
\hline 786B-17X-CC, 4-6 & ICB & 35 & & & & & & \\
\hline 786B-16X-CC, $25-28$ & ICB & 35 & $0.703324 \pm 12$ & 0.703324 & -18.93 & $0.513037 \pm 4$ & 0.512998 & 7.91 \\
\hline $786 \mathrm{~A}-12 \mathrm{X}-1,140-142$ & BA & 17 & $0.703263 \pm 11$ & 0.703263 & -19.80 & $0.513040 \pm 6$ & 0.513000 & 7.94 \\
\hline $786 \mathrm{~B}-6 \mathrm{X}-5,24-27$ & BA & 10 & $0.703556 \pm 11$ & 0.703556 & -16.13 & $0.513114 \pm 4$ & 0.513100 & 9.26 \\
\hline $786 \mathrm{~A}-50 \mathrm{X}-1,37-42$ & ThA & 35 & & & & & & \\
\hline $782 \mathrm{~A}-49 \mathrm{X}-\mathrm{CC}, 31-34$ & ThA & 35 & $0.703471 \pm 11$ & 0.703471 & -16.84 & $0.513073 \pm 5$ & 0.513032 & 8.56 \\
\hline $782 \mathrm{~A}-45 \mathrm{X}-1,32-35$ & $\mathrm{ThD}$ & 35 & $0.703613 \pm 13$ & 0.703613 & -14.83 & $0.513056 \pm 4$ & 0.513019 & 8.31 \\
\hline
\end{tabular}

Note that Core 57R-4 is interpreted as having been contaminated by pelagic sediment on eruption and that the rhyolite Sr-isotopes are alteration-affected. For strongly leached samples, the initial $\mathrm{Sr}$ ratios are reported as the same as measured ratios. Calculations of initial ratios and epsilon values are based on trace element data in Table 1. The key to the rock names is given in Table 1.

coherent data set than that provided by the measured values. For example, ${ }^{206} \mathrm{~Pb} /{ }^{204} \mathrm{~Pb}$ values in samples from Cores $16 \mathrm{X}-\mathrm{CC}$ and $17 \mathrm{X}$-CC converge when alteration-induced $\mathrm{U}$-enrichment in the latter sample is taken into account. The corrected lead isotope data in Table 3 have also been quoted as delta values, relative to the Northern Hemisphere Reference Line of Hart (1984).

\section{ALTERATION EFFECTS}

Taylor et al. (in press) and Murton et al. (this volume) have demonstrated that a number of elements that are usually considered to be immobile may be mobilized during alteration of boninitic glass. Given the extent of alteration at Sites 782 and 786 , it is necessary, before considering primary isotopic variations, to take into account the effects of alteration on their isotope ratios and the associated elements. The plots in Figure 4, of $\mathrm{Sr}, \mathrm{Nd}$, and $\mathrm{Th}$ against $\mathrm{Zr}$ and $\mathrm{Pb}$ and $\mathrm{U}$ against $\mathrm{Th}$, have been chosen to demonstrate how alteration may have affected the elements of interest. They are drawn from the full trace element data set of Murton et al. (this volume), not simply the data in Table $1 . \mathrm{Zr}$ is used as the horizontal axis because it has been shown by the authors quoted above to have been one of the least mobile elements, having experienced only dilutions and concentrations caused by the transport of other elements into and out of the system. It thus gives an alteration-independent index of geochemical variation.

Figure 4A shows the behavior of $\mathrm{Sr}$. The intermediate-Ca boninites and bronzite andesites from Site 786 plot along a trend of increasing $\mathrm{Sr}$ with increasing $\mathrm{Zr}$, consistent with fractional crystallization and cumulation of mafic phases. This trend continues into the andesites, dacites, and rhyolites where $\mathrm{Sr}$ decreases in concentration as plagioclase becomes a crystallizing phase. The andesites and dacites from Site 782 form a similar trend, but displaced to lower $\mathrm{Sr}$ values for a given $\mathrm{Zr}$ content. The more altered low-Ca boninites and bronzite andesites form a trend which lies subparallel to that of the intermediate-Ca series but also displaced to lower $\mathrm{Sr}$ values. The fact that the main axis of dispersion for this group is in the direction of the mafic phase crystallization vector suggests that the low $\mathrm{Sr}$ is a primary, rather than alteration-induced, feature. The late dikes from Hole 786B form a cluster displaced to higher $\mathrm{Sr}$ for a given $\mathrm{Zr}$ content.

Although the scatter exceeds analytical error, many of the rocks are highly porphyritic (some plagioclase-phyric), which will enhance primary scatter. Thus, although $\mathrm{Sr}$ is theoretically a highly mobile element, its mobility has only masked primary variations in a very few of the analyzed samples. This conclusion concurs with that of Taylor et al. (in press), working on boninitic samples cored during Leg 126. They argued that, because $\mathrm{Sr}$ is mostly located within plagioclase, it may be less mobile than many of the normally more immobile incompatible elements that are located within the much more reactive boninitic glass.

Of the $\mathrm{Sr}$ isotope data in Table 2, all analyses of basic and intermediate samples were made on leached samples and show no correlation with alteration indices such as LOI (loss on ignition). However, the three unleached rhyolite samples all have significantly higher initial ratios. All three are strongly altered, exhibiting significant enrichment in $\mathrm{Rb}$. Moreover, their radiogenic $\mathrm{Sr}$ isotope ratios are not matched by the variations in other immobile element or isotope ratios that would be expected if these rocks originated by a different petrogenetic process. We therefore infer that these have undergone extensive interaction with seawater-derived fluids, and the data from these rocks are not plotted on the isotope diagrams that follow. The $\mathrm{Sr}$ isotope ratio of the sample from Core 57R-4 is also considered to be higher than the primary value, even though this sample has been leached. In this case the higher $\mathrm{Sr}$ isotope ratio is matched by a lower $\mathrm{Nd}$ isotope ratio and higher ratios of $\mathrm{Pb}$ isotopes (particularly ${ }^{207} \mathrm{~Pb} /{ }^{204} \mathrm{~Pb}$ ) compared with the otherwise similar low-Ca boninite from Core 62R-3. These characteristics indicate that the sample contains a pelagic sediment component. Because this component was not found in any of the surrounding rocks analyzed, we 
Table 2 (continued).

\begin{tabular}{cccccc}
\hline${ }^{206} \mathrm{~Pb} /{ }^{204} \mathrm{~Pb}$ & ${ }^{207} \mathrm{~Pb} /{ }^{204} \mathrm{~Pb}$ & ${ }^{208} \mathrm{~Pb}{ }^{204} \mathrm{~Pb}$ & $\left({ }^{206} \mathrm{~Pb} /{ }^{204} \mathrm{~Pb}\right)_{0}$ & $\left({ }^{207} \mathrm{~Pb} /{ }^{204} \mathrm{~Pb}\right)_{0}$ & $\left({ }^{208} \mathrm{~Pb} /{ }^{204} \mathrm{~Pb}\right)_{0}$ \\
\hline 18.755 & 15.566 & 38.737 & 18.719 & 15.564 & 38.714 \\
18.904 & 15.535 & 38.459 & 18.855 & 15.533 & 38.435 \\
18.901 & 15.528 & 38.445 & 18.878 & 15.527 & 38.436 \\
18.862 & 15.516 & 38.399 & 18.834 & 15.515 & 38.381 \\
18.835 & 15.524 & 38.397 & 18.813 & 15.523 & 38.378 \\
18.900 & 15.519 & 38.400 & 18.846 & 15.516 & 38.375 \\
18.816 & 15.515 & 38.361 & 18.775 & 15.513 & 38.335 \\
18.808 & 15.523 & 38.403 & 18.788 & 15.522 & 38.381 \\
& & & & & \\
18.873 & 15.520 & 38.409 & 18.825 & 15.518 & 38.389 \\
18.862 & 15.526 & 38.434 & 18.791 & 15.523 & 38.400 \\
& & & & & \\
18.848 & 15.505 & 38.365 & 18.784 & 15.502 & 38.311 \\
& & & & & \\
18.826 & 15.513 & 38.308 & 18.744 & 15.509 & 38.276 \\
18.804 & 15.529 & 38.381 & 18.746 & 15.526 & 38.368 \\
18.782 & 15.525 & 38.348 & 18.724 & 15.522 & 38.324 \\
18.744 & 15.509 & 38.281 & 18.696 & 15.507 & 38.267 \\
18.876 & 15.514 & 38.295 & 18.789 & 15.510 & 38.278 \\
18.826 & 15.517 & 38.318 & 18.797 & 15.515 & 38.301 \\
18.584 & 15.540 & 38.412 & 18.568 & 15.539 & 38.406 \\
18.381 & 15.485 & 38.170 & 18.379 & 15.485 & 38.169 \\
18.620 & 15.462 & 38.103 & 18.580 & 15.460 & 38.090 \\
18.667 & 15.497 & 38.266 & 18.641 & 15.496 & 38.253 \\
18.629 & 15.481 & 38.174 & 18.603 & 15.480 & 38.158 \\
\hline & & & & & \\
\hline
\end{tabular}

Table 3. Recalculated (alteration corrected) lead isotope ratios (subscript $r$ ) and delta values for Leg 125 samples. ${ }^{a}$

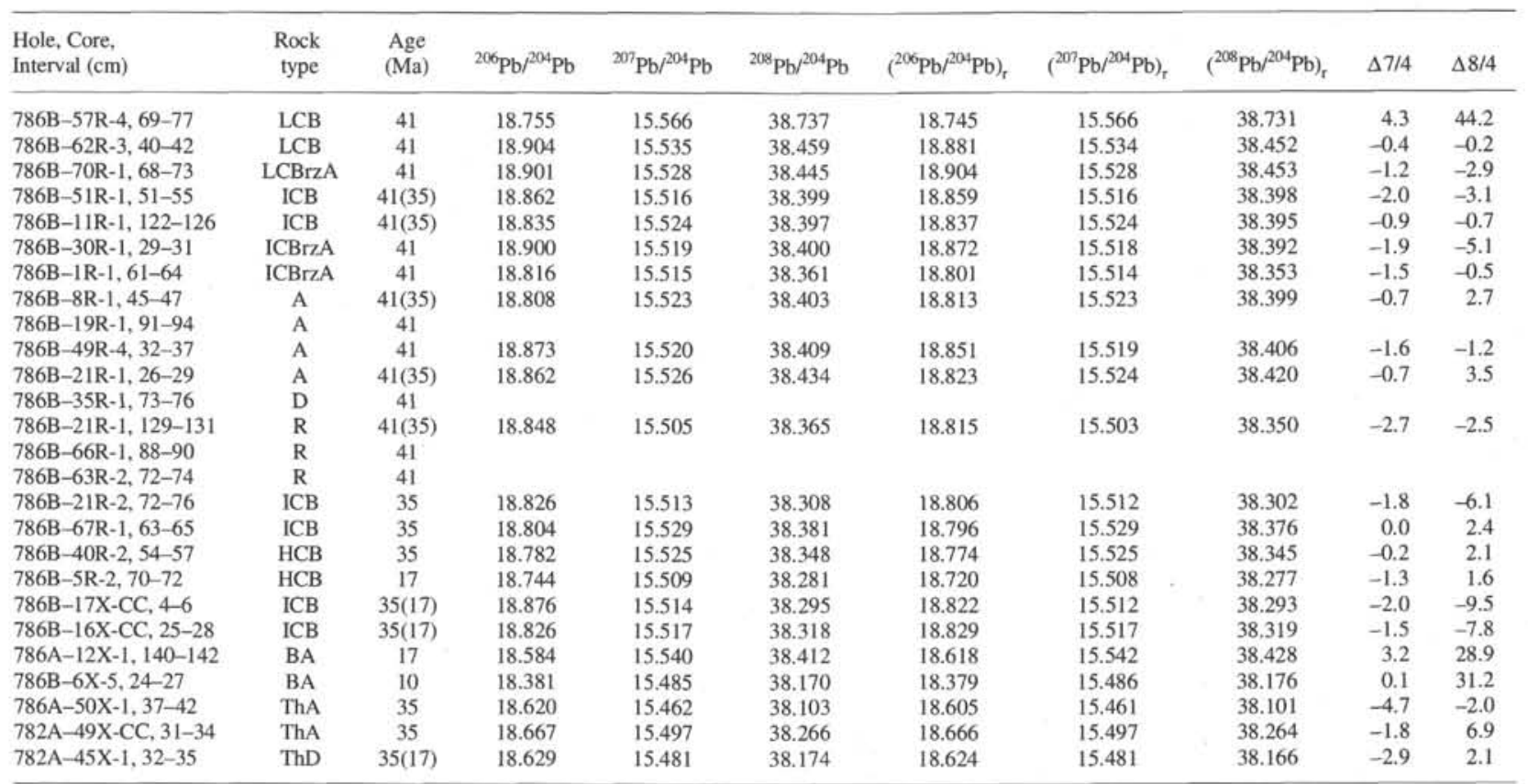

"The assumed metamorphic age is given in parentheses if it differs from the magmatic age. The key to the rock names is given in Table 1.

suspect that the "brown clay" identified in vesicles and microfractures is pelagic sediment incorporated during eruption on the seafloor. This sample is therefore omitted from further discussion.

Figure $4 \mathrm{~B}$ shows the behavior of $\mathrm{Nd}$ relative to $\mathrm{Zr}$. This diagram shows a main axis of dispersion for all groups toward increasing $\mathrm{Nd}$ and $\mathrm{Zr}$ contents, consistent with major phase crystallization. However, some samples are displaced to high Nd contents beyond the limits of experimental error. This is most apparent in the chondritenormalized rare earth element (REE) data in Table 1. Samples from Cores 51R-1, 8R-1, and 21R-1 (26-30 cm) exhibit strong LREE enrichment compared with other samples from their magmatic groups. This enrichment is matched by enrichment in $\mathrm{P}$ but not by the variations in $\mathrm{Th}, \mathrm{Zr}$, or $\mathrm{Nb}$ that might be expected if it were a primary feature. REE mobility was also recognized in Leg 126 cores by Taylor et al. (in press) and attributed to alteration of the boninitic glass. Some of the late dikes form a trend parallel to the principal axis of dispersion but displaced to higher $\mathrm{Nd}$ for a given $\mathrm{Zr}$ content. This may be a primary feature. By contrast, the sample from Core $12 \mathrm{X}-1$ in Hole 786A has low REE contents and a positive $\mathrm{Ce}$ anomaly, indicative of loss of REE by leaching in an oxidizing environment.

Despite this evidence for extensive REE mobility, however, the $\varepsilon N d$ values of the LREE-enriched samples from the LCB and ADR 

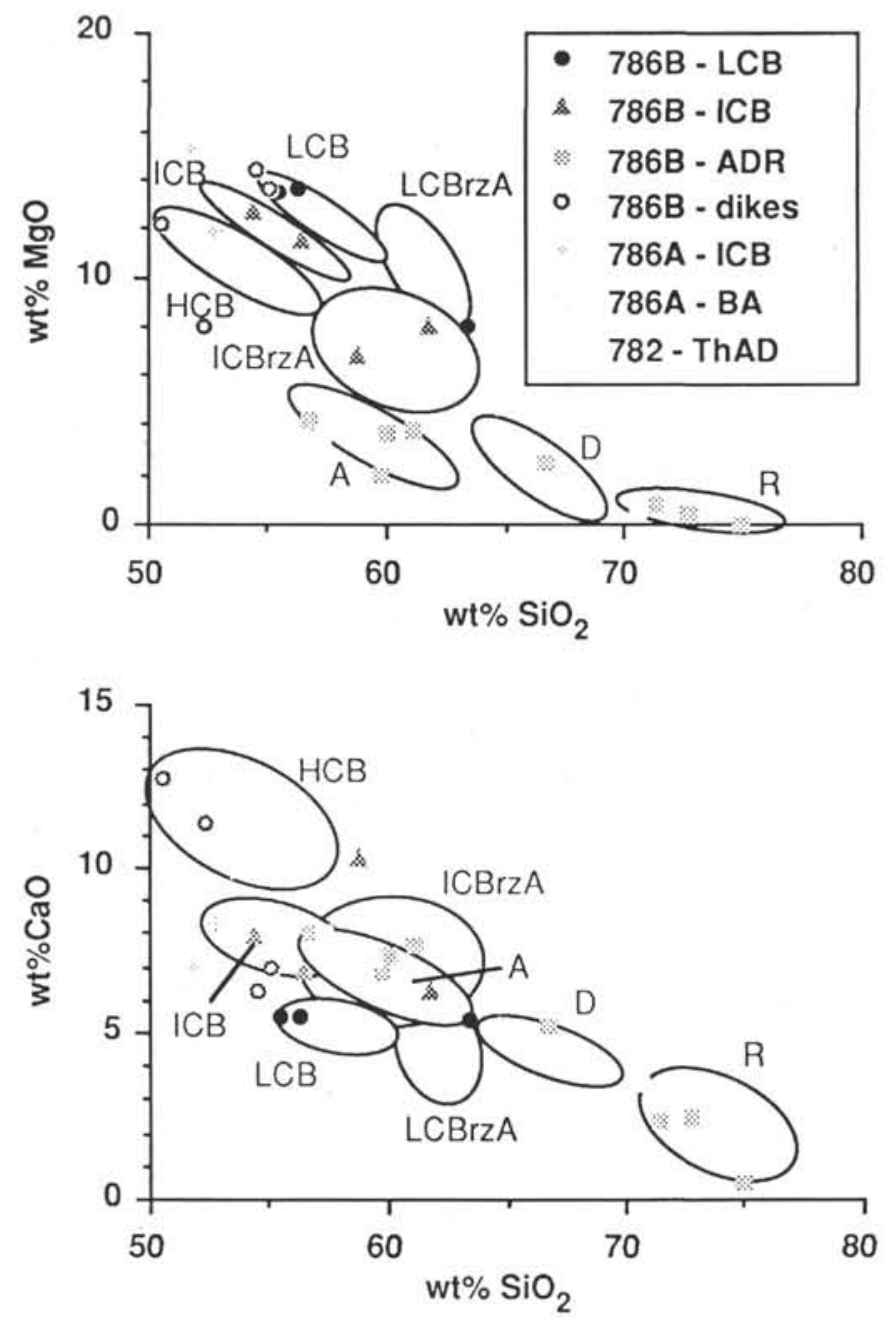

Figure 3. Classification of samples chosen for isotopic analysis using the projections of Arculus et al. (this volume). Fields on the diagram are: $\mathrm{LCB}=$ low-Ca boninite; $\mathrm{LCBrzA}=$ low-Ca bronzite andesite; $\mathrm{ICB}=$ intermediate-Ca boninite; ICBrZA = intermediate-Ca bronzite andesite; $\mathrm{HCB}=$ high-Ca boninite; $\mathrm{A}=$ andesite; $\mathrm{D}=$ dacite; $\mathrm{R}=$ rhyolite. For details on the key, see the text.

groups do not differ significantly from those of the unenriched samples $(6.95,6.86$, and 6.94 for the enriched compared with 7.02, $6.96,6.91,6.95$, and 6.76 for the unenriched). Any effect of alteration on the $\varepsilon \mathrm{Nd}$ values thus appears to have been small compared with the primary magmatic variations. This must indicate either that Ndenichment is a very localized phenomenon (e.g., from the rim to core of a clast) or that the fluids involved in the alteration circulated through rock of very similar composition. The inference in either case is that the $\varepsilon \mathrm{Nd}$ values can be treated as close to primary values, even in the LREE-enriched samples.

The $\mathrm{Th}-\mathrm{Zr}$ diagram in Figure $4 \mathrm{C}$ shows a significant positive correlation for all samples from Site 786. Samples from Site 782 have a similar correlation but are displaced to lower Th values for a given $\mathrm{Zr}$ content. The magnitude of the scatter is consistent with analytical error and pyroxene cumulation, suggesting that $\mathrm{Th}$ as well as $\mathrm{Zr}$ has behaved as an immobile element. This enables the chemically more appropriate element, $\mathrm{Th}$, to be used instead of $\mathrm{Zr}$ for assessing the mobility of $\mathrm{Pb}$ and $\mathrm{U}$.

$\mathrm{The} \mathrm{Pb}$ - Th plot is shown in Figure 4D. The large scatter, well in excess of analytical error, suggests that $\mathrm{Pb}$ has been mobilized during alteration. Because $\mathrm{Pb}$ is less incompatible than Th, the Hole 786B samples should follow a positive, shallow trend on this diagram. The equation for this trend cannot be defined precisely, but is taken from the diagram as $\mathrm{Pb}$ $=2 \times \mathrm{Th}+1$. The late dikes and boninites from Hole 786A and the Site 782 tholeiites have been assumed to follow primary trends of $\mathrm{Pb}=4 \times \mathrm{Th}$ and $\mathrm{Pb}=8 \times \mathrm{Th}$ respectively. These equations were used in the recalculation of $\mathrm{Pb}$ isotope ratios in Table 3 . The most noticeable changes in $\mathrm{Pb}$ concentration appear to have taken place near the base of Hole 786B. This is particularly true of the low-Ca bronzite-andesite dikes, where significant enrichment has taken place (compare for example the high $\mathrm{Pb}$ concentration in the sample from Core 70R-1 with the much lower $\mathrm{Pb}$ concentration in the sample from Core 62R-3 in Table 1). The two basaltic andesites from Hole $786 \mathrm{~A}$ have the highest $\mathrm{Pb} / \mathrm{Th}$ ratios. Because they are clasts within pelagic and volcanogenic sediments that have experienced alteration, it is most unlikely that their $\mathrm{Pb}$ contents are primary. The ratios chosen for the tholeiitic andesites are assumed also to apply to these rocks.

As far as isotope ratios are concerned, there is again little obvious difference in lead isotope ratios between more and less altered samples. For example, the sample from Core 70R-1 (Pb-enriched) is within error of that from Core 62R-3. The samples from Cores 8R-1, 21R-1, and 51R-1, all of which were enriched in LREEs, have similar $\mathrm{Pb}$-isotope ratios to those showing no enrichment. Again, therefore, the $\mathrm{Pb}$ isotope ratios are taken as primary, with the exception of the sample from Core 57R-4 as discussed above.

Figure 4E shows the U-Th covariation. A significant number of samples have experienced enrichment or depletion in excess of analytical error, indicating that $U$ has been highly mobile during alteration-a predictable observation in view of the known mobility of $\mathrm{U}$ during oxidative alteration. It is, however, possible to define an approximate primary trend of increasing Th and $\mathrm{U}$. The primary $\mathrm{Th} / \mathrm{U}$ ratios are taken as 2.0 for the $41 \mathrm{Ma}$ samples from the boninite edifice, and 1.5 for other samples. These ratios were used in the recalculation of $\mathrm{Pb}$ isotopes in Table 3.

\section{ISOTOPE SYSTEMATICS \\ Nd-Sr Isotope Covariations}

Figure 5A shows the distribution of data points from Sites 782 and 786 on an $\varepsilon$ Nd- $\varepsilon$ Sr covariation diagram. For comparison, we have also plotted a number of reference points and fields on this and subsequent figures. The range of oceanic mantle compositions is represented by the four "end-members" postulated by Zindler and Hart (1986), namely depleted MORB mantle, high U/Pb mantle (HIMU), and two enriched mantle components (EMI and EMII). The enriched components are represented as arrows rather than points because they are vectors rather than precise compositions. The depleted MORB mantle is represented by average Pacific MORB Mantle (PMM) and Indian MORB Mantle (IMM), and a field for Pacific MORB Mantle has also been drawn using the MORB data of White et al. (1987). Subducted sediments are represented by a field of Pacific Pelagic Sediment (PPS) and an average Pacific Volcanogenic Sediment (PVS) from the data of Woodhead (1989) and Ben Othman et al. (1989). Regional plume compositions are represented by the two closest large regional hotspots of Kerguelen (Dosso and Murthy, 1980) and Hawaii (Staudigel et al., 1984). Note that both hotspots are included because the Western Pacific Eocene terrane falls between the Indian and Pacific isotopic provinces and could, in theory, have been influenced by the isotopic composition of either province. Data from the Caroline Islands, the nearest seamount chain to the Bonin-Mariana system, lie within the Hawaii field (Hart, 1988) and therefore have not been plotted separately. Bulk Silicate Earth (BSE) has also been plotted. The fields drawn approximate to $90 \%$ probability contours and outliers (such as basalts from ridge segments adjacent to hotspots in the PMM group) have been omitted.

This diagram shows that, on this scale, the Leg 125 lavas and dikes form a well-defined cluster with a main axis of dispersion subparallel to a line through PMM and PVS (equivalent to the "mantle array"), although displaced to higher $\varepsilon \mathrm{Sr}$ values. The ranges of $\varepsilon \mathrm{Sr}$ and $\varepsilon \mathrm{Nd}$ 

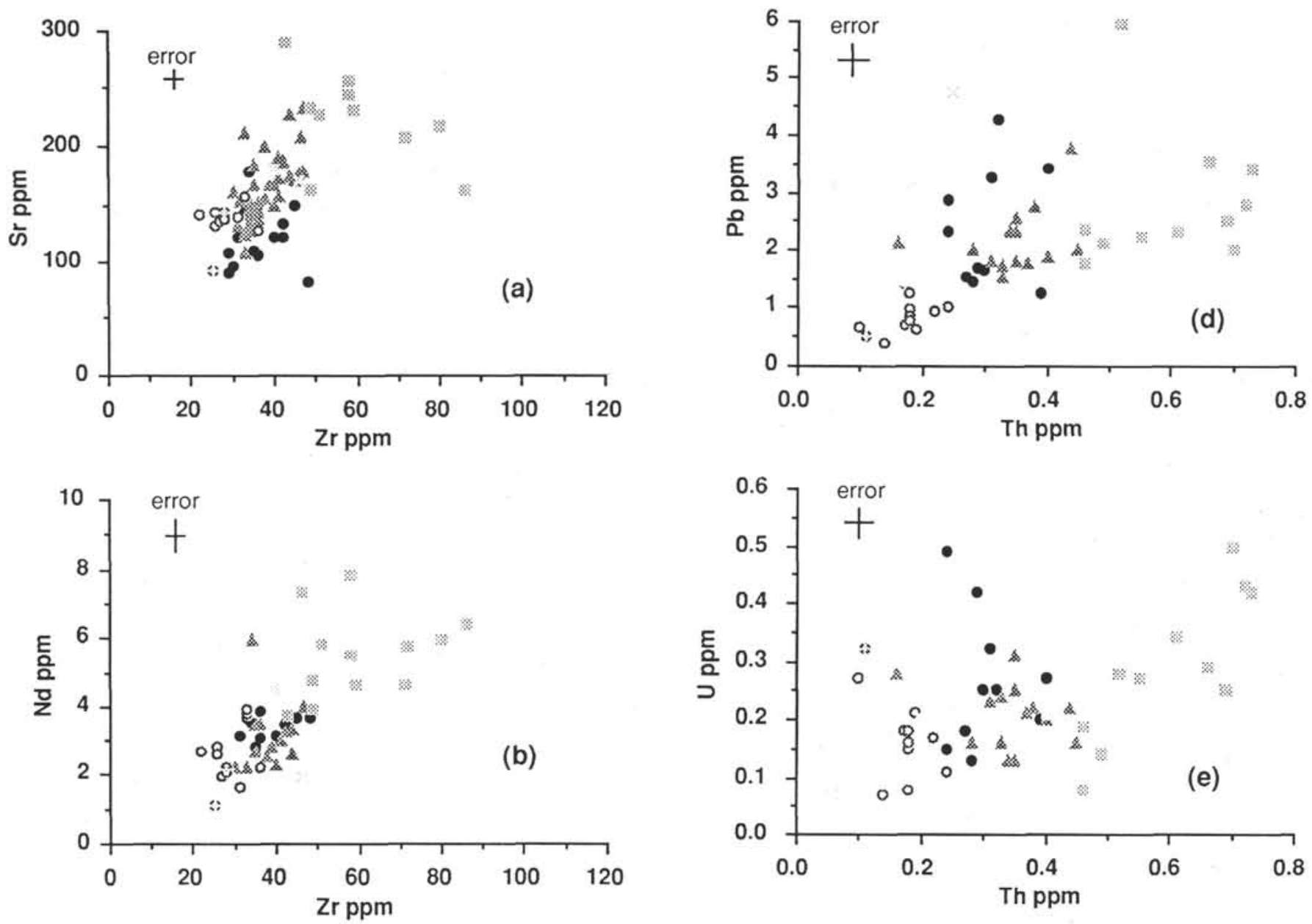

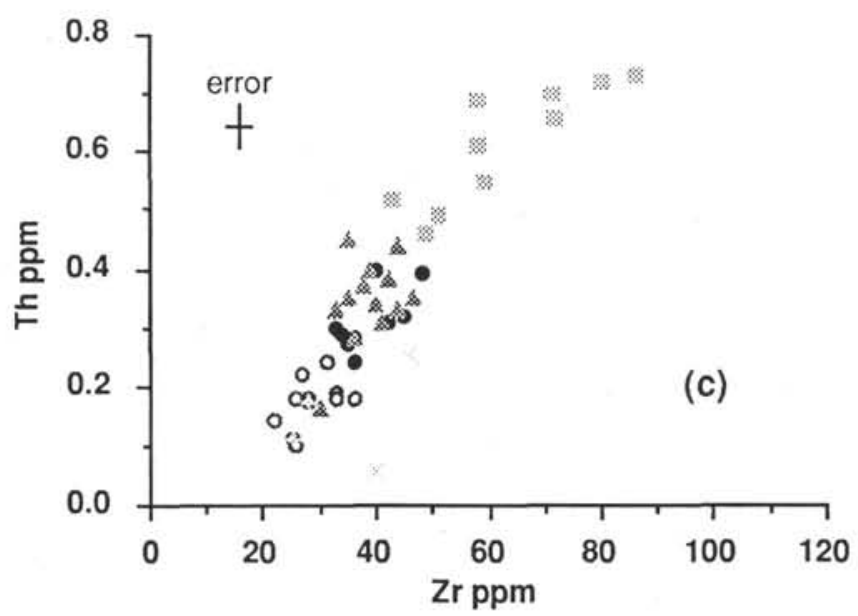

Figure 4. Trace element covariation diagrams to highlight the effects of alteration on the elements related to the $\mathrm{Sr}, \mathrm{Nd}$, and $\mathrm{Pb}$ isotope systems.

values are broadly comparable to those of Hawaiian lavas, although they have higher $\varepsilon$ Sr values and higher $\varepsilon N d$ values than an average Hawaiian basalt.

The distribution of Leg 125 data is shown in more detail on the expanded diagram in Figure 5B. It is apparent that the data form several distinct groupings. The LCB group has the most radiogenic $\mathrm{Sr}$ isotope ratios. The two samples that make up this group, one a boninite, the other

\section{Key to symbols}

$$
\begin{aligned}
& \text {-786B - Low-Ca boninite group } \\
& \text { 786B - Intermediate-Ca boninite group } \\
& \text { 786B - Andesite-dacite-rhyolite group } \\
& \text {-786B - Late boninite dikes } \\
& \text { 786A - Intermediate-Ca boninites } \\
& \text { 786A - Basaltic andesites } \\
& 782 \text { - Tholeiitic andesites and dacites }
\end{aligned}
$$

Figure 4 (continued).

a bronzite andesite, are identical within analytical error. The 786B$\mathrm{ICB}$ and $-\mathrm{ADR}$ groups form a single cluster, displaced to lower $\varepsilon \mathrm{Sr}$ values and slightly higher $\varepsilon N d$ values than the LCB group. The ICB group does have consistently higher $\varepsilon N d$ values than the ADR group but the difference is close to the limits of experimental error and cannot be considered significant. The rock types that make up these two groups (intermediate-Ca boninites, intermediate-Ca bronzite andesites, andesites, and dacites) can therefore be considered co-genetic on this projection. Note that the rhyolites have $\varepsilon N d$ values of 6.98 and 7.26 , slightly higher than the andesites and dacites, but have not been plotted on this diagram because of the unreliability of the $\mathrm{Sr}$ isotope ratios. These values are not, 

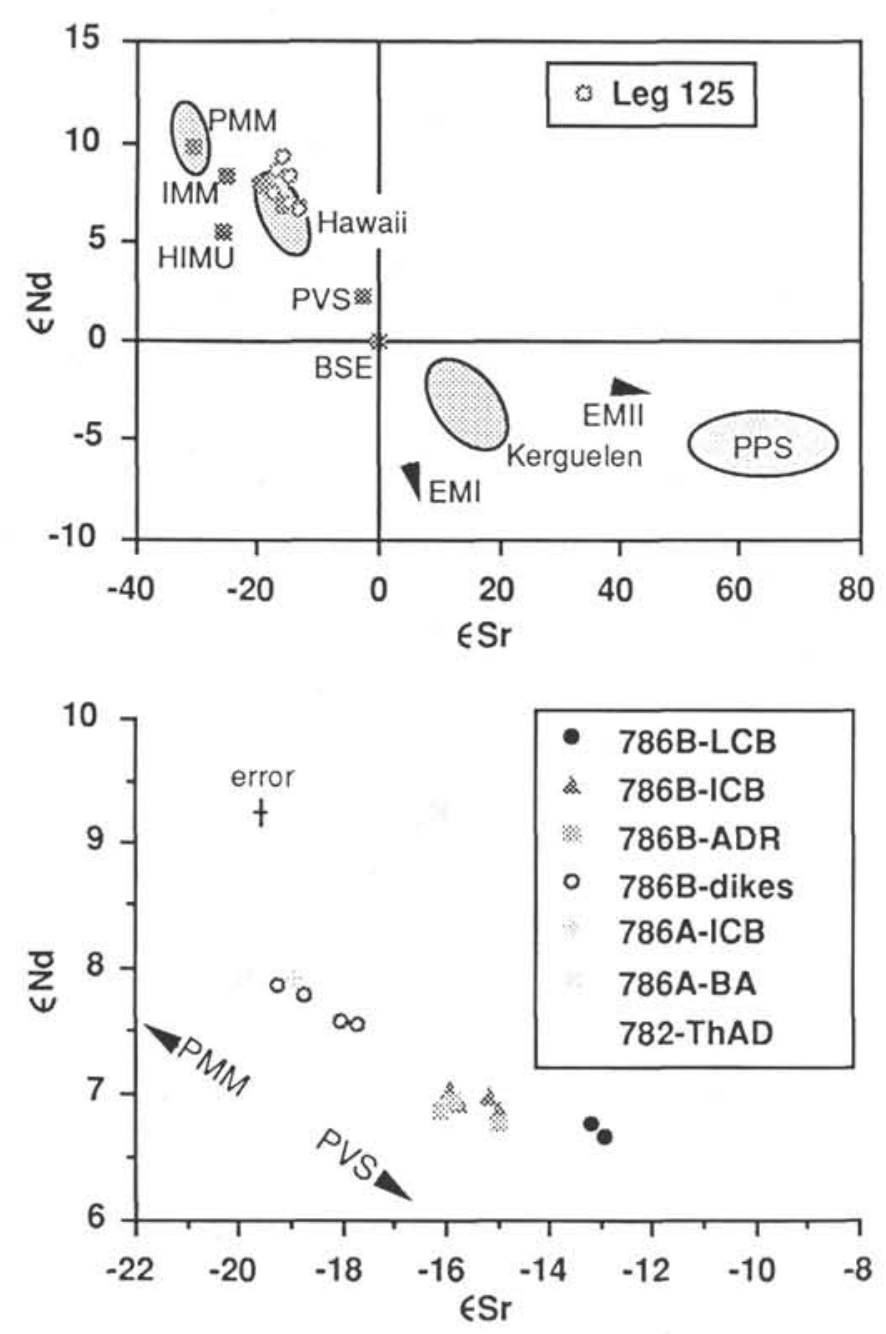

Figure 5. $\varepsilon \mathrm{Nd}-\varepsilon \mathrm{Sr}$ diagrams for Leg 125 samples. The upper figure (A)) shows the distribution of data points relative to the Hawaii and Kerguelen hotspots, Pacific MORB mantle (PMM), Bulk Silicate Earth (BSE), Pacific Pelagic Sediment (PPS), Pacific Volcanogenic Sediment (PVS), and the high- $\mu$ (HIMU), EMI and EMII mantle end-members. The lower figure (B) is an expansion of part of this diagram to highlight variations within the Leg 125 samples.

however, sufficiently different to suggest that the rhyolites had an origin other than by fractional crystallization from the andesites and dacites.

The boninitic late dikes from Hole 786B and lavas from Hole 786A (including the basaltic andesite from Core $12 \mathrm{X}-1$ ) form a distinct group subparallel to a PMM-PVS line. Of the dikes, the two intermediate-Ca boninites are those with the lowest $\varepsilon N d$ values. The high-Ca boninites and the lavas from Hole 786A have slightly higher $\varepsilon \mathrm{Nd}$ values. It is thus possible that some of the late dikes were feeders to the boninites at the top of the edifice. If the interpretation of the $\mathrm{K}$-Ar ages is correct, this process may have taken place some $6 \mathrm{Ma}$ after the formation of the main edifice. The trend followed by these samples can be extrapolated to the LCB group. The orientation of the trend is typical of that created by simple heterogeneities within the mantle array. The tholeiitic lavas from Site 782 and the basaltic andesite clast from Core $6 \mathrm{X}-5$ in Hole 786A have the highest $\varepsilon \mathrm{Nd}$ values and a significantly greater $\varepsilon S r$ shift from the PMM-PVS line. These characteristics resemble those from many oceanic island arcs, where they are generally interpreted in terms of enrichment of a depleted mantle source by seawater-derived Sr (e.g., Hawkesworth, 1982).

\section{Lead Isotope Covariations}

Figures $6 \mathrm{~A}$ and $6 \mathrm{D}$ show the variations in ${ }^{207} \mathrm{~Pb} /{ }^{204} \mathrm{~Pb}$ and ${ }^{208} \mathrm{~Pb} /{ }^{204} \mathrm{~Pb}$ isotope ratios relative to the ${ }^{206} \mathrm{~Pb} /{ }^{204} \mathrm{~Pb}$ ratio in the context of the isotope components and reference compositions plotted in Figure 5A. The figures also show the Northern Hemisphere Reference Line (NHRL) of Hart (1984), which is the best-fit line for the $\mathrm{Pb}$ isotope compositions for MORBs and a group of oceanic islands (Hawaii, Iceland, Azores, Canaries, Cape Verde, Galapagos, NE Pacific seamounts) in the Northern Hemisphere. Because of the problem, discussed earlier, of $\mathrm{Pb}$ and $\mathrm{U}$ mobility, these diagrams have been plotted both as initial ratios and as recalculated (alteration-corrected present-day) values. Note that there are slight differences of detail in the two sets of diagrams, but that the overall patterns are similar. It is apparent on both projections the bulk of the Leg 125 samples plot on or just below the NHRL but are displaced toward slightly more radiogenic compositions than PMM.

The Leg 125 samples, annotated according to lithostratigraphic group, are plotted on expanded scales on Figures 6B, C, E, and F. These plots show that the various magmatic groups are systematically displaced along the NHRL. The tholeiitic lavas from Site 782 have the least radiogenic compositions, followed by the late dikes and $786 \mathrm{~A}$ lavas, then the intermediate- $\mathrm{Ca}$ boninites and bronzite andesites and andesite-dacite lavas, and finally the low-Ca boninites and bronzite andesites which have the most radiogenic compositions. These diagrams thus confirm the groupings made on the basis of Figure 5B. The consistency of the data, in particular the similarities in isotope ratios between variably-altered samples from the same lithostratigraphic group, suggest that alteration effects are small compared with petrogenetic variations, although they may contribute to the scatter. Apart from the tholeiites from Site 782, the $\mathrm{Pb}$ isotope variations are not far in excess of that expected from the $2 \mathrm{~s} . \mathrm{d}$. reproducibility of the SRM981 analysis as denoted by the error bars in Figure 6. However, these standard data are a compilation of values produced by several analysts. The constant relationships between lithology and $\mathrm{Pb}$ isotope composition suggest that the analyses reported here are considerably more reproducible.

This dispersion along the NHRL has several possible explanations: that it is accidental; that it represents an isochron; or that it represents two-component mixing. The slope on the ${ }^{207} \mathrm{~Pb} /{ }^{204} \mathrm{~Pb}$ ${ }^{20} \mathrm{~Pb} /{ }^{204} \mathrm{~Pb}$ diagram corresponds to an apparent age of $1.65 \mathrm{Ga}$, too great an age for the $\mathrm{Pb}$ isotope variation to have developed as an isochron within oceanic lithosphere. The fact that the various magmatic groups plot in a consistent order on both these and the $\varepsilon \mathrm{Nd}-\varepsilon \mathrm{Sr}$ diagram indicates that the trend is unlikely to be accidental and is most likely to be explained by mixing of a less and a more radiogenic component. Since mixing is linear on Figure 6, two likely components are PMM and a component along the NHRL, possibly close to PVS. The latter does not imply that Pacific volcanogenic sediment was necessarily itself involved. The bulk of Pacific volcanogenic sediments are of Cretaceous age and derived from oceanic, intraplate volcanoes. The PVS composition can therefore also be considered a Pacific hotspot composition. Note that the data are consistent with the involvement of Pacific, rather than Indian or South Pacific, mantle. The latter plot above the NHRL on the ${ }^{208} \mathrm{~Pb} /{ }^{204} \mathrm{~Pb}-{ }^{206} \mathrm{~Pb} /{ }^{204} \mathrm{~Pb}$ diagram.

The lead isotope plots also demonstrate the absence of a significant pelagic sediment component in most of the Leg 125 samples as this would cause a displacement to high ${ }^{208} \mathrm{~Pb} /{ }^{204} \mathrm{~Pb}$ and ${ }^{207} \mathrm{~Pb} /{ }^{204} \mathrm{~Pb}$ ratios at a given ${ }^{206} \mathrm{~Pb} /{ }^{204} \mathrm{~Pb}$ ratio. This is true of the tholeitic lavas from Site 782 as well as the boninites from Site 786. It is also a common feature of Eocene lavas from the Mariana forearc (HickeyVargas, 1989; Stern et al., 1991). It is an enigma that these boninites, apparently erupted above a subduction zone, do not exhibit this common characteristic of subduction-related lavas. Pacific volcanogenic sediments do, however, lie along the NHRL and could be the source of a subduction component. The two notable exceptions from this study are the samples from Cores $12 \mathrm{X}-1$ and $6 \mathrm{X}-5$, which 
A
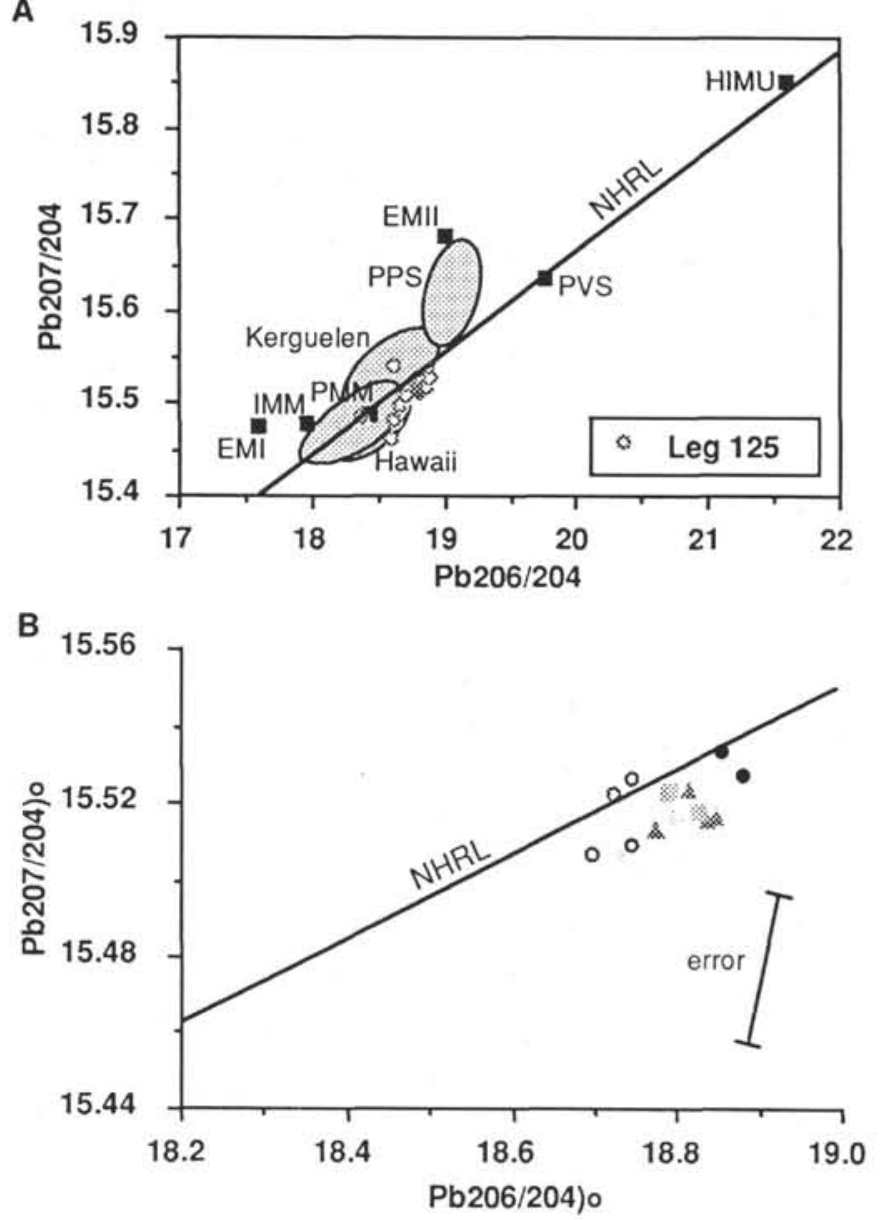

C

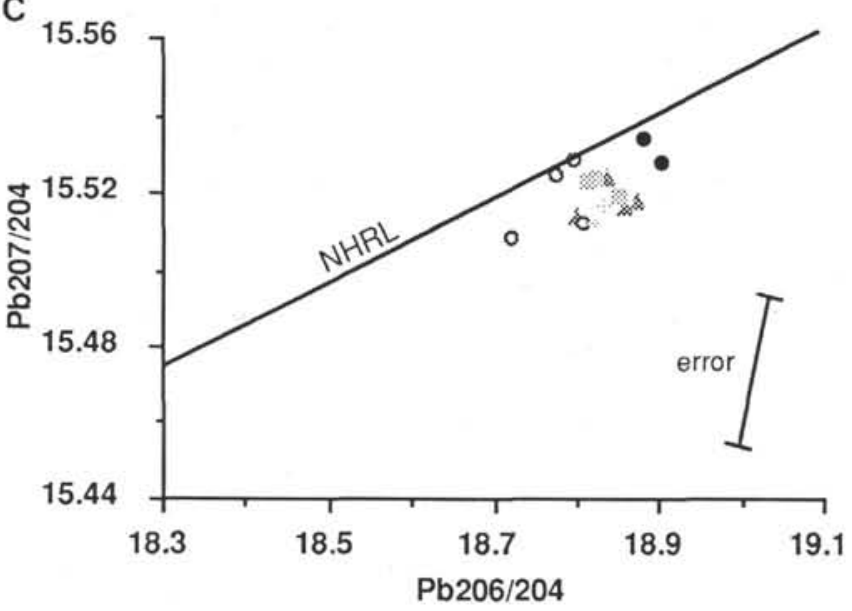

Figure 6. Diagrams showing $\mathrm{Pb}$ isotope variations in Leg 125 samples. A, B, and $\mathbf{C}$ show ${ }^{207} \mathrm{~Pb} /{ }^{204} \mathrm{~Pb}$ vs. ${ }^{206} \mathrm{~Pb} /{ }^{204} \mathrm{~Pb}$ covariations. A shows the distribution of data points on the scale of global variations. $\mathbf{B}$ and $\mathbf{C}$ are an expansion of part of this diagram to highlight variations within the Leg 125 samples. D, E, and $\mathbf{F}$ show ${ }^{208} \mathrm{~Pb} /{ }^{204} \mathrm{~Pb}$ vs. ${ }^{206} \mathrm{~Pb} /{ }^{204} \mathrm{~Pb}$ covariations. D shows the distribution of data points on the scale of global variations. $\mathbf{E}$ and $\mathbf{F}$ are an expansion of part of this diagram to highlight variations within the Leg 125 samples. Fields and terms are identified in the caption to Figure 5 except NHRL (Northern Hemisphere Reference Line). The ratios with subscript "o" are initial ratios, those with subscript " $\mathrm{r}$ " are present-day ratios recalculated to take alteration into account.
D

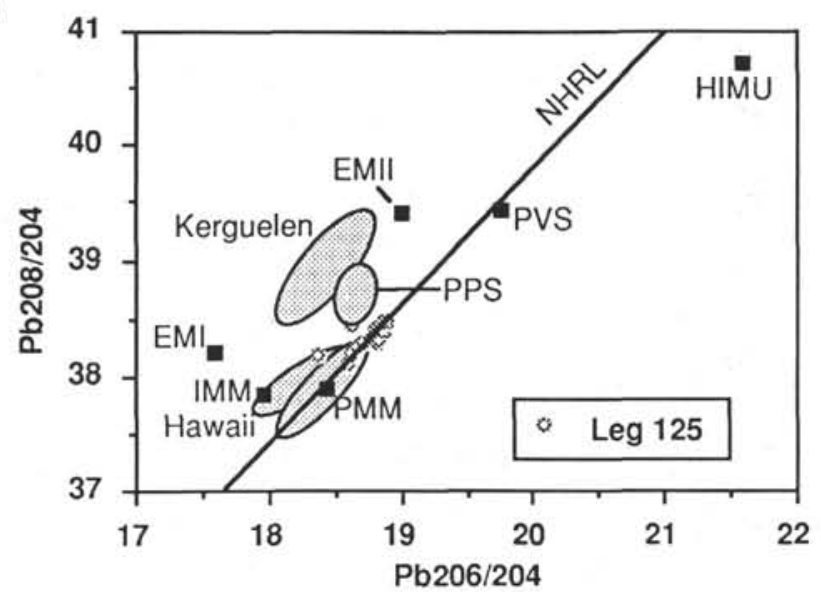

E

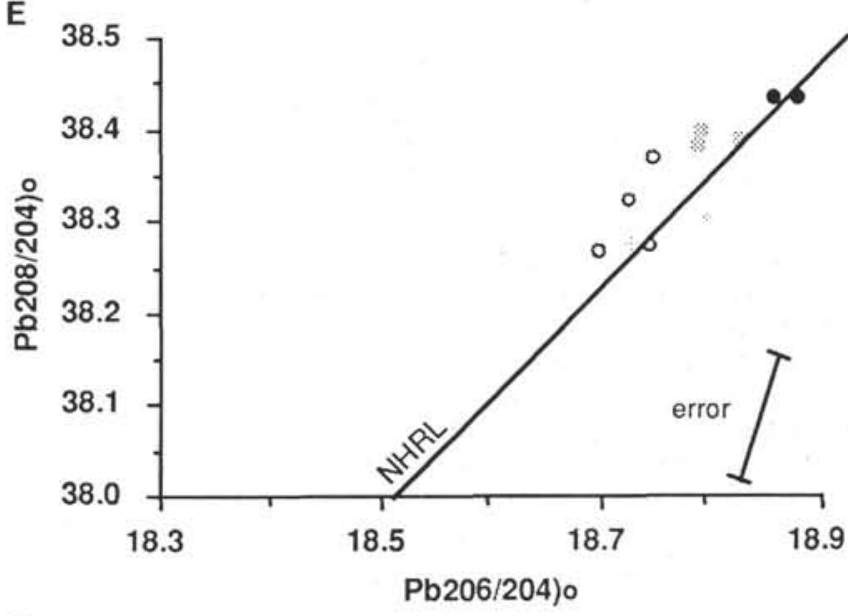

$\mathrm{F}$

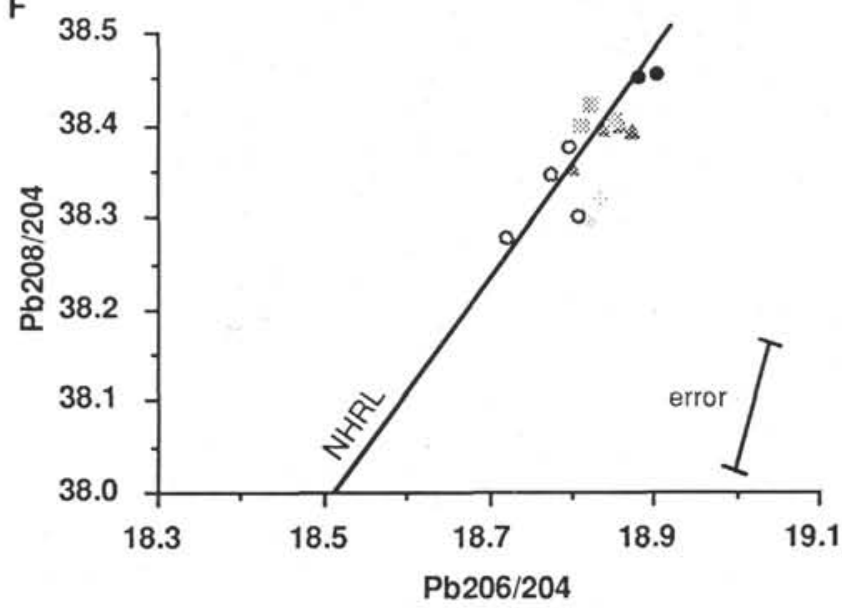

Figure 6 (continued).

are displaced toward PPS. These are the youngest samples, and this observation could therefore be taken to indicate a recent input of subducted pelagic lead into the mantle source. However, both are clasts within sediment containing a pelagic component and have experienced extensive alteration and probable $\mathrm{Pb}$ enrichment. $\mathrm{Al}-$ though lavas and dikes within the edifice may also have experienced $\mathrm{Pb}$ enrichment, the source of the lead in these samples would have been surrounding lavas of similar isotopic composition. By contrast, the lead in the two anomalous samples most probably would have 


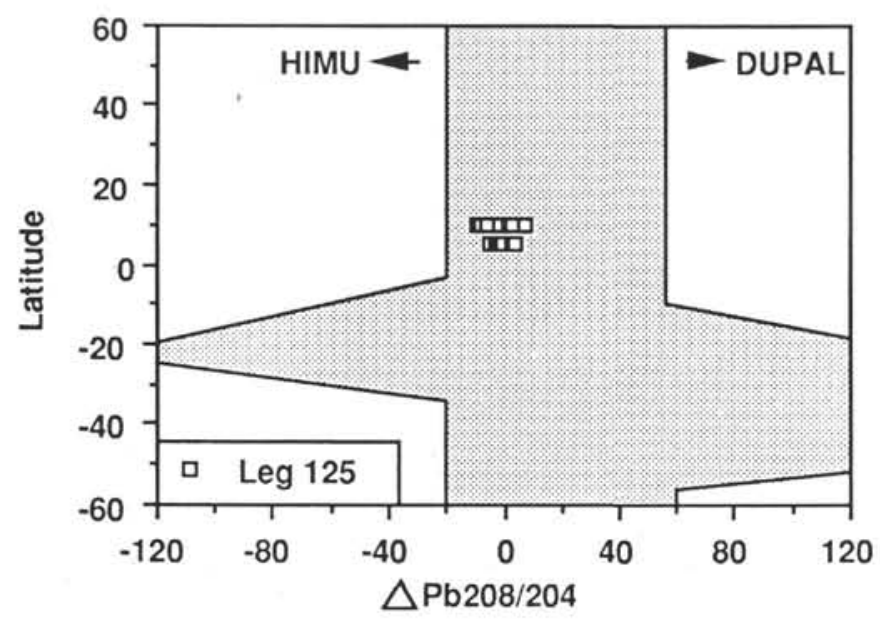

Figure 7. $\mathrm{Pb}$ isotopic composition of Eocene-Oligocene Leg 125 samples plotted as a function of latitude, assuming values of $5^{\circ} \mathrm{N}$ for Eocene (41 Ma) and $10^{\circ} \mathrm{N}$ for Oligocene ( $35 \mathrm{Ma}$ ) groups. The shaded area is that of suboceanic mantle unrelated to subduction as defined by Hart (1988).

been derived from the pore waters of the enclosing pelagic sediment. The isotope variations themselves do not, however, enable subducted lead to be distinguished from the effects of alteration.

Apart from the two samples with the pelagic sediment lead signature, the samples have $\Delta \nabla / 4$ and $\Delta 8 / 4$ values (a measure of the deviation from the NHRL) of abour -5 to +3 and -10 to +7 respectively (see Table 3). Reconstruction of the global setting of the Izu-Bonin forearc from Eocene to Recent (see references in Pearce et al., this volume) shows that the Leg 125 sites would have lain at the equator or slightly further north in the Eocene. The isotope data thus lie well within the range of delta values for ocean island basalts of this latitude, as compiled by Hart (1984) (Fig. 7).

The plot of ${ }^{207} \mathrm{~Pb} /{ }^{204} \mathrm{~Pb}$ against ${ }^{208} \mathrm{~Pb} /{ }^{204} \mathrm{~Pb}$ has been shown separately in Figure 8. On the scale of Figure 8A, they form a trend at an acute angle to the NHRL toward an enriched composition in the region of PPS. On this projection, the samples containing an apparent sediment component do not separate because the sediment component and the other enriched component are co-linear.

On the detailed scale of Figure 8B, the Leg 125 samples can be seen to form two distinct subparallel trends. The lower trend, displaced to a higher ${ }^{208} \mathrm{~Pb} /{ }^{204} \mathrm{~Pb}$ ratio, is followed by the $41 \mathrm{Ma}$ lavas and dikes from the main boninite edifice in Hole 786B. The other trend is followed by the late dikes from Hole 786B, lavas from Hole 786A, and forearc tholeiites from Hole 782. As in Figure 6, the trends on this diagram can be viewed as accidental, time-related, or the product of component mixing. If the two distinct trends are accidental, the likely cause is fractionation in the mass spectrometer. The error of $0.05 \% / \mathrm{amu}$ is not large in absolute terms but becomes significant because of the small variations in ${ }^{207} \mathrm{~Pb} /{ }^{204} \mathrm{~Pb}$ ratios between the magma types. The error bar is oriented in the directions of the two parallel trends, indicating that variations within each of the two groups may be explained in part by analytical error, but that the variations between the two groups are likely to be real. Note that the variations are unlikely to be caused by systematic errors because the two groups of samples were analyzed together. If the difference between the two trends is to be interpreted as time-related, this cannot be caused by variations in $\mathrm{Th} / \mathrm{Pb}$ within a single source because the older (41 Ma) samples have lower $\mathrm{Th} / \mathrm{Pb}$ ratios yet higher ${ }^{208} \mathrm{~Pb} /{ }^{204} \mathrm{~Pb}$ ratios. In order to obtain the observed trends, it is necessary to postulate that the source of the edifice lavas did have a lower $\mathrm{Th} / \mathrm{Pb}$ ratio, but that this has been masked by recent mixing and partial melting events. Mixing is also, therefore, a necessary part of this hypothesis. Differences in $\mathrm{U} / \mathrm{Pb}$ ratios could generate the difference
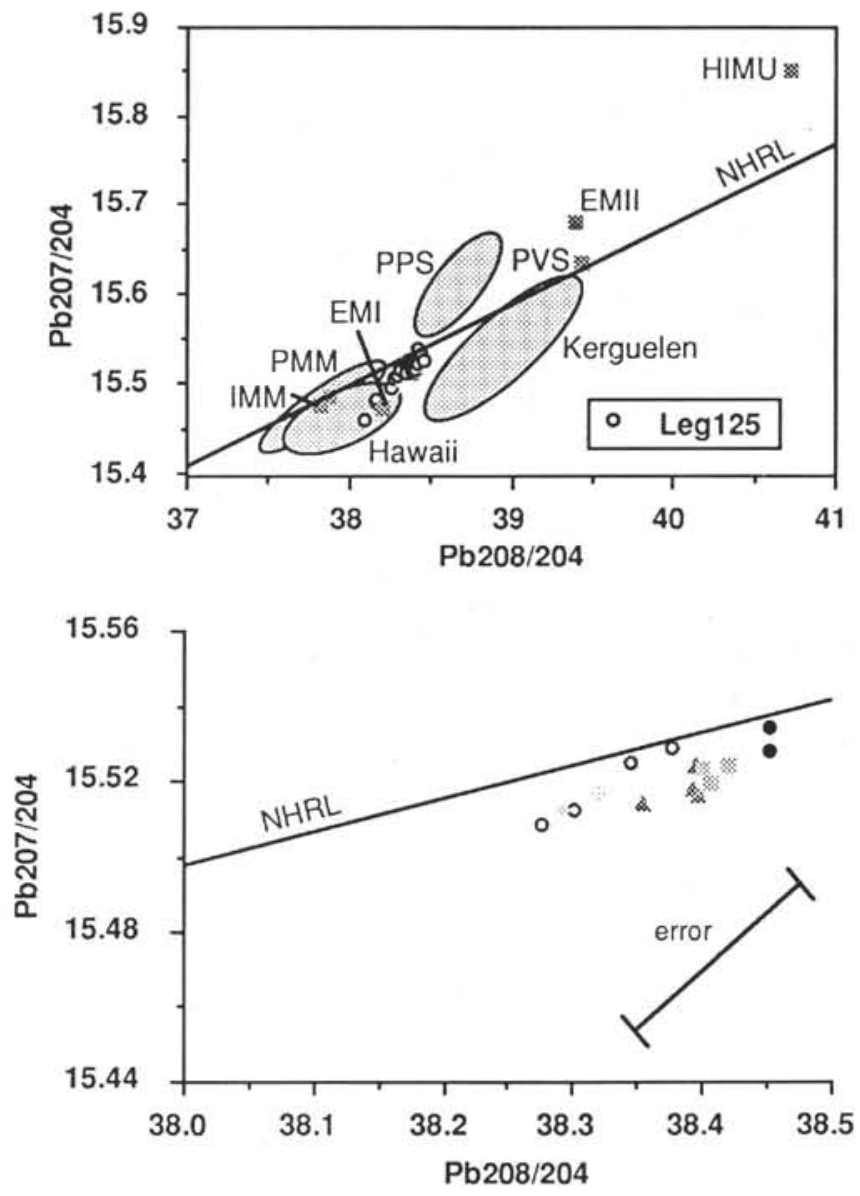

Figure 8. Diagrams showing ${ }^{208} \mathrm{~Pb} /{ }^{204} \mathrm{~Pb}$ vs. ${ }^{207} \mathrm{~Pb} /{ }^{204} \mathrm{~Pb}$ covariations. A shows the distribution of data points on the scale of global variations. $\mathbf{B}$ is an expansion of part of this diagram to highlight variations within the Leg 125 samples. Fields and terms are identified in the captions to Figures 5 and 6.

in ${ }^{207} \mathrm{~Pb} /{ }^{204} \mathrm{~Pb}$ ratios in about $120 \mathrm{Ma}$ (for $\mu=16.5$ ), but this should then also be apparent in projections using the ${ }^{206} \mathrm{~Pb} / 204 \mathrm{~Pb}$ ratio. In order to explain the two trends by mixing, one component would need to have a composition of about $38.1,15.46$, and the other would have to comprise a mixture of PPS and PVS. This is not, however, consistent with the plot of ${ }^{208} \mathrm{~Pb} /{ }^{204} \mathrm{~Pb}$ against ${ }^{206} \mathrm{~Pb} / 204 \mathrm{~Pb}$, which shows no component in the direction of PPS.

The preferred explanation is therefore that the subparallel trends are largely the result of fractionation in the mass spectrometer, but that the presence of two trends does imply two boninite groups (one containing 41 Ma edifice rocks from Hole $786 \mathrm{~B}$, the other containing late dikes from Hole $786 \mathrm{~B}$ and lavas from Hole 786A) as seen on the $\varepsilon \mathrm{Nd}-\varepsilon \mathrm{Sr}$ diagram in Figure 5. Without the effects of fractionation, these would have plotted along the NHRL with the 41 Ma edifice lavas being the more radiogenic. The plot would then have resembled that of ${ }^{208} \mathrm{~Pb} /{ }^{204} \mathrm{~Pb}$ against ${ }^{206} \mathrm{~Pb} /{ }^{204} \mathrm{~Pb}$. By the same argument, fractionation has increased the scatter below the NHRL on the diagram of ${ }^{207} \mathrm{~Pb} /{ }^{204} \mathrm{~Pb}$ against ${ }^{206} \mathrm{~Pb} /{ }^{204} \mathrm{~Pb}$. Overall, therefore, the Leg 125 samples are remarkable for their coincidence with the NHRL in all projections.

\section{$\mathrm{Sr}-\mathrm{Pb}$ and $\mathrm{Nd}-\mathrm{Pb}$ Isotope Covariations}

The relationships between $\varepsilon \mathrm{Sr}, \varepsilon \mathrm{Nd}$, and the ${ }^{206} \mathrm{~Pb} /{ }^{204} \mathrm{~Pb}$ ratio are shown in Figure 9. The $\varepsilon \mathrm{Nd}-{ }^{206} \mathrm{~Pb} /{ }^{204} \mathrm{~Pb}$ diagram shows the data plotting in a consistent order between PMM and PVS, indicating that almost all the data plot on a single two-component mixing trend between PMM and $\mathrm{PVS}$ in $\varepsilon \mathrm{Nd}-\mathrm{Pb}$ isotope space. The two basaltic andesite clasts from 

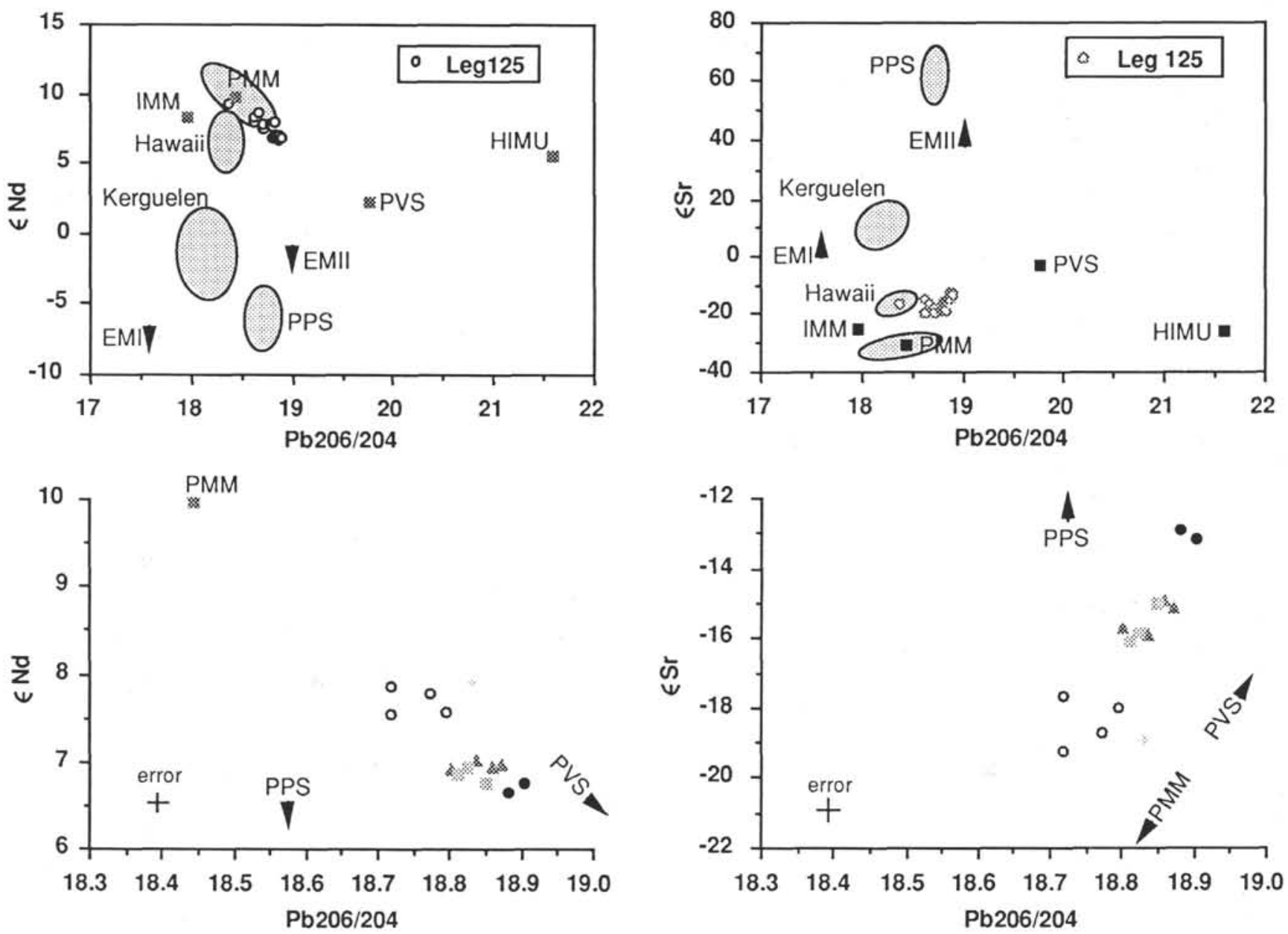

Figure 9. Diagrams showing $\varepsilon \mathrm{Sr}$ and $\varepsilon$ Nd against ${ }^{206} \mathrm{~Pb} /{ }^{204} \mathrm{~Pb}$. $\mathbf{A}$ and $\mathbf{B}$ show $\varepsilon N d v s{ }^{206} \mathrm{~Pb} /{ }^{204} \mathrm{~Pb}$ covariations. A shows the distribution of data points on the scale of global variations. $\mathbf{B}$ is an expansion of part of this diagram to highlight variations within the Leg 125 samples. The right-hand diagrams show $\varepsilon \mathrm{Sr}$ vs. ${ }^{206} \mathrm{~Pb} /{ }^{204} \mathrm{~Pb}$ covariations. $\mathrm{C}$ shows the distribution of data points on the scale of global variations. $\mathbf{D}$ is an expansion of part of this diagram to highlight variations within the Leg 125 samples. Fields and terms are identified in the captions to Figures 5 and 6.

Hole 786A plot slightly off this trend because of alteration or a subducted pelagic sediment component, as discussed earlier. Because $\varepsilon$ Nd behaves coherently with the lead isotopes, the $\varepsilon \mathrm{Sr}^{206} \mathrm{~Pb} /{ }^{204} \mathrm{~Pb}$ diagram resembles the $\varepsilon N d-\varepsilon$ Sr diagram of Figure 5. Most samples form a trend parallel to a line joining PMM and PVS, but displaced to higher $\varepsilon \mathrm{Sr}$ values. The tholeiites and the younger basaltic andesite plot off the trend to still higher $\varepsilon$ Sr values. These tholeiites did, however, plot on the two-component $\mathrm{Nd}$ and $\mathrm{Pb}$ isotope mixing line. Thus, although $\mathrm{Nd}$ and $\mathrm{Pb}$ isotopes show coherent behavior, it is possible that $\mathrm{Sr}$ isotopes provide evidence for an additional, possibly seawater-derived, component in the mantle source.

We can therefore conclude from the isotope diagrams that most of the Eocene-Oligocene boninites plot on simple two-component mixing trends between Pacific MORB mantle (PMM) and Pacific Volcanogenic Sediment (PVS). The tholeiites from Site 782 plot closest to PMM, the boninitic edifice in Hole 786B plots closest to PVS, and the late dikes in Hole 786B together with the lavas from Site 786A occupy an intermediate position. A shift to higher $\varepsilon \mathrm{Sr}$ values may indicate the involvement of an additional, possibly seawaterderived, component. The shift of the two basaltic andesite clasts toward pelagic sediment lead compositions may indicate a further component or may be the result of alteration by sedimentary pore fluids. These infer-

Figure 9 (continued).

ences, and the relationships between the boninites and the tholeites, are now investigated further on isotope-trace element diagrams.

\section{ISOTOPE-TRACE ELEMENT COVARIATIONS}

The previous section has shown that the $\mathrm{Nd}$ and $\mathrm{Pb}$ isotopes behave coherently in the Leg 125 samples and therefore that only one isotope is needed to represent the variation from the depleted to the enriched component. $\varepsilon$ Nd has been selected because of its higher variability relative to analytical precision and is plotted against a series of trace element ratios in Figure 10. The elements are plotted as ratios to reduce the effects of partial melting, fractional crystallization, and alteration. Ideally, $\mathrm{Nd}$ would be used as the denominator because this would create linear mixing lines on the diagrams. However, the proven mobility of the REEs precludes this option, as Figure 4 demonstrated. $\mathrm{Zr}$ is therefore used instead as the denominator, having been shown to have been immobile and to have exhibited a petrogenetic behavior closer to that of $\mathrm{Nd}$ than the other immobile elements ( $\mathrm{Ti}, \mathrm{Th}$, and $\mathrm{Nb}$ ). The data plotted have been screened to exclude ratios on samples known to have been strongly affected by alteration (for $\mathrm{Pb}, \mathrm{Y}, \mathrm{Sr}$, and REEs) or fractionation (for $\mathrm{Sr}$ and $\mathrm{Ti}$ ).

The five diagrams in Figure 10 , based on the $\mathrm{Ti} / \mathrm{Zr}, \mathrm{Y} / \mathrm{Zr}, \mathrm{Nb} / \mathrm{Zr}$, $\mathrm{Pb} / \mathrm{Zr}$, and $\mathrm{Th} / \mathrm{Zr}$ ratios, confirm the evidence from isotope covariation diagrams that the magmatic groups from Leg 125 can be explained in terms of simple two-component mixing, at least to a first approximation. For this, they satisfy the criteria of (1) forming curvilinear trends within the limits of experimental error, partial melting and fractional crystallization, and (2) following a consistent order regardless of the isotope or trace element ratio used. The 

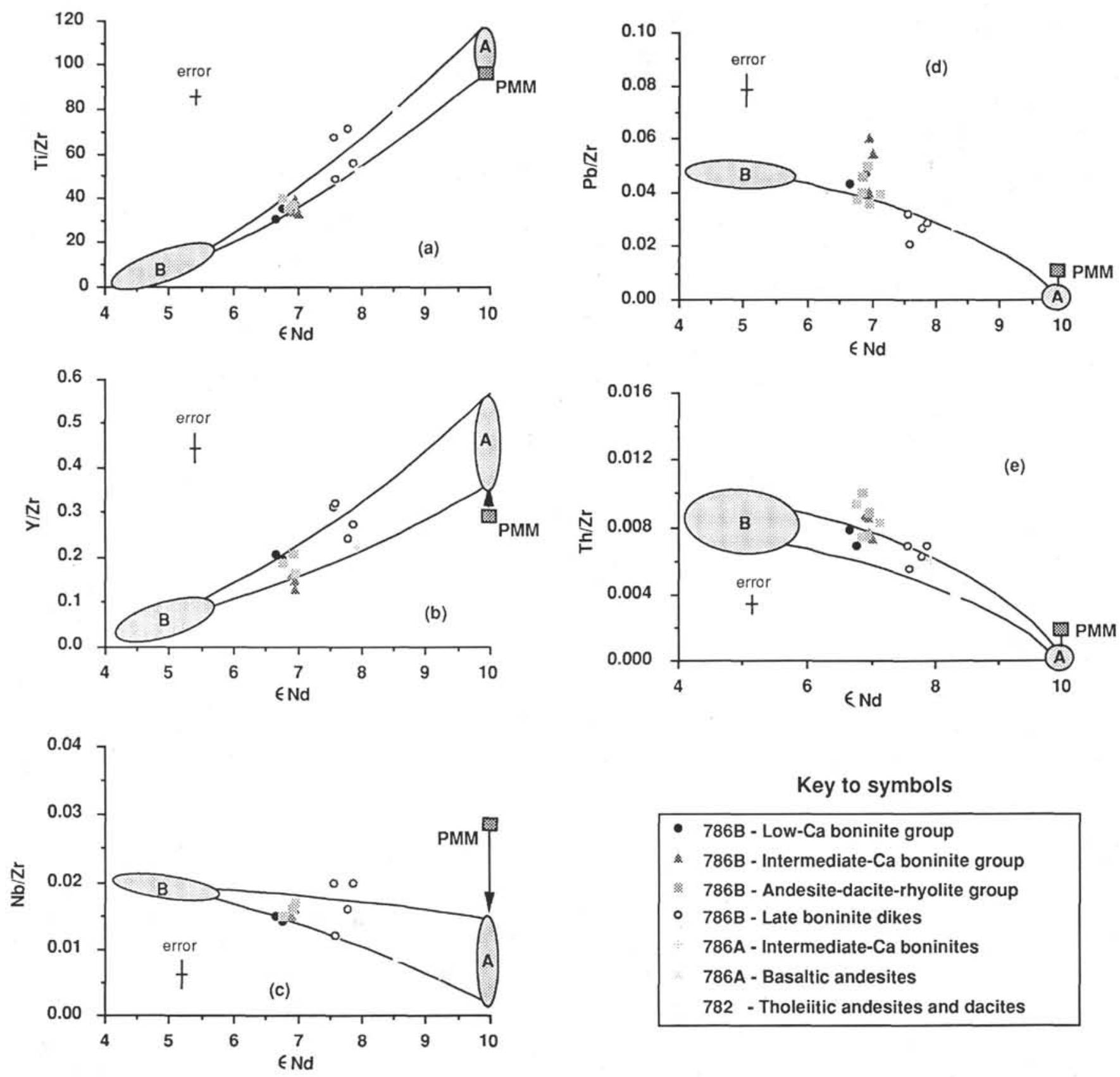

\section{Key to symbols}

Figure 10. Plots of (A) $\mathrm{Ti} / \mathrm{Zr}$, (B) $\mathrm{Y} / \mathrm{Zr}$, (C) $\mathrm{Nb} / \mathrm{Zr}$, (D) $\mathrm{Pb} / \mathrm{Zr}$, and (E) $\mathrm{Th} / \mathrm{Zr}$ against $\varepsilon N d$. $P M M=$ Pacific MORB mantle. Fields shown are approximate possible ranges for inferred components $\mathrm{A}$ and $\mathrm{B}$. Curved lines are mixing lines between these components assuming $\mathrm{Nd} / \mathrm{Zr}=0.12$ in component $\mathrm{A}$ and 0.06 in component $\mathbf{B}$.

isotopically-depleted and -enriched end-members have been designated " $A$ " and " $B$ " respectively. The curvature of the mixing lines depends on the $\mathrm{Nd} / \mathrm{Zr}$ ratios of these two end members. On the basis of the $\varepsilon \mathrm{Nd}-\mathrm{Nd} / \mathrm{Zr}$ diagram in Figure 11, the mixing curves are based on ratios of 0.12 in component $\mathrm{A}$ and 0.06 in component B.

Component $\mathrm{A}$ is characterized by high $\varepsilon \mathrm{Nd}$. There are no constraints on the precise isotopic composition of this component, so a $\mathrm{PMM}$ value of +10 is assumed. The trace element ratios of component A are then read off the mixing curves at $\varepsilon N d=10$. However, with the possible exception of $\mathrm{Ti} / \mathrm{Zr}$, none of the trace element ratios correspond to the PMM composition, even if the $\varepsilon N d$ value of component $\mathrm{A}$ is taken from the lower ( $\mathrm{ca} \mathrm{8)}$ or higher (ca 12) extremes of

Figure 10 (continued).

the PMM range. This observation suggests that component $\mathrm{A}$ has the isotopic composition of PMM, but a different trace element composition. Elements more compatible than $\mathrm{Zr}$ ( $\mathrm{Y}$ and to a lesser extent $\mathrm{Ti}$-Pearce and Norry, 1979) are enriched in component A relative to $\mathrm{Zr}$, whereas elements that are more incompatible $(\mathrm{Nb}, \mathrm{Th}$, and $\mathrm{Pb})$ are depleted relative to $\mathrm{Zr}$. These characteristics suggest that component A represents suboceanic lithosphere which has lost a melt fraction during its previous history of upwelling at a mid-ocean ridge. An origin in another setting of oceanic volcanism cannot be ruled out, although the low contents of incompatible elements probably rule out an origin at an oceanic island, while the low contents of $\mathrm{Th}$ and $\mathrm{Pb}$ do not suggest an origin in an island arc. Such an interpretation is consistent with most models for boninite genesis, which require a depleted, lithospheric rather than fertile, asthenospheric mantle source (see papers in Crawford, 1989). Note that, if component $\mathrm{A}$ is suboceanic lithosphere, it would be expected to vary in composition with depth, becoming more depleted toward the Moho. This 

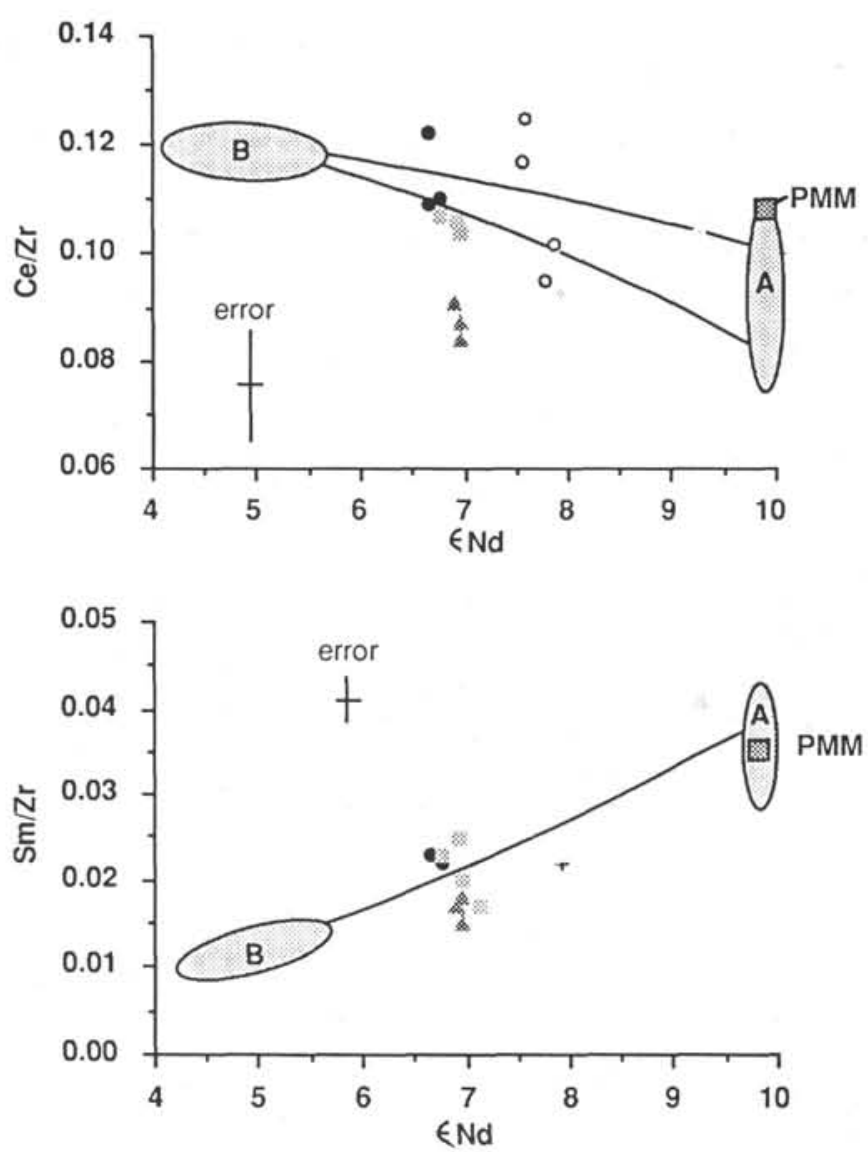

Figure 11. Plots of (A) Ce/Zr, (B) $\mathrm{Nd} / \mathrm{Zr}$, (C) $\mathrm{Sm} / \mathrm{Zr}$, and (D) $\mathrm{Yb} / \mathrm{Zr}$ against $\varepsilon$ Nd. $\mathrm{PMM}=$ Pacific MORB mantle. fields shown are approximate possible ranges for inferred components $\mathrm{A}$ and $\mathrm{B}$. Curved lines are mixing lines between these components assuming $\mathrm{Nd} / \mathrm{Zr}=0.12$ in component $\mathrm{A}$ and 0.06 in component $\mathrm{B}$. The key to the symbols is that given in Figure 10 .

is also a common consideration in boninite models (e.g., Stern et al., 1991). It is therefore quite probable that component A will vary in its trace element ratio according to which part of the lithosphere was melted. Isotopically it may also be variable, as even single ridge segments are known to exhibit small isotopic variations (e.g., White et al., 1987). The component has therefore been denoted by an ellipse rather than a point in Figure 10, and mixing lines have been drawn, where possible, for both fertile and refractory end-members of component $\mathrm{A}$.

Component $\mathrm{B}$ is characterized by low $\varepsilon \mathrm{Nd}$. Its isotopic composition cannot be determined directly, but the $\mathrm{Ti} / \mathrm{Zr}$ and $\mathrm{Y} / \mathrm{Zr}$ plots place constraints on the possible range of values. It is apparent from these plots that component $\mathrm{B}$ has low $\mathrm{Ti} / \mathrm{Zr}$ and $\mathrm{Y} / \mathrm{Zr}$ ratios and that any reasonable extrapolation of the mixing trend would intersect the horizontal axis at a value of $\varepsilon \mathrm{Nd}$ between about 3 and 5 . The precise value will depend on the curvature of the mixing trend and the exact composition of component $\mathrm{A}$. The $\varepsilon \mathrm{Nd}$ value of component $\mathrm{B}$ could lie anywhere between this intercept and the samples with lowest $\varepsilon \mathrm{Nd}$ (the LCB group), i.e., between about 4 and 6.5. We have assumed a mean value of +5 in Figure 10 but have presented the component as an ellipse with its long axis along the mixing curve. It is then apparent that component $\mathrm{B}$ has $\mathrm{Th} / \mathrm{Zr}$ and $\mathrm{Pb} / \mathrm{Zr}$ ratios significantly greater than $\mathrm{PMM}, \mathrm{a} \mathrm{Nb} / \mathrm{Zr}$ ratio less than PMM (but greater than component $\mathrm{A}$ ), and $\mathrm{Ti} / \mathrm{Zr}$ and $\mathrm{Y} / \mathrm{Zr}$ ratios significantly less than PMM.

The REEs also help to characterize component B, despite their mobility during alteration which has reduced the effective sample size and precluded the use of the most mobile element, La. Plots of four $\mathrm{REE} / \mathrm{Zr}$ ratios against $\mathrm{Nd}$ are presented in Figure 11. These are also
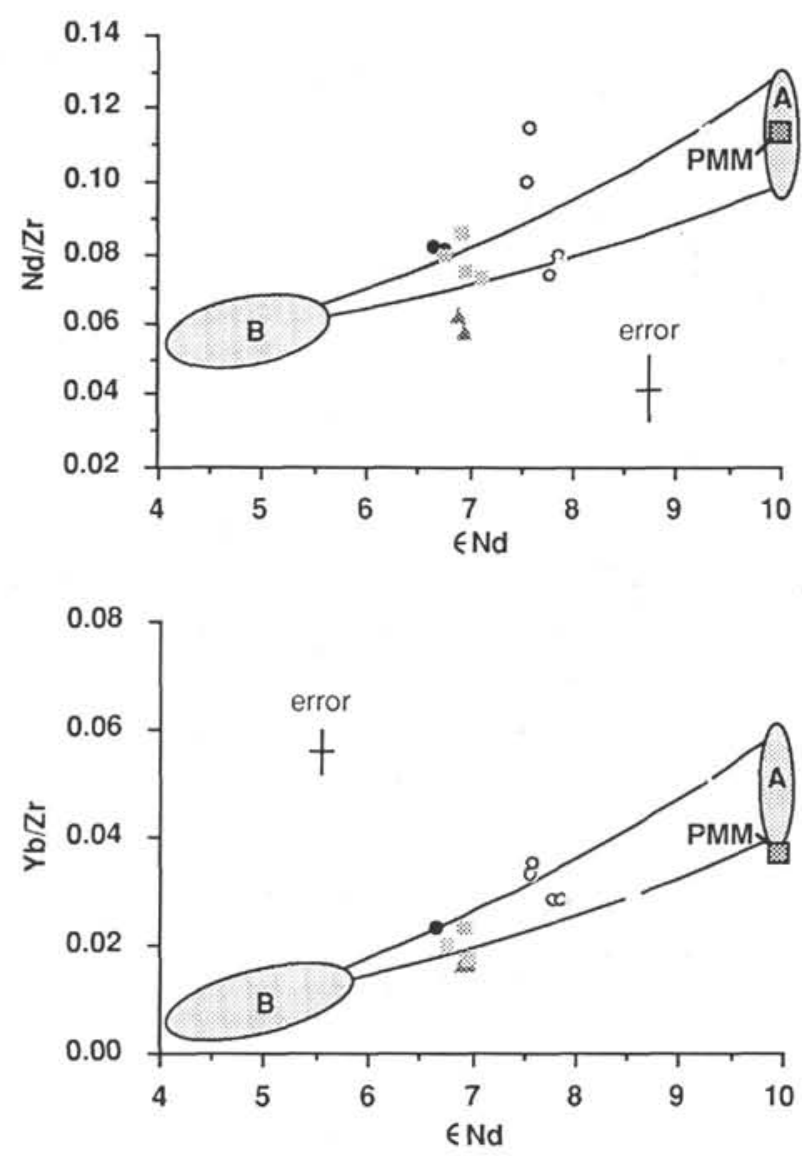

Figure 11 (continued).

consistent with a two-component mixing model. The $\mathrm{Ce} / \mathrm{Zr}$ ratio is unchanged within the large limits of alteration and experimental error, giving values of $0.8-1.2$ for components $\mathrm{A}$ and $\mathrm{B}$. $\mathrm{Nd}, \mathrm{Sm}$, and $\mathrm{Yb}$ all have lower ratios to $\mathrm{Zr}$ in component $\mathrm{B}$ compared with component $\mathrm{A}$. The $\mathrm{Sm} / \mathrm{Zr}$ ratio is particularly significant. $\mathrm{Sm}$ and $\mathrm{Zr}$ are generally regarded as exhibiting similar petrogenetic behavior, and are often placed adjacent to each other in multi-element patterns (Wood, 1979; Pearce, 1983; Thompson et al., 1983). The fact that component $\mathrm{A}$ has a similar $\mathrm{Sm} / \mathrm{Zr}$ ratio to PMM in Figure 11 is consistent with the similarity in petrogenetic behavior of these two elements. Several authors have noted that boninites commonly have positive $\mathrm{Zr}$ anomalies on these patterns (Sun and Nesbitt, 1978; Cameron et al., 1983; Hickey-Vargas, 1989; Murton et al., this volume). It is apparent from this diagram that component $\mathrm{B}$, if a global feature, could be the cause of these anomalies. The nature of component B is not, however, immediately obvious and it is therefore discussed in more detail in the next section.

A further point to emerge from these figures is the spread of trace element ratios across the mixing trends. This may in part be caused by experimental error. However, it is also a predictable consequence of mixing between a variable component $\mathrm{A}$ (from more fertile to more refractory lithosphere) and a single component B. A given mass fraction of component B will have a much greater effect on the composition of depleted mantle lithosphere than on the composition of more fertile mantle lithosphere. The fact that the low-Ca boninite group tends to plot with slightly lower $\varepsilon \mathrm{Nd}$ values coupled with slightly higher ratios of $\mathrm{Y} / \mathrm{Zr}$ and lower ratios of $\mathrm{Nb} / \mathrm{Zr}$ and $\mathrm{Th} / \mathrm{Zr}$ compared to the intermediate-Ca boninite group, may therefore suggest derivation from the more refractory lithosphere. Note, however, that partial melting and alteration will also contribute to these variations. These ideas are developed further in the light of other lines of evidence in the synthesis chapter (Pearce et al., this volume). 

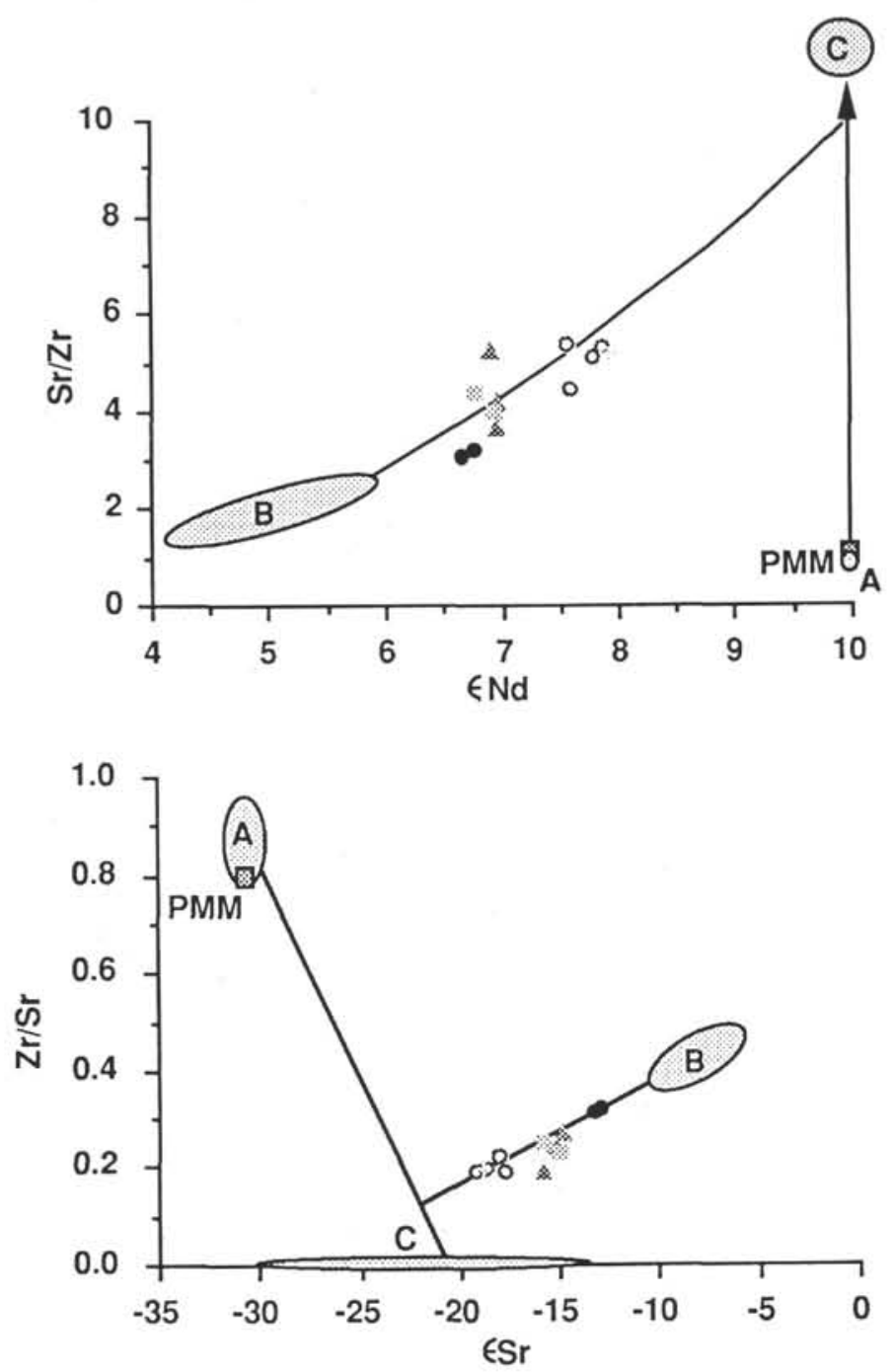

Figure 12. Plots of (A) $\mathrm{Sr} / \mathrm{Zr}$ against $\varepsilon N d$ and $(\mathbf{B}) \mathrm{Zr} / \mathrm{Sr}$ against $\varepsilon$ Sr showing the additional component, $\mathrm{C}$. Mixing lines assume $\mathrm{Zr} / \mathrm{Sr}=0.85$ in component A, 0.4 in component $B$, and 0 in component $C$. The details otherwise are those given in Figures 10 and 11.

All the elements so far plotted can be interpreted in terms of a simple two-component mixing model. $\mathrm{Sr}$ is a notable exception, as shown in Figure $12 \mathrm{~A}$. The diagram $\mathrm{Sr} / \mathrm{Zr}$ vs. $\varepsilon \mathrm{Nd}$ gives a mixing trend for the boninites but intersects the $\varepsilon \mathrm{Nd}=10$ line at very high $\mathrm{Sr} / \mathrm{Zr}$ ratios, of at least 10 . The tholeiites may follow a similar trend but intersect the $\varepsilon \mathrm{Nd}$ $=10$ line at a value of about 5 . By contrast, $\mathrm{PMM}$ has a $\mathrm{Sr} / \mathrm{Zr}$ ratio of about 1. Moreover, this ratio should be even lower in suboceanic lithosphere because $\mathrm{Sr}$ is more incompatible than $\mathrm{Zr}$ during MORB genesis. The simplest explanation is that a third component, carrying $\mathrm{Sr}$ but not the REE, Th, $\mathrm{Pb}, \mathrm{Ti}, \mathrm{Zr}$, Y, or $\mathrm{Nb}$, has increased the $\mathrm{Sr} / \mathrm{Zr}$ ratio. The most obvious source of this component is an aqueous phase derived from a subduction zone. This component, termed $\mathrm{C}$, has been depicted on the diagram as an arrow to very high $\mathrm{Sr} / \mathrm{Zr}$ ratios.

An equivalent diagram of $\varepsilon \mathrm{Sr}$ against $\mathrm{Zr} / \mathrm{Sr}$ ratio has also been plotted in Figure 12B to define this component more clearly. The compositional ranges for components $\mathrm{A}$ and $\mathrm{B}$ have been constrained by Figure 5 and Figure 12A. Figure 12B then constrains component $\mathrm{C}$ to very low $\mathrm{Zr} / \mathrm{Sr}$ ratios but also to low $\varepsilon \mathrm{Sr}$ values of between about -25 and -20 . Thus, if this component were a fluid derived from subducted crust, it could not have been displaced far from the original crustal composition. In other words, the strontium released contains a large crustal component but only a small seawater component. This is explicable if the subducted crust were young, as it would then carry little sediment and have experienced little oxidative alteration. It is also explicable if the fluid were derived from serpentinite dehydration, as $\mathrm{Sr}$ would then have been extracted primarily from the relatively unaltered crustal rocks.

Figure 12 also shows that the tholeiites from Hole 782 and the basaltic andesite from Hole 786A have changed their order on the mixing trend when $\varepsilon \mathrm{Sr}$ is used as the horizontal axis. On mixing lines based on $\varepsilon \mathrm{Nd}$ and $\mathrm{Pb}$ isotope ratios, they plot closest to PMM. On mixing lines based on $\varepsilon \mathrm{Sr}$ values, they are intermediate between the two boninite groups (the $41 \mathrm{Ma}$ boninitic edifice, and the late dikes from Hole 786B plus the lavas from Hole 786A). The geometry of Figure $12 \mathrm{~B}$ requires that the order can only change if component $\mathrm{C}$ is more radiogenic in the tholeiites than in the boninites. The fact that the tholeiites lie off the boninite trend in Figure 12A further suggests that the tholeiites differ from the boninites in their interaction with the high-Sr component.

It may be particularly significant that the mixing trend lies in the direction of component B in the diagrams on Figure 12. This would be the expected trend if component $\mathrm{C}$ were added to the mantle lithosphere (A) before component $\mathrm{B}$. If component $\mathrm{B}$ were added to the mantle lithosphere before component $\mathrm{A}$, an apparent trend could result by mixing exactly the right proportions of component $\mathrm{C}$ to a variable mixture of components A and B. This option cannot be ruled out at this stage, although it must be regarded as having a lower probability.

The average compositions of components $\mathrm{A}-\mathrm{C}$ can be read off the plots in Figures $10-12$ as element/Zr ratios. These are presented in pattern form in Figure 13 as the element $/ \mathrm{Zr}$ ratio in the component normalized to the element $/ \mathrm{Zr}$ ratio in PMM. Note that there are no constraints on the absolute $\mathrm{Zr}$ concentrations (and hence the absolute concentrations of other elements) in these components. PMM itself forms a straight line on these plots, its position depending on these $\mathrm{Zr}$ concentrations. PMM reference lines have been drawn for $\mathrm{Zr}$ contents of $11 \mathrm{ppm}$ in PMM, $4 \mathrm{ppm}$ in component $\mathrm{A}$, and $100 \mathrm{ppm}$ in component $\mathrm{B}$. The pattern for component $\mathrm{A}$ is comparable to that expected for suboceanic lithosphere that has lost a small melt fraction, as discussed above. The pattern for component $\mathrm{C}$ is comparable to that expected for a slab dehydration component carrying only the most mobile large-ion lithophile (LIL) elements. The pattern for component $\mathrm{B}$ is characterized by high contents of $\mathrm{Pb}$, Th and $\mathrm{Sr}$, moderate contents of $\mathrm{Zr}, \mathrm{La}$, and $\mathrm{Ce}$, lower contents of $\mathrm{Ce}-\mathrm{Sm}$, and low contents of M-HREE, Y, and Ti. Component B is quite distinct from most components conventionally considered to be involved in magma genesis and is investigated further below.

Figure 14 compares the trends followed by Leg 125 samples on three of the diagrams with those followed by the Mariana arc (Lin et al., 1989, 1990; Bloomer et al., 1989), Mariana Trough (Stern et al., 1990; Volpe et al., 1987, 1990; Hawkins et al., 1990) and Sumisu Rift (Hochstaedter et al., 1990). It is apparent that the present-day Mariana-Bonin arc-basin system is characterized by $\mathrm{Ti} / \mathrm{Zr}$ and $\mathrm{Sm} / \mathrm{Zr}$ ratios that remain constant or increase as the compositions become more radiogenic, rather than decrease as in the Leg 125 samples. On the plot of $\mathrm{Sr} / \mathrm{Zr}$ against $\varepsilon \mathrm{Sr}$, the rocks from the extant arc basin system form a simple two-component mixing line between PMM and a radiogenic component with a high $\mathrm{Sr} / \mathrm{Zr}$ ratio. The nature of the components in the active Mariana arc-basin system has been discussed in some detail by the authors cited above. They consider three components: a MORB-mantle; a subduction component that has metasomatized this MORB mantle; and an ocean island basalt (OIB) type mantle that might represent "trapped" lithosphere. Clearly, there is no similarity between these components involved in present arc-magmatism in the Izu-Bonin region and the components involved in Eocene forearc magma genesis at Sites 782 or 786 .

The nature of component $\mathrm{B}$ can also be investigated by comparing the same isotope-trace element plots for the Leg 125 lavas with those for Pacific hotspots and ridges (Fig. 15). Data plotted are taken from 

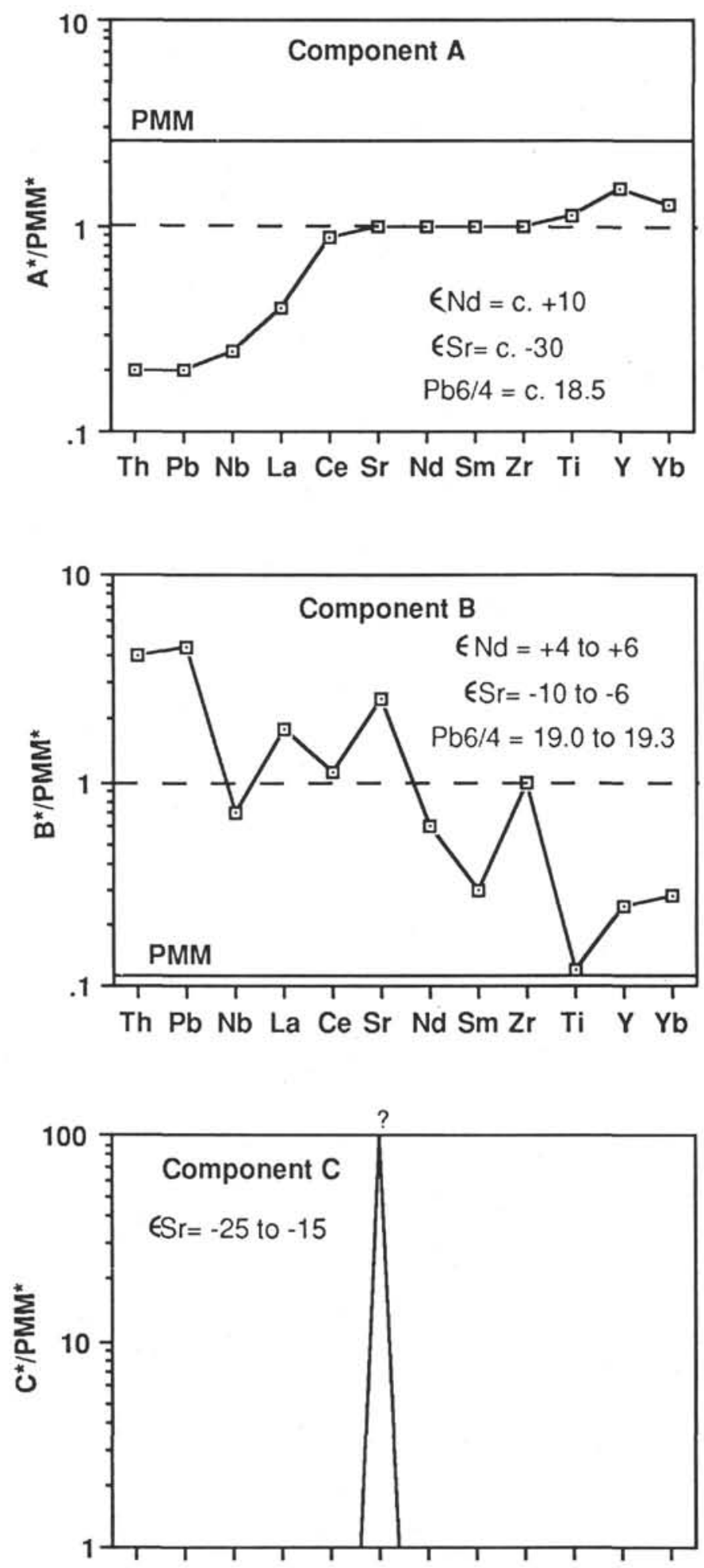

Figure 13. Trace element patterns and isotopic composition for the three components inferred for the Leg 125 boninites and tholeiites. A*, B* and $\mathrm{C}^{*}$ refer to the ratios of elements to $\mathrm{Zr}$ in the three components. $\mathrm{PMM}^{*}$ refers to the ratios of elements to $\mathrm{Zr}$ in Pacific MORB Mantle (PMM). Compositions of components $\mathrm{A}$ and $\mathrm{B}$ are taken from Figures 10 and 11.
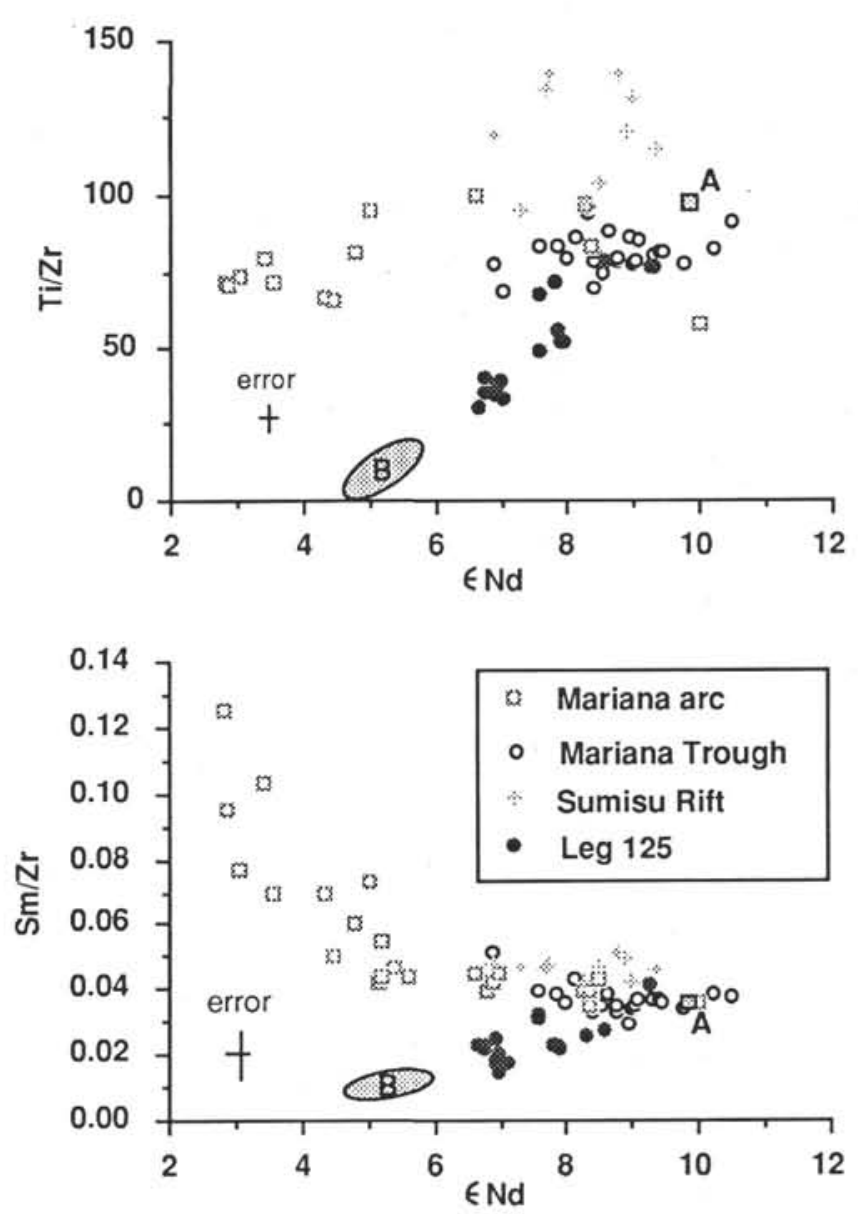

Figure 14. Plots of $\mathrm{Ti} / \mathrm{Zr}$ and $\mathrm{Sm} / \mathrm{Zr}$ against $\varepsilon$ ND showing the contrast between the Leg 125 boninites and tholeiites and subduction-related lavas from the present-day Mariana/Volcano arcs, Mariana Trough and Sumisu Rift. See text for data sources. Compositions of components $\mathrm{A}$ and $\mathrm{B}$ are taken from Figures 10 and 11.

East Pacific Rise off-axis seamounts (Zindler et al., 1984), Hawaii (Chen and Frey, 1985; Staudigel et al., 1984), and the Caroline islands (Dixon et al., 1984). All these data plot on trends of constant or increasing $\mathrm{Ti} / \mathrm{Zr}$ and $\mathrm{Sm} / \mathrm{Zr}$ ratio, again showing no evidence for a component of the type seen in the boninites. Thus, although papers on boninites frequently refer to "OIB components," there is no evidence that such a component was involved in the genesis of the Leg 125 boninites.

One key question in understanding component B is how to fractionate both the $\mathrm{Ti} / \mathrm{Zr}$ and $\mathrm{Sm} / \mathrm{Zr}$ ratios. This question is discussed in more detail elsewhere (Pearce et al., this volume). The main possibilities are partial melting, a subduction component, and an asthenospheric (OIB) component. If these ratios are to be fractionated during partial melting, it is most unlikely that this could be accomplished by minor phases such as zircon and REE-phases, both of which are soluble in basic melts at mantle temperatures (e.g., Watson and Harrison, 1984). The only phase that might do this is amphibole, which would retain $\mathrm{Ti}$ and $\mathrm{Sm}$ relative to $\mathrm{Zr}$. In a partial melting model the low-Ca boninites and intermediate- $\mathrm{Ca}$ boninites would have to retain the most amphibole in their residues to explain their high $\mathrm{Zr} / \mathrm{Sm}$ ratios. This scenario is not consistent with the 
scarcity of amphibole in the residual peridotites recovered from the forearc (Ishii and Robinson, this volume), nor with the fact that trace element fractionation is accompanied by isotopic variations.

In the models requiring subduction zone enrichment, melting rather than dehydration must be invoked to mobilize $\mathrm{Zr}$ and residual amphibole must be present to fractionate $\mathrm{Zr}$ from the M-HREE (residual zircon would fractionate these elements, but deplete, rather than enrich, $\mathrm{Zr}$ in the melt). Melting of hydrated oceanic crust in amphibolite facies is the simplest explanation. Many tonalitic and trondhjemitic intrusions, and andesite-rhyolite lavas, most notably in the Archaean (e.g., De Wit et al., 1987; Drummond and Defant, in press) but also in ophiolites (Pedersen and Malpas, 1984) and young volcanic arcs (Defant and Drummond, in press) have been interpreted as partial melts of amphibolite. They typically have $\mathrm{Zr} / \mathrm{Y}$ ratios of 20 or more and $\mathrm{Zr} / \mathrm{Sm}$ ratios of 60 or more, which would explain the trends in Figure 10. Moreover, amphibolite melting has been observed in metamorphic soles beneath ophiolitic slabs (e.g., Pearce, 1989) and subduction zone metamorphic terranes (Sorensen, 1988). Note, however, that component B is more radiogenic than PMM. This model would not, therefore be consistent with fusion of normal oceanic crust, but would fit the fusion of volcanogenic sediments or of transitional oceanic crust.

The third option, metasomatism by an asthenospheric melt, was proposed by Hickey-Vargas (1989), who was one of the first to stress the importance of high $\mathrm{Zr} / \mathrm{Sm}$ ratios in boninites. Although Figure 15 demonstrated that this option fails to explain the unusual fractionation of $\mathrm{Zr}$ from $\mathrm{Sm}$, an asthenospheric melt which had equilibrated with amphibole could achieve the required fractionation. One possible scenario is during ridge subduction, where asthenospheric fluids could penetrate the "slab window" and interact with a mantle wedge containing amphibole-bearing peridotite. In this case, the chromatographic effect, applied to the mantle wedge by Navon and Stolper (1987) and to the genesis of boninites in particular by Stern et al. (1991), may have a significant effect on isotope as well as trace element ratios. These scenarios are depicted in schematic form in Figure 16 and a more detailed discussion is carried out in the synthesis chapter (Pearce et al., this volume). It must be emphasized, however, that these and other options require further examination before any rigorous tectonic model can be developed.

\section{REGIONAL VARIATIONS IN ISOTOPE COMPOSITION}

The boninites of Leg 125 are the latest in a series of EoceneOligocene terranes from the Izu-Bonin-Mariana region that have been analyzed isotopically. These terranes comprise:

1. The West Philippine Basin (Meijer, 1975)

2. Chichijima (Hickey and Frey, 1982; Cameron et al., 1983; Dobson and Tilton, 1989, Karpenko et al., 1985)

3. Guam (Meijer, 1976; Hickey-Vargas and Reagan, 1987)

4. Saipan (Meijer, 1983)

5. DSDP Leg 60 (Mariana forearc) (Hickey-Vargas, 1989)

6. The Mariana inner trench wall (Stern et al., 1991)

The interpretation of these data, and their implications for the understanding of the Eocene-Oligocene crustal accretion in this part of the Western Pacific, has already been covered in depth by the above authors. The range of magma types recovered by Leg 125 does, however, greatly extend the forearc data base so that further discussion is worthwhile. Our aim in this section is to examine the regional implications of the Leg 125 isotope data.

Lead isotope plots are generally regarded as most informative. Figure 17 shows a plot of ${ }^{208} \mathrm{~Pb} /{ }^{204} \mathrm{~Pb}$ isotope ratios relative to the ${ }^{206} \mathrm{~Pb} /{ }^{204} \mathrm{~Pb}$ for Leg 125 samples in the context of the regional data. Figure 17A addresses the question of the origin of the suboceanic lithosphere in the Izu-Bonin region (component A). It is generally held (e.g., Meijer, 1980; Hickey-Vargas, 1989) that subduction began at a transform margin to the present West Philippine Basin, and that West Philippine Basin suboceanic lithosphere, hydrated and further
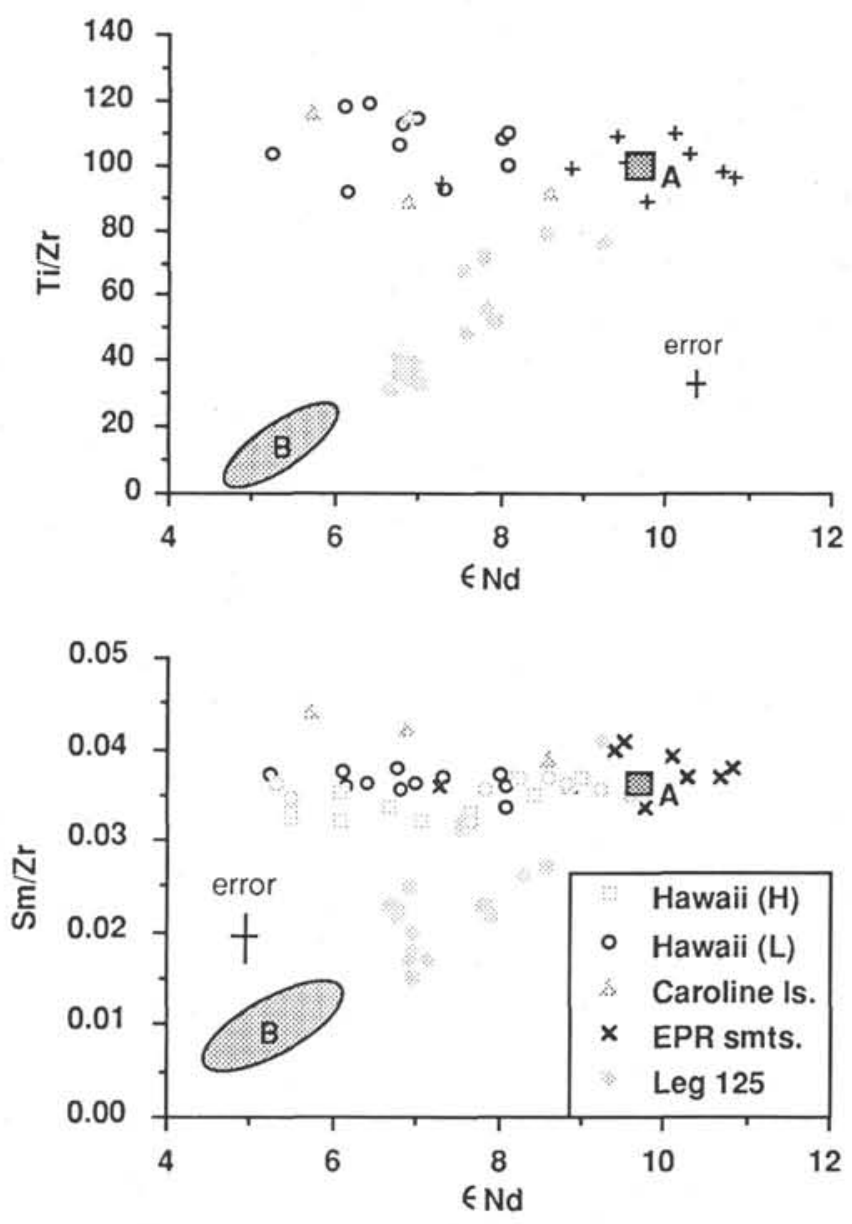

Figure 15. Plots of $\mathrm{Ti} / \mathrm{Zr}$ and $\mathrm{Sm} / \mathrm{Zr}$ against $\varepsilon N d$ showing the contrast between the Leg 125 boninites and ridge and hotspot-related lavas from the East Pacific Rise seamounts, Hawaii ( $\mathrm{L}=\mathrm{Loihi} ; \mathrm{H}=$ Haleakala) and Caroline islands. See text for data sources. Compositions of components A and B are taken from Figures 10 and 11.

metasomatized from an incipient subduction zone, is the source of most Eocene and Oligocene boninites from the region. However, Figure 17A shows that the West Philippine Basin gives a trend parallel to the NHRL, but displaced to higher ${ }^{208} \mathrm{~Pb} /{ }^{204} \mathrm{~Pb}$ ratios. Moreover, $\mathrm{Sr}$ isotope data from dredged and drilled basement samples from the Philippine Sea (Matsuda, 1985) give values in excess of MORB (on the order of $0.7038 \pm 4$ ), again suggesting that the Philippine Sea lithosphere is unlikely to be related to PMM and hence is unlikely to represent component A in the genesis of Leg 125 samples. Mariana Trough data, plotted for comparison, form a trend between the Philippine Sea and the Leg 125 samples. They also cannot obviously be related to the genesis of the Eocene-Oligocene lavas and dikes. We can therefore infer that the $\mathrm{Pb}$ in the Leg 125 samples was probably derived from Pacific lithosphere located east of the West Philippine Basin in the Eocene and Oligocene.

Figure 17B compares Leg 125 data with data from other Western Pacific boninites of comparable age. On this diagram, the DSDPLeg 60 samples, boninites from the inner trench wall and the Facpi group from Guam most resemble the Eocene-Oligocene samples from Leg 125. All plot close to the NHRL with a similar range of lead isotope ratios. The tholeiitic andesite and dacite from Site 782 and the tholeiites from DSDP Leg 60 also plot on or near the NHRL but at lower lead isotope ratios. The tholeiitic suites from the Alutom group on Guam and andesitesrhyolites on Saipan have still lower radiogenic lead isotope ratios. This distribution of Eocene-Oligocene data along the NHRL, indicating an 

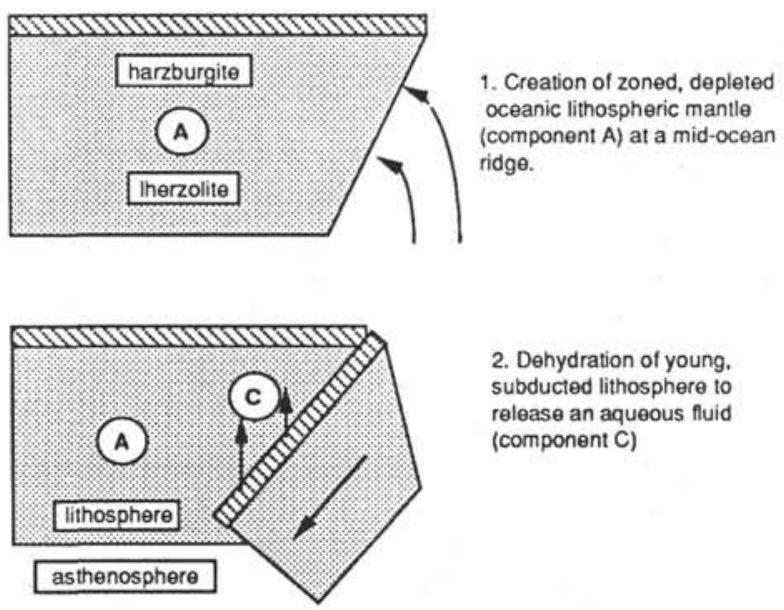

2. Dehydration of young. subducted lithosphere to release an aqueous fluid (component C)

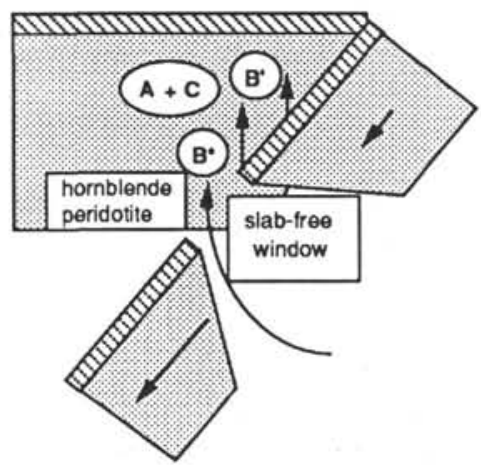

3. Partial melting of subducted crust to give a tonalitic melt (component B') or chromatographic fractionation of asthenospheric melt (component $\mathbf{B}^{*}$ ). Amphibole is invoked in both cases to fractionate the $\mathrm{Sm} / \mathrm{Zr}$ and $\mathrm{Ti} / \mathrm{Zr}$ ratios.

Figure 16. Schematic representation of a possible tectonic explanation for the isotopic components in Leg 125 lavas. Note that other scenarios involving hot-hot subduction are also possible. For a more detailed discussion of the tectonic options, see Pearce et al. (this volume).

absence of subducted sediment lead in the mantle source, was noted by Hickey-Vargas (1989) who concluded that the subducted sediment signature was absent from pre-Miocene lavas from the Mariana arc-trench region. The exception is the lavas from Chichijima, which plot off the NHRL toward pelagic sediment compositions. The Chichijima lead iso-tope distribution was discussed by Dobson and Tilton (1989) who concluded that several percent of subducted sediment are required to explain the ${ }^{208} \mathrm{~Pb} /{ }^{204} \mathrm{~Pb}$ displacement.

Figure 18 compares the Leg 125 samples with the other Western Pacific Eocene-Oligocene terranes on the basis of three of the isotopetrace element ratio diagrams modeled in this paper. The additional pelagic sediment component in the Chichijima samples is clearly shown by the trend to low $\varepsilon \mathrm{Nd}$ values. This component, labelled " $\mathrm{D}$," could represent sediment subducted during the Eocene or have been a long-lived characteristic of the lithosphere in that region. The other terranes would plot within a triangle made up of components $\mathrm{A}, \mathrm{B}$, and $\mathrm{C}$ as defined by Leg 125 data. However, the proportions and precise compositions of these components cannot be ascertained without further work throughout the Westem Pacific boninite province.

\section{CONCLUSIONS}

\section{Summary of Interpretations Based on Isotope Covariations}

1. The Eocene-Oligocene samples all plot between depleted Pacific MORB mantle (PMM) and Pacific Volcanogenic Sediment
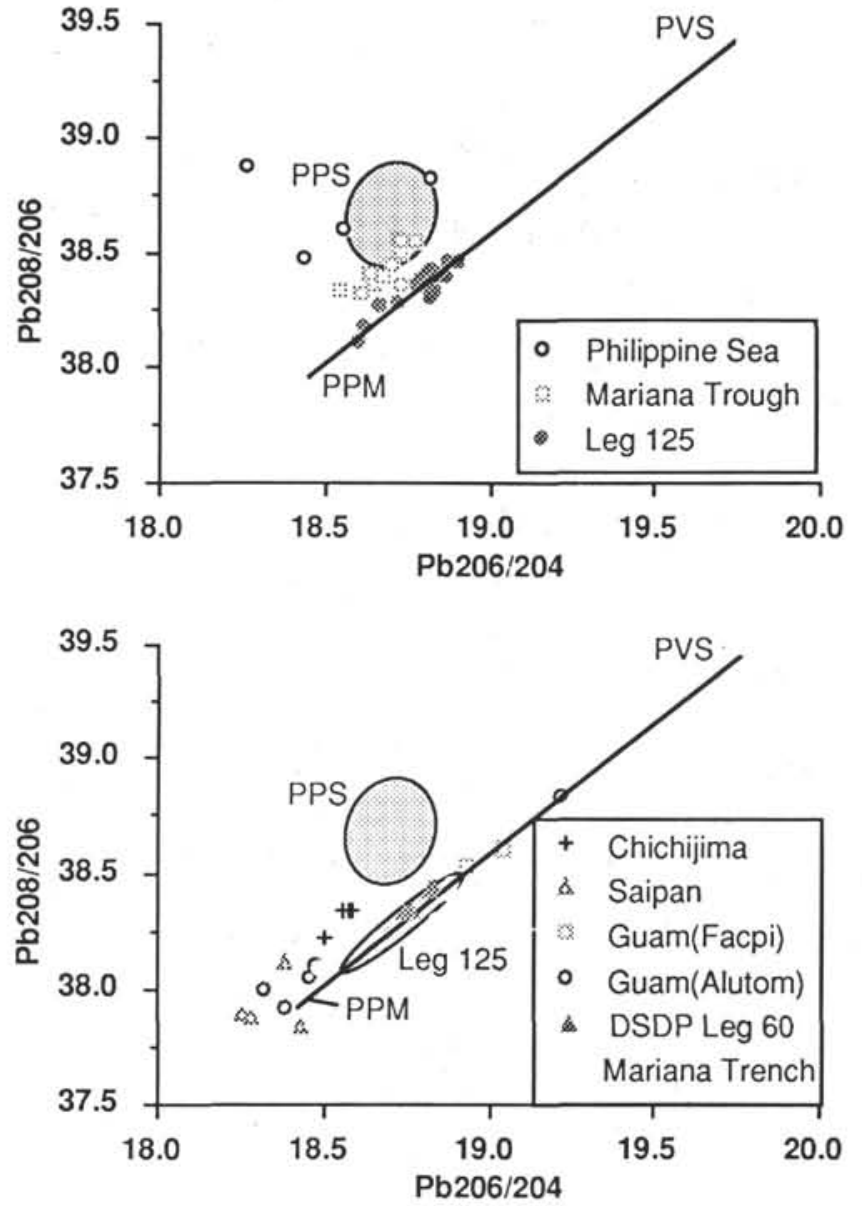

Figure 17. $\mathrm{Pb}$ isotope diagram showing the Leg 125 Eocene-Oligocene lavas in the context of $(\mathbf{A})$ regional ridge basalts and $(\mathbf{B})$ regional boninites and related rocks. PPS $=$ Pacific Pelagic Sediment; PVS $=$ Pacific Volcanogenic Sediment; $P P M=$ Pacific MORB Mantle. See the text for data sources.

(PVS) (i.e., along a Northern Hemisphere mantle array) in $\mathrm{Pb}-\mathrm{Nd}$ isotope space. There is no evidence of subducted pelagic sediment in the sources of these samples.

2. These samples also plot parallel to a line from PMM to PVS in $\mathrm{Sr}-\mathrm{Pb}$ and $\mathrm{Sr}-\mathrm{Nd}$ isotope space, but displaced to higher $\varepsilon \mathrm{Sr}$ values.

3. Isotope ratios indicate possible petrogenic links between (1) the low-Ca boninites and low-Ca bronzite andesites from the base of Hole 786B; (2) the intermediate-Ca boninites, intermediate-Ca bronzite andesites, andesites, dacites, and rhyolites from Hole 786B; (3) the late boninite dikes from Hole $786 \mathrm{~B}$ and the boninite clasts from Hole 786A; (4) the tholeiitic andesites, dacites, and rhyolites from Site 782. The basaltic andesite clast from Core $6 \mathrm{X}-5$ in Hole $786 \mathrm{~A}$ has a distinctly different composition.

3. The young basaltic andesites from Hole 786A plot on trends toward subducted sediments on $\mathrm{Pb}$ isotope diagrams, but this is as likely to be the result of interaction with sedimentary pore fluids as it is to have been caused by the presence of any subducted pelagic sediment in their source regions.

4. Within the Eocene-Oligocene samples, there is a systematic variation along the Northern Hemisphere mantle array, with the low-Ca boninite group showing most displacement, followed by the medium-Ca boninite group, then the high-Ca boninite group, and the tholeiites from Site 782 plotting closest to PMM. 

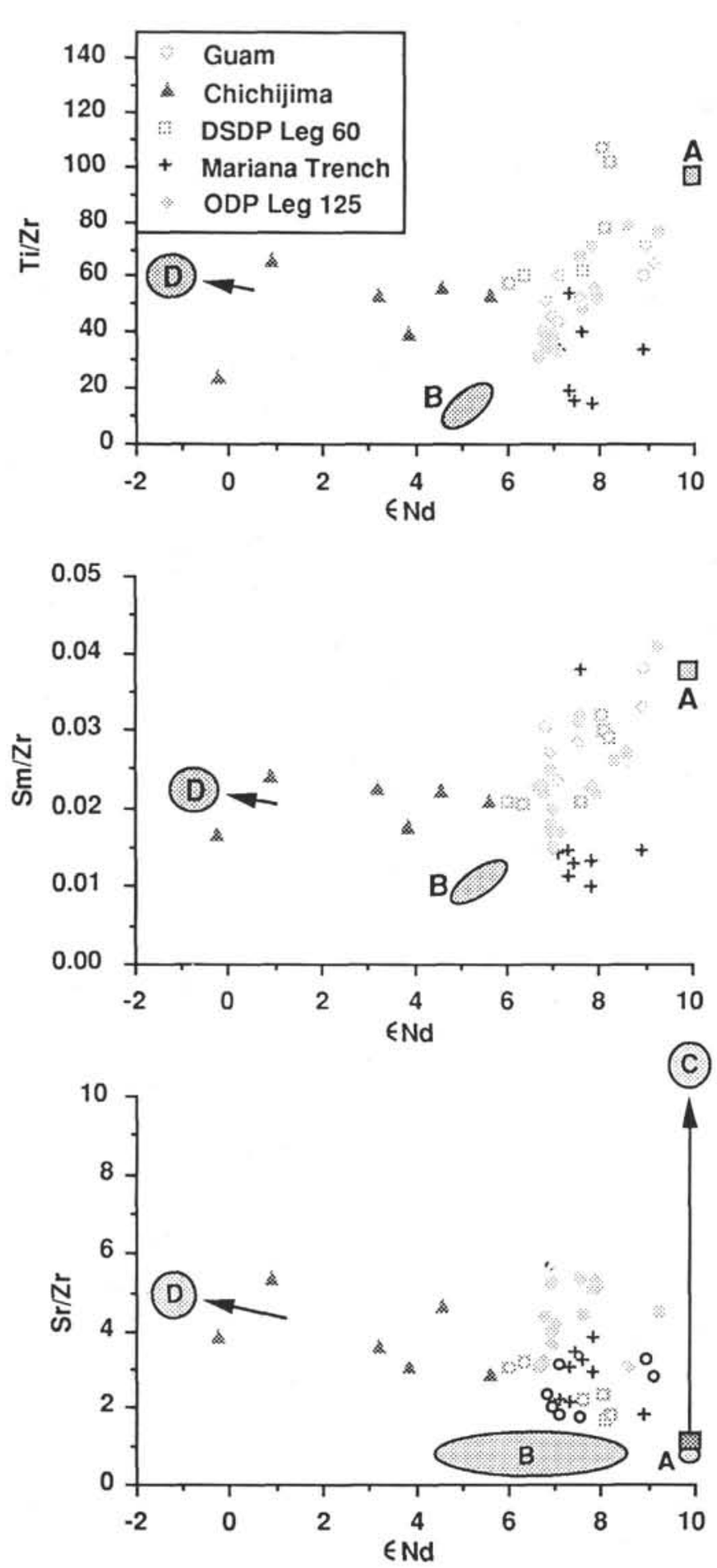

Figure 18. Plots of $\mathrm{Ti} / \mathrm{Zr}, \mathrm{Sm} / \mathrm{Zr}$, and $\mathrm{Sr} / \mathrm{Zr}$ against $\varepsilon \mathrm{Nd}$ for Leg 125 samples compared with regional boninites and related rocks. See Figures 10-12 for details of terms used. See text for data sources.

\section{Summary of Interpretations Based on Isotope-Trace Element Diagrams}

1. Much of the observed variation can be explained by the mixing of three components $(\mathrm{A}-\mathrm{C})$.

2. Component $\mathrm{A}$ has an isotopic composition close to PMM, but its trace element composition is characterized by high ratios of $\mathrm{Yb} / \mathrm{Zr}$ and $\mathrm{Y} / \mathrm{Zr}$ and low ratios of $\mathrm{Nb} / \mathrm{Zr}, \mathrm{Th} / \mathrm{Zr}$ and $\mathrm{Pb} / \mathrm{Zr}$. It is interpreted as suboceanic lithosphere that has lost a melt fraction during its earlier history at a mid-ocean ridge. This component is likely to have a variable trace element composition according to the degree of depletion of the lithosphere, and hence the depth at which melting takes place.

3. Component B has an isotopic composition closer to PVS with $\varepsilon \mathrm{Sr}$ of -10 to $-6, \varepsilon \mathrm{Nd}$ of 6 to 4 , and ${ }^{206} \mathrm{~Pb} /{ }^{204} \mathrm{~Pb}$ of 19.0 to 19.3 . It is characterized by low ratios of $\mathrm{Ti} / \mathrm{Zr}, \mathrm{Y} / \mathrm{Zr}$, and $\mathrm{Sm} / \mathrm{Zr}$ and high ratios of $\mathrm{Th} / \mathrm{Zr}$. These ratios are quite different from any known subduction or asthenospheric component presently involved in magma genesis in the Western Pacific. It can be explained in terms of a melt that has fractionated the above ratios by equilibration with amphibole, but it is not clear at this stage whether this took place by fusion of the subducted slab or by chromatographic fractionation of normal asthenospheric melts.

4. Component $\mathrm{C}$ appears only to affect $\mathrm{Sr}$ (and perhaps other alkali and alkaline earth elements) and $\varepsilon \mathrm{Sr}$. It has an $\varepsilon$ Sr value of about -25 to -15 . It is tentatively interpreted as an aqueous fluid derived by dehydration of subducted oceanic crust. The mixing trends suggest that component $\mathrm{C}$ may be added to the suboceanic lithosphere (component $\mathrm{A}$ ) before component $\mathrm{B}$.

\section{Summary of Interpretations Based on Regional Variations}

1. The samples from Leg 125 resemble most other Eocene-Oligocene boninitic terranes in the Western Pacific in having no significant pelagic sediment component. Only lavas and dikes from Chichijima in the subaerial part of the Izu-Bonin outer-arc high exhibit a clear trend toward Pacific pelagic sediment on $\mathrm{a} \mathrm{Pb}$ isotope diagram.

2. Of all the analyzed samples from the Mariana and Izu-Bonin forearcs, the samples from Leg 125 most resemble isotopically the boninitic Eocene Facpi Unit on Guam and boninites and tholeiites from DSDP Leg 60 drill-sites in the Mariana forearc, all of which plot along the NHRL toward radiogenic $\mathrm{Pb}$ isotope ratios.

3. It is possible that the Mariana and Izu-Ogasawara forearcs were formed by a highly variable (in space and time) petrogenetic system involving, in varying degrees, suboceanic lithosphere, aqueous subduction fluids, a slab (amphibolite)-melt subduction component or asthenospheric melt component that had equilibrated with amphibole, and a pelagic sediment-derived subduction component. More work is required to test this assertion and to explain in detail the temporal and spatial variability within the forearc terrane.

\section{ACKNOWLEDGMENTS}

J.A.P. and B.J.M. thank the Natural Environment Research Council (U.K.) for an ODP Special Topics Research Grant (GR3/416). J.A.P. is grateful to Bob Jackson (University of Durham Industrial Research Laboratories) for assistance with the ICP-MS and Ceri Jenkins for assistance in the RHBNC isotope laboratory. The RHBNC isotope laboratory is a London University intercollegiate facility. R.J.A. and S.v.d.L. thank USSAC for logistic and analytical costs. We all greatly appreciate the shipboard contributions of Patty Fryer, Laura Stokking, and the other shipboard scientists, marine technicians, and crew of the JOIDES Resolution. Pamela Kempton and Chris Hawkesworth provided helpful reviews of an earlier version of the manuscript.

\section{REFERENCES}

Ben Othman, D., White, W. M., and Patchett, J., 1989. The geochemistry of marine sediments, island arc magma genesis and crust-mantle recycling. Earth Planet. Sci. Lett., 94:1-21.

Bloomer, S. H., Stern, R. J., Fisk, E., and Geschwind, C. H., 1989. Shoshonitic volcanism in the northern Mariana Arc. 1. Mineralogic and major and trace element characteristics. J. Geophys. Res., 94:4469-4496.

Cameron, W. E., McCulloch, M. T., and Walker, D. A., 1983. Boninite petrogenesis: chemical and $\mathrm{Nd}-\mathrm{Sr}$ isotopic constraints. Earth Planet. Sci. Lett., 65:75-89. 
Chen, C.Y., and Frey, F. A., 1985. Trace element and isotopic geochemistry of lavas from Haleakala volcano, East Maui, Hawaii: implications for the origin of Hawaiian basalts. J. Geophys. Res., 90:8743-8768.

Crawford, A. J. (Ed.), 1989. Boninites and Related Rocks: London (Unwin Hyman).

Defant, M. J., and Drummond, M. S., in press. Subducted lithosphere-derived andesitic and dacitic rocks in young volcanic arc settings. Nature.

De Wit, M. J., Armstrong, R., Hart, R. J., and Wilson, A. H., 1987. Felsic igneous rocks within the 3.3- to 3.5-Ga Barberton greenstone belt: high crustal level equivalents of the surrounding tonalite-trondhjemite terrane, emplaced during thrusting. Tectonics, 6:529-549.

Dixon, T. H., Batiza, R., Futa, K., and Martin, D., 1984. Petrochemistry, age and isotopic composition of alkali basalts from Ponape Island, Western Pacific. Chem. Geol., 43:1-28.

Dobson, P.F., and Tilton, G. R., 1989. Th, U and Pb systematics of boninite series volcanic rocks from Chichijima, Bonin Islands, Japan. In Crawford, A. J. (Ed.), Boninites and Related Rocks: London (Unwin Hyman), 396-415.

Dosso, L., and Murthy, V. R., 1980. A Nd isotopic study of the Kerguelen islands: inferences on enriched oceanic mantle sources. Earth Planet. Sci. Lett., 48:268-276.

Drummond, M. S., and Defant, M. J., in press. A model for trondhjemitetonalite-dacite genesis and crustal growth via slab melting: Archaean to modern comparisons. J. Geophys. Res.

Fryer, P., Pearce, J. A., Stokking, L. B., et al., 1990. Proc. ODP, Init. Repts., 125: College Station, TX (Ocean Drilling Program).

Hart, S. R., 1984. A large-scale isotope anomaly in the Southern hemisphere mantle. Nature, 309:753-757.

1988. Heterogeneous mantle domains: signatures, genesis and mixing chronologies. Earth Planet. Sci. Lett., 90:273-296.

Hawkesworth, C. J., 1982. Isotope characteristics of magmas erupted along destructive plate margins. In Thorpe, R. S. (Ed.), Andesites: New York (Wiley), 549-571.

Hawkesworth, C. J., and Norry, M. J. (Eds.), 1983. Continental Basalts and Mantle Xenoliths: Nantwich (Shiva).

Hawkins, J. W., Lonsdale, P. F., Macdougall, J. D., and Volpe, A. M., 1990. Petrology of the axial ridge of the Mariana Trough backarc spreading center. Earth Planet. Sci. Lett., 100:226-250.

Hickey, R. L., and Frey, F. A., 1982. Geochemical characteristics of boninite series volcanics: implications for their source. Geochim. Cosmochim. Acta, 46:2099-2115.

Hickey-Vargas, R. L., 1989. Boninites and tholeiites from DSDP Site 458, Mariana forearc. In Crawford, A. J. (Ed.), Boninites and Related Rocks: London (Unwin Hyman), 339-356.

Hickey-Vargas, R. L., and Reagan, M. K., 1987. Temporal variations of isotope and rare earth element abundances from Guam: implications for the evolution of the Mariana arc. Contrib. Mineral. Petrol., 97:497-508.

Hochstaedter, A. G., Gill, J. B., and Morris, J. D., 1990. Volcanism in the Sumisu Rift, II. Subduction and non-subduction components. Earth Planet. Sci. Lett. 100:195-209.

Karpenko, S. F., Sharaskin, A. Y., Balashov, Y. A., Lyalikov, A. V., and Spiridonov, V. G., 1985. Isotopic and geochemical criteria for the origin of boninites. Geochem. Int., 22:1-12.

Lin, P. N., Stern, R. J., and Bloomer, S. H., 1989. Shoshonitic volcanism in the northern Mariana arc, 2. Large-ion lithophile and rare earth element abundances: evidence for the source of incompatible element enrichments in intraoceanic arcs. J. Geophys. Res., 94:4497-4514.

Lin, P. N., Stern, R. J., Morris, J., and Bloomer, S. H., 1990. Nd- and Sr-isotopic compositions of lavas from the northern Mariana and southern volcano arcs: implications for the origin of island arc melts. Contrib. Mineral. Petrol., 105:381-392.

Meijer, A., 1975. $\mathrm{Pb}$ and $\mathrm{Sr}$ isotopic studies of igneous rocks cored during Leg 31 of the Deep Sea Drilling Project. In Karig, D. E., Ingle, J. C., Jr., et al., Init. Repts. DSDP, 31: Washington (U.S. Govt. Printing Office), 601-605. 1976. $\mathrm{Pb}$ and $\mathrm{Sr}$ isotopic data bearing on the origin of volcanic rocks from the Mariana arc system. Geol. Soc. Am. Bull., 87:1358-1369.

1980. Primitive arc volcanism and a boninitic series: examples from the Western Pacific island arcs. In Hayes, D. E. (Ed.), The Tectonic and Geological Evolution of Southeast Asian Seas and Islands. Am. Geophys. Union, Geophys. Monogr. Ser., 23:269-282.

1983. The origin of low-K rhyolites from the Mariana frontal arc Contrib. Mineral. Petrol., 83:45-51.
Matsuda, J., 1985. Sr isotopic studies of rocks from the Philippine Sea and some implication for mantle material. In Shiki, T. (Ed.), Geology of the Northern Philippine Sea: Tokyo (Tokai Univ. Press), 63-78.

Navon, O., and Stolper, E., 1987. Geochemical consequences of melt percolation: the upper mantle as a chromatographic column. J. Geol., 95:285-307.

Pearce, J. A., 1983. Role of the sub-continental lithosphere in magma genesis at active continental margins. In Hawkesworth, C. J., and Norry, M. J. (Eds.), Continental Basalts and Mantle Xenoliths: Nantwich (Shiva), 230-249.

1989. HT/P metamorphism and granite genesis beneath ophiolite thrust sheets. Ofioliti, 14:195-211.

Pearce, J. A., and Norry, M. J., 1979. Petrogenetic implications of Ti, Zr, Y and $\mathrm{Nb}$ variations in volcanic rocks. Contrib. Mineral. Petrol., 69:33-47.

Pedersen, R. B., and Malpas, J., 1984. The origin of oceanic plagiogranites from the Karmøy yophiolite, Western Norway. Contrib. Mineral. Petrol., 88:36-52.

Sorensen, S. S., 1988. Petrology of amphibolite-facies mafic and ultramafic rocks from the Catalina Schist, Southern California: metasomatism and migmatization in a subduction zone metamorphic setting. J. Metamorph. Geol., 6:405-435.

Staudigel, H., Zindler, A., Hart, S. R., Leslie, T., Chen, C.-Y., and Clague, D., 1984. The isotope systematics of a juvenile intraplate volcano: $\mathrm{Pb}, \mathrm{Nd}$, and $\mathrm{Sr}$ isotope ratios of basalts from Loihi Seamount, Hawaii. Earth Planet. Sci. Lett., 69:13-29.

Stern, R. J., Lin, P.-N., Morris, J. D., Jackson, M. C., Fryer, P., Bloomer, S. H., and Ito, E., 1990. Enriched back-arc basin basalts from the northern Mariana Trough: implications for the magmatic evolution of back-arc basins. Earth Planet. Sci. Lett., 100:210-225.

Stern, R. J., Morris, J., Bloomer, S. H., and Hawkins, J. W., 1991. The source of the subduction component in convergent margin magmas: trace element and radiogenic isotope evidence from Eocene boninites, Mariana forearc. Geochim. Cosmochim. Acta, 55:1467-1481.

Sun and Nesbitt, 1978. Geochemical regularities and genetic significance of ophiolitic basalts. Geology, 6:689-693.

Taylor, R. N., Lapierre, H., Vidal, P., Nesbitt, R. W., and Croudace, I. W., in press. Igneous geochemistry and petrogenesis of the Izu-Bonin forearc basin. In Taylor, B., Fujioka, K., et al., Proc. ODP, Sci. Results, 126: College Station, TX (Ocean Drilling program).

Thirlwall, M. F., 1991a. High-precision multicollector isotope analysis of low levels of Nd as oxide. Chem. Geol., 14:13-22.

1991b. Long term reproducibility of multicollector $\mathrm{Sr}$ and $\mathrm{Nd}$ isotope ratios. Chem. Geol., 14:85-104.

Thompson, R. N., Morrison, M. A., Dickin, A. P., and Hendry, G. L., 1983. Continental flood basalts ... Arachnids rule OK? In Hawkesworth, C. J., and Norry, M. J. (Eds.), Continental Basalts and Mantle Xenoliths: Nantwich (Shiva), 158-185.

Volpe, A. M., Macdougall, J. D., and Hawkins, J. W., 1987. Mariana Trough basalts (MTB): trace element and $\mathrm{Sr}$-Nd isotopic evidence for mixing between MORB-like and Arc-like melts. Earth Planet. Sci. Lett., 82:241-254.

Volpe, A. M., Macdougall, J. D., Lugmair, G. W., Hawkins, J. W., and Lonsdale, P., 1990. Fine-scale isotopic variation in Mariana Trough basalts: evidence for heterogeneity and a recycled component in back-arc mantle. Earth Planet. Sci. Lett., 100:251-264.

Watson, E. B., and Harrison, T. M., 1984. Accessory minerals and the geochemical evolution of crustal magmatic systems: a summary and prospectus of experimental approaches. Phys. Earth Planet. Int., 35:19-30.

White, W. M., Hofmann, A. W., and Puchelt, H., 1987. Isotope geochemistry of Pacific mid-ocean ridge basalt. J. Geophys. Res., 92:4881-4893.

Wood, D. A., 1979. A variably-veined suboceanic upper mantle-genetic significance for mid-ocean ridge basalts from geochemical evidence. Geology, 7:499-503.

Woodhead, J. D., 1989. Geochemistry of the Mariana arc (Western Pacific): source composition and processes. Chem. Geol., 76:1-24.

Zindler, A., and Hart, S., 1986. Chemical geodynamics. Ann. Rev. Earth Planet. Sci, 14:493-571.

Zindler, A., Staudigel, H., and Batiza, R., 1984. Isotope and trace element geochemistry of young Pacific seamounts: implications for the scale of upper mantle heterogeneity. Earth Planet. Sci. Lett., 70:175-195.

Date of initial receipt: 1 October 1990

Date of acceptance: 28 October 1991

Ms 125B-134 